\title{
INDICADORES DE DESEMPENHO DE FROTA DE EMPRESAS AGROINDUSTRIAIS CANAVIEIRAS BRASILEIRAS
}

\author{
Ricardo SoARes de Arruda Pinto
}

Dissertação apresentada à Escola Superior de Agricultura "Luiz de Queiroz", Universidade de São Paulo, para obtenção do título de Mestre em Agronomia, Área de Concentração: Máquinas Agrícolas

PIR A C I C A B A Estado de São Paulo - Brasil

Agosto - 2002 


\title{
INDICADORES DE DESEMPENHO DE FROTA DE EMPRESAS AGROINDUSTRIAIS CANAVIEIRAS BRASILEIRAS
}

\author{
Ricardo SoARES de ARRUdA Pinto \\ Engenheiro Agrícola e Administrador de Empresas
}

Orientador: Prof. Dr. TOMAZ CAETANO CANNAVAN RIPOLI

Dissertação apresentada à Escola Superior de Agricultura "Luiz de Queiroz", Universidade de São Paulo, para obtenção do título de Mestre em Agronomia, Área de Concentração: Máquinas Agrícolas

\author{
P I R A C I C A B A \\ Estado de São Paulo - Brasil
}

Agosto -2002 


\section{Dados Internacionais de Catalogação na Publicação (CIP)}

DIVISÃO DE BIBLIOTECA E DOCUMENTAÇÃO - ESALQ/USP

Pinto, Ricardo Soa res de Amuda
Indicadores de desempenho de frota de empresa sag roindustria is
canavieiras brasileira s / Ric ardo Soares de Amuda Pinto. - - Pira cic aba, 2002.

110 p. : il.

Dissertação (mestrado) - - Escola Superior de Agricultura Luiz de Queiroz, 2002.

Bibliografia.

1. Indústria açúca reira 2. Indústria a lc ooleira 3. Planejamento de transportes - Indicadores I. Título

CDD 631.11

"Permitida a cópia total ou parcial deste documento, desde que citada a fonte - $\mathrm{O}$ autor" 
Aos meus pais Maria José e Aureliano, de quem sempre muito recebi e por quem ainda pouco fiz,

à minha mulher Adriana que, do seu jeito especial, contribuiu muito para que pudesse realizar tanto este como outros projetos em minha vida,

aos meus filhos Camila, Luísa, Paula e André, que deixaram de ter muitos momentos de minha companhia, dividindo-me com minha pósgraduação,

aos meus irmãos Renata e Rogério e à minha sogra Iria, com quem completamos uma ótima família,

dedico este trabalho e, mais do que tudo, meu amor. 


\section{AGRADECIMENTOS}

Ao Prof. Dr. Tomaz Caetano C. Ripoli, pelo orientação impecável e irretorquível, pela motivação constante e pela amizade irrestrita.

Ao Adm. Reinaldo Antônio Kil, pelo auxílio e desenvolvimento conjunto do que viria a se tornar este trabalho, além da capacidade de prontamente contribuir com um amigo.

Ao Eng. Agr. Dib Nunes Jr. que, como sócio e amigo, contribuiu com o que pode para que eu pudesse terminar este trabalho.

À equipe do IDEA, minha empresa, que possibilitou que, de vez em quando, eu pudesse "sumir" para me dedicar à dissertação. 


\section{SUMÁRIO}

Página

LISTA DE FIGURAS ............................................................... viii

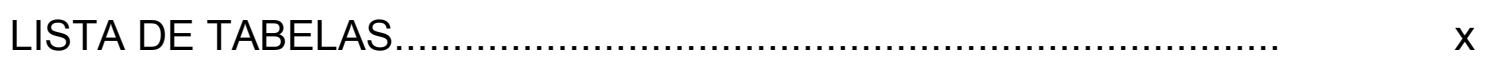

LISTA DE SIGLAS, ABREVIATURAS E SÍMBOLOS........................ xvi

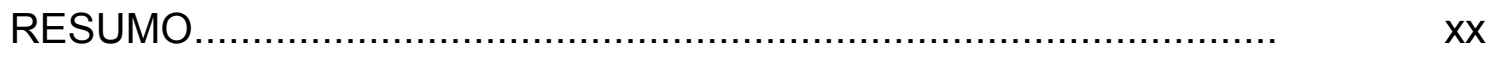

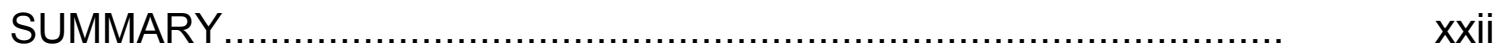

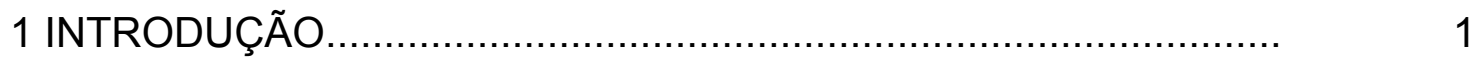

1.1 O problema e sua importância..................................................

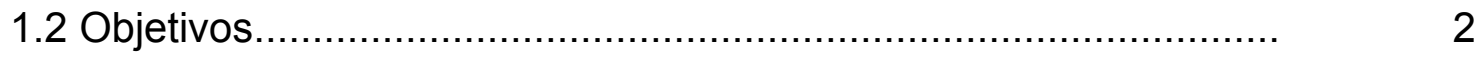

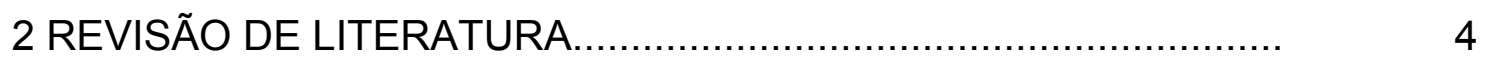

2.1 Gestão por indicadores......................................................

2.2 Emprego de indicadores......................................................

2.3 Mensuração de indicadores.................................................... 12

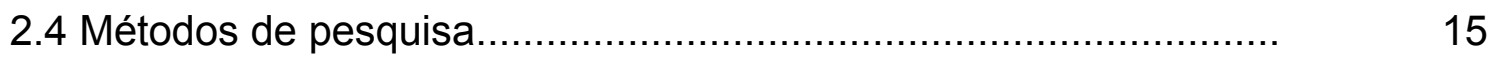

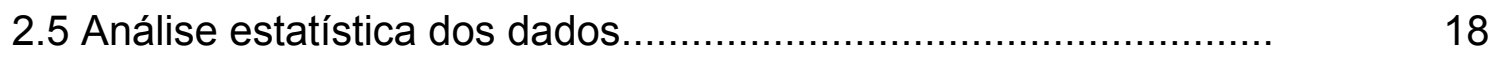

3 MATERIAL E MÉTODOS........................................................ 21

3.1 Proposição dos indicadores..................................................... 21 
3.1.1 Indicadores de avaliação de desempenho.................................. 22

3.1.1.1 Indicadores operacionais ................................................ 23

3.1.1.1.1 Produtividade média dos caminhões canavieiros - PMC...... 23

3.1.1.1.2 Cana carregada por carregadora por dia efetivo de safra CCD....................................................................... 24

3.1.1.1.3 Cana colhida por colhedora de cana por dia efetivo de safra - CPD...

3.1.1.1.4 Cana colhida por cortadora de cana inteira por dia efetivo de safra - CID

3.1.1.2 Indicador de dimensionamento........................................ 25

3.1.1.2.1 Equipamentos motorizados por $10^{3}$ ha de cana cortada EMC.

3.1.1.3 Indicadores de consumo de insumos......

3.1.1.3.1 Consumo de combustível ponderado por distância média - CDM.

3.1.1.3.2 Motores retificados no ano - MRA

3.1.2 Indicadores analítico-descritivos.

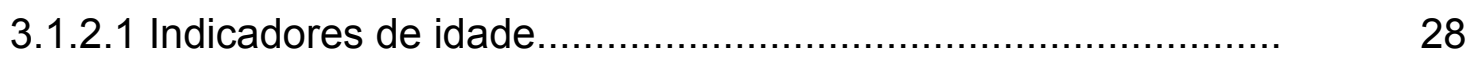

3.1.2.1.1 Idade média dos equipamentos automotrizes - IEA ............ 28

3.1.2.1.2 Idade média dos veículos - IVE........................................ 28

3.1.2.1.3 Idade média das máquinas - IMA..................................... 29

3.1.2.2 Indicadores de estratégia................................................... 29

3.1.2.2.1 Terceirização dos equipamentos motorizados - TMT........ 30

3.1.2.2.2 Plantio mecanizado de cana - PMN.................................. 30

3.1.2.2.3 Colheita mecanizada de cana - CMC................................ 31

3.2 Sistema de coleta de informações................................................ 31

3.2.1 Instrumento da coleta de dados......................................... 32

3.2.1.1 Teste piloto.................................................................

3.2.1.2 Envio do questionário....................................................... 33

3.3 Retorno dos resultados às agroindústrias canavieiras................... 33

3.4 Tratamento e análise dos dados................................................ 35

4 RESULTADOS E DISCUSSÃO.................................................. 


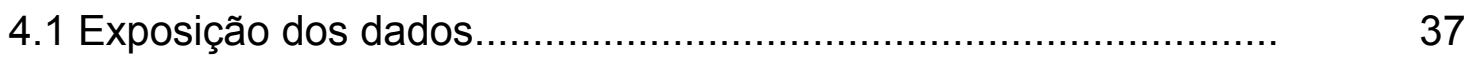

4.2 Representatividade das respostas aos questionários................... 37

4.3 Indicadores de avaliação de desempenho................................... 39

4.3.1 Indicadores operacionais...................................................... 39

4.3.1.1 Produtividade média dos caminhões canavieiros - PMC......... 39

4.3.1.2 Cana carregada por carregadora por dia efetivo de safra -

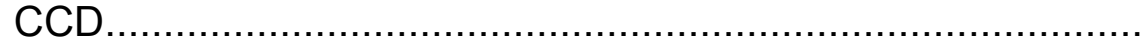

4.3.1.3 Cana colhida por colhedora de cana por dia efetivo de safra

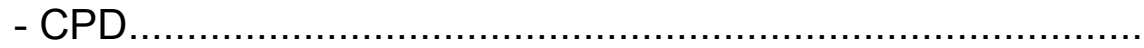

4.3.1.4 Cana colhida por cortadora de cana por dia efetivo de safra CID.

4.3.2 Indicador de dimensionamento.

4.3.2.1 Equipamentos motorizados por $10^{3}$ ha de cana cortada EMC.

4.3.3 Indicadores de consumo de insumos.

4.3.3.1 Consumo de combustível ponderado por distância média CDM.

4.3.3.2 Motores retificados no ano - MRA.

60

4.4 Indicadores analítico-descritivos.

4.4.1 Indicadores de idade.

4.4.1.1 Idade média dos equipamentos automotrizes - IEA ................ 63

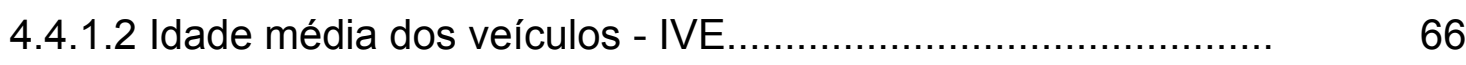

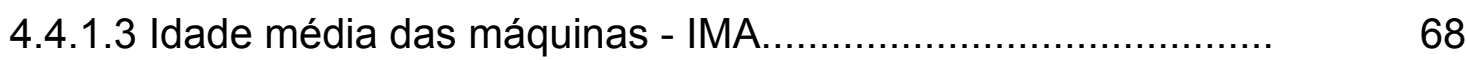

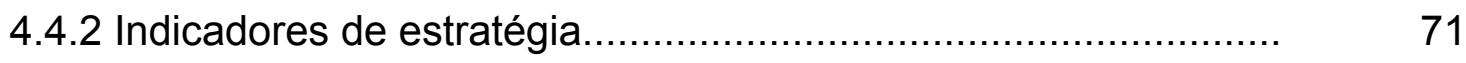

4.4.2.1 Terceirização dos equipamentos motorizados - TMT........... 72

4.4.2.2 Plantio mecanizado de cana - PMN..................................... 
4.4.2.3 Colheita mecanizada de cana - CMC.................................... 76

4.5 Resultados das empresas assíduas ................................... 78

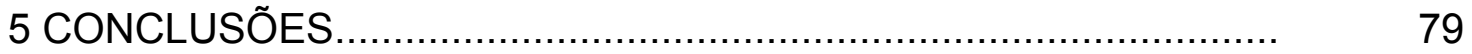

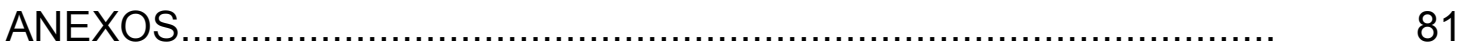

REFERÊNCIAS BIBLIOGRÁFICAS............................................... 94

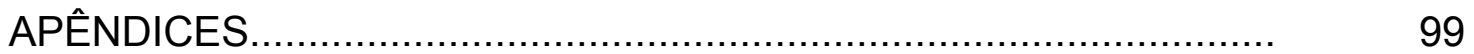




\section{LISTA DE FIGURAS}

Página

1 Proposta de sistematização de indicadores de desempenho para a gestão pela qualidade total, conforme Martins \& Costa Neto (1998)

2 Categorias de fontes supridoras de medidas sobre maquinaria agrícola e meios utilizados para aquisição de dados, segundo Donaldson (1970).

3 Inter-relação entre fatores que definem uma pesquisa, adaptado de Richardson et al. (1995).

4 Exemplo de apresentação de resultados da produtividade de caminhões canavieiros (PMC) em Nunes Júnior et al. (1998).............

5 Combinação "rodotrem" canavieiro para transporte de cana

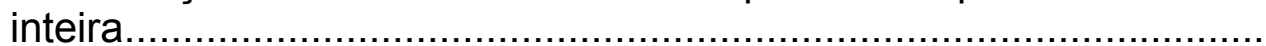

6 Combinação "treminhão" para transporte de cana picada................. 


\section{LISTA DE TABELAS}

Página

1 Participação de empresas agroindustriais canavieiras respondendo aos questionários da pesquisa deste estudo.......................................

2 Produtividade média dos caminhões canavieiros (t.dia.caminhão $o^{-1} \cdot \mathrm{km}^{-1}$ ) ao longo de três safras referente a todas as agroindústrias canavieiras amostradas

3 Estimativas populacionais com intervalo de confiança de $95 \%$ para produtividade média dos caminhões canavieiros (t.dia.caminhão ${ }^{-1} \cdot \mathrm{km}^{-1}$ ) ao longo de três safras

4 Produtividade média dos caminhões canavieiros (t.dia.caminhão ${ }^{1} \cdot \mathrm{km}^{-1}$ ) referente, somente, às agroindústrias canavieiras amostradas e que participaram igualmente das três safras pesquisadas. que participaram igualmente das três safras

5 Produtividade média dos caminhões canavieiros (t.dia.caminhão-1 $\mathrm{km}^{-1}$ ) referente, somente, às agroindústrias canavieiras amostradas e que não participaram igualmente das três safras pesquisadas

6 Diferenças com intervalo de confiança de $95 \%$ entre as médias da produtividade média dos caminhões canavieiros (t.dia.caminhão ${ }^{-1} \cdot \mathrm{km}^{-1}$ ) das amostras referente somente às agroindústrias canavieiras que participaram igualmente das três safras pesquisadas e das amostras das demais agroindústrias canavieiras. 
7 Massa de cana carregada por carregadora por dia efetivo de safra $\left(\right.$ t.dia.carregadora ${ }^{-1}$ ) ao longo de três safras referente a todas as agroindústrias canavieiras amostradas.

8 Estimativas populacionais com intervalo de confiança de 95\% para cana carregada por carregadora por dia efetivo de safra (t.dia.carregadora ${ }^{-1}$ ) ao longo de três safras.

9 Massa de cana carregada por carregadora por dia efetivo de safra $\left(\right.$ t.dia.carregadora $\left.{ }^{-1}\right)$ referente às agroindústrias canavieiras amostradas que participaram igualmente das três safras pesquisadas.

10 Massa de cana carregada por carregadora por dia efetivo de safra $\left(\mathrm{t}\right.$.dia.carregadora $\left.{ }^{-1}\right)$ referente às demais agroindústrias canavieiras que não participaram igualmente das três safras pesquisadas.

11 Diferenças com intervalo de confiança de $95 \%$ entre as médias da cana carregada por carregadora por dia efetivo de safra (t.dia.carregadora ${ }^{-1}$ ) das amostras referente somente às dezesseis agroindústrias canavieiras que participaram igualmente das três safras pesquisadas e das demais agroindústrias participantes.

12 Massa de cana colhida por colhedora de cana por dia efetivo de safra (t.dia.colhedora ${ }^{-1}$ ) ao longo de três safras referente a todas as agroindústrias canavieiras amostradas.

13 Estimativas populacionais com intervalo de confiança de 95\% para cana colhida por colhedora de cana por dia efetivo de safra (t.dia.colhedora ${ }^{-1}$ ) ao longo de três safras.

14 Massa de cana colhida por colhedora de cana por dia efetivo de safra (t.dia.colhedora ${ }^{-1}$ ) referente somente às dezesseis agroindústrias canavieiras amostradas que participaram igualmente das três safras pesquisadas.

15 Massa de cana colhida por colhedora de cana por dia efetivo de safra (t.dia.colhedora ${ }^{-1}$ ) referente às demais agroindústrias canavieiras amostradas que não participaram igualmente das três safras pesquisadas. 
16 Diferenças com intervalo de confiança de $95 \%$ entre as médias da cana colhida por colhedora de cana por dia efetivo de safra $\left(\right.$ t.dia.colhedora $\left.{ }^{-1}\right)$ das amostras referente somente às dezesseis agroindústrias canavieiras que participaram igualmente das três safras pesquisadas e das demais agroindústrias que não participaram igualmente das três safras.

17 Massa de cana colhida por cortadora de cana por dia efetivo de safra (t.dia.colhedora ${ }^{-1}$ ) ao longo de três safras referente a todas as agroindústrias canavieiras amostradas

18 Estimativas populacionais com intervalo de confiança de 95\% para cana colhida por cortadora de cana por dia efetivo de safra (t.dia.colhedora ${ }^{-1}$ ) ao longo de três safras.

19 Número de equipamentos motorizados por $10^{3}$ ha de cana cortada (equipamento. $10^{-3}$ ha) ao longo de três safras referente a todas as agroindústrias canavieiras amostradas

20 Estimativas populacionais com intervalo de confiança de $95 \%$ para equipamentos motorizados por $10^{3}$ ha de cana cortada (equipamento. $10^{-3} \mathrm{ha}$ ) ao longo de três safras

21 Número de equipamentos motorizados por $10^{3}$ ha de cana cortada (equipamento. $10^{-3}$ ha) referente somente às dezesseis agroindústrias canavieiras amostradas que participaram igualmente das três safras pesquisadas.

22 Número de equipamentos motorizados por $10^{3}$ ha de cana cortada (equipamento. $10^{-3} \mathrm{ha}$ ) referente às demais agroindústrias canavieiras amostradas que não participaram igualmente das três safras pesquisadas.

23 Diferenças com intervalo de confiança de $95 \%$ entre as médias de equipamentos motorizados por $10^{3}$ ha de cana cortada (equipamento. $10^{-3}$ ha) das amostras referente somente às dezesseis agroindústrias canavieiras que participaram igualmente das três safras pesquisadas e das demais agroindústrias que não participaram igualmente das três safras.

24 Consumo de combustível ponderado por distância média (I.km.ha $\left.{ }^{-1}\right)$ ao longo de três safras referente a todas as agroindústrias canavieiras amostradas 
25 Estimativas populacionais com intervalo de confiança de $95 \%$ para consumo de combustível ponderado por distância média (I.km.ha $\left.{ }^{-1}\right)$ ao longo de três safras.

26 Consumo de combustível ponderado por distância média (l.km.ha-1) referente somente às dezesseis agroindústrias canavieiras amostradas que participaram igualmente das três safras pesquisadas.

27 Consumo de combustível ponderado por distância média (l.km.ha $\left.{ }^{-1}\right)$ referente às demais agroindústrias canavieiras amostradas que não participaram igualmente das três safras pesquisadas.

28 Diferenças com intervalo de confiança de 95\% entre as médias de consumo de combustível ponderado por distância média (I.km.ha $\left.{ }^{-1}\right)$ das amostras referente somente às dezesseis agroindústrias canavieiras que participaram igualmente das três safras pesquisadas e das demais agroindústrias que não participaram igualmente das três safras.

29 Motores retificados no ano (\%) ao longo de três safras referente a todas as agroindústrias canavieiras amostradas.

30 Estimativas populacionais com intervalo de confiança de $95 \%$ para motores retificados no ano (\%) ao longo de três safras.

31 Motores retificados no ano (\%) ao longo de três safras referente somente às agroindústrias canavieiras amostradas que participaram igualmente das três safras pesquisadas.

32 Motores retificados no ano (\%) ao longo de três safras referente às demais agroindústrias canavieiras amostradas que não participaram igualmente das três safras pesquisadas.

33 Diferenças com intervalo de confiança de $95 \%$ entre as médias de motores retificados no ano (\%) das amostras referente somente às dezesseis agroindústrias canavieiras que participaram igualmente das três safras pesquisadas e das demais agroindústrias que não participaram igualmente das três safras.

34 Idade média dos equipamentos automotrizes (anos) nas empresas amostradas nas três safras estudadas (1997/1998, 1998/1999 e 1999/2000). 
35 Estimativas populacionais com intervalo de confiança de 95\% para idade média dos equipamentos automotrizes (anos) ao longo de três safras.

36 Diferenças com intervalo de confiança de 95\% entre as médias de idade média dos equipamentos automotrizes (anos) das amostragens das três safras, safra a safra

37 Idade média dos veículos (anos) nas empresas amostradas nas três safras estudadas (1997/1998, 1998/1999 e 1999/2000).

38 Estimativas populacionais com intervalo de confiança de 95\% para idade média dos veículos (anos) ao longo de três safras.

39 Diferenças com intervalo de confiança de 95\% entre as médias de idade média dos veículos (anos) das amostragens das três safras, safra a safra.

40 Idade média das máquinas (anos) nas empresas amostradas nas três safras estudadas (1997/1998, 1998/1999 e 1999/2000).

41 Estimativas populacionais com intervalo de confiança de 95\% para idade média das máquinas (anos) ao longo de três safras.

42 Diferenças com intervalo de confiança de 95\% entre as médias de idade média das máquinas (anos) das amostragens das três safras, safra a safra.

43 Terceirização (\%) dos equipamentos motorizados nas empresas amostradas entre 1997/1998 e 1999/2000

44 Estimativas populacionais com intervalo de confiança de 95\% para a terceirização (\%) dos equipamentos motorizados ao longo de três safras.

45 Diferenças com intervalo de confiança de 95\% entre as médias de terceirização (\%) dos equipamentos motorizados das amostragens das três safras, safra a safra.

46 Plantio mecanizado de cana (\%) nas empresas amostradas entre $1997 / 1998$ e $1999 / 2000$

47 Estimativas populacionais com intervalo de confiança de 95\% para o plantio mecanizado de cana (\%) ao longo de três safras 
48 Diferenças com intervalo de confiança de $95 \%$ entre as médias de plantio mecanizado de cana (\%) das amostragens das três safras,

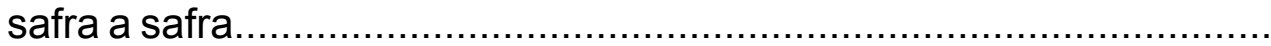

49 Colheita mecanizada de cana (\%) nas unidades produtoras amostradas entre 1997/1998 e 1999/2000.

50 Estimativas populacionais com intervalo de confiança de $95 \%$ para colheita mecanizada de cana (\%) ao longo de três safras.....

51 Diferenças com intervalo de confiança de 95\% entre as médias de colheita mecanizada de cana (\%) das amostragens das três safras, safra a safra. 


\section{LISTA DE SIGLAS, ABREVIATURAS E SÍMBOLOS}

$$
\begin{aligned}
& \mathrm{t}=\text { tonelada } \\
& \mathrm{km}=\text { quilômetro } \\
& \mathrm{ha}=\text { hectare } \\
& \mathrm{I}=\text { litro } \\
& \% \text { = porcento }
\end{aligned}
$$

t.km.caminhão ${ }^{-1} \cdot \mathrm{dia}^{-1}=$ tonelada por caminhão por quilômetro por dia

t.dia.colhedora ${ }^{-1}=$ tonelada por colhedora por dia

t. dia.carregadora ${ }^{-1}=$ tonelada por carregadora por dia

equipamento. $10^{-3}$ ha $=$ equipamento por 1000 hectares

I.km.ha ${ }^{-1}=$ litro por hectare por $\mathrm{km}$

$\mathrm{ACM}=$ área de colheita mecanizada

APM = área de plantio mecanizado

$\mathrm{CCA}=$ número de caminhões canavieiros próprios e alugados empregados na safra

$C C D=$ massa de cana carregada por carregadora por dia efetivo de safra $\mathrm{CCl}=$ massa de cana colhida por cortadoras próprias de cana na safra 
$\mathrm{CCP}=$ massa de cana carregada por carregadoras própria na safra

CDM = consumo de combustível ponderado por distância média

CID = massa de cana colhida por cortadora de cana por dia efetivo de safra

$\mathrm{CLI}$ = número de cortadoras próprias de cana

$\mathrm{CLP}=$ número de colhedoras próprias de cana

$\mathrm{CMC}=$ colheita mecanizada de cana

$\mathrm{CPD}=$ massa de cana colhida por colhedora de cana por dia efetivo de safra

$\mathrm{CPI}=$ massa de cana colhida por colhedoras próprias na safra

$\mathrm{CR}=$ número de carregadoras de cana próprias

$D_{1-2}=$ diferença entre médias populacionais 1 e 2

$\mathrm{DEF}=$ número de dias efetivos da safra

DMF = distância média das glebas à indústria

$E A I=$ número de equipamentos automotrizes da idade $\mathrm{i}$

$\mathrm{EM}=$ número de equipamentos motorizados próprios da frota

$\mathrm{EMC}=$ equipamentos motorizados por $10^{3}$ hectares de cana cortada

$\mathrm{EMI}=$ número de máquinas da idade $\mathrm{i}$

$\mathrm{EMT}$ = número de equipamentos motorizados próprios e alugados na safra

$\mathrm{HCC}=$ área total de colheita

$\mathrm{HPL}=$ área de cana plantada

IEA = idade média dos equipamentos automotrizes

IMA = idade média das máquinas

IVE = idade média dos veículos

IVT = índice de verticalização do transporte de cana 
$\mathrm{MR}=$ número de motores retificados da frota no ano

$\mathrm{MRA}=$ motores retificados no ano

$\mathrm{n}=$ número de amostras

$\mathrm{n}_{1}=$ número de amostras da $1^{\mathrm{a}}$ população

$\mathrm{n}_{2}=$ número de amostras da $2^{\mathrm{a}}$ população

$\mathrm{N}$ = número total da população, quando finita

OD = volume de combustível de motores de ciclo Diesel consumido no ano pela frota

$\mathrm{PMC}=$ produtividade média dos caminhões canavieiros

$\mathrm{PMN}=$ plantio mecanizado de cana

PTP = massa total de cana transportada na safra por veículos próprios

PTT = massa total de cana transportada na safra

$\mathrm{QEA}=$ número total de equipamentos automotrizes da frota

QMA = número total de máquinas da frota

$\mathrm{QTE}=$ número total de equipamentos motorizados presentes na frota

QTT = número de equipamentos motorizados terceirizados na frota

QV = número total de veículos

$s=$ desvio padrão da amostra

$\mathrm{s}_{1}=$ desvio padrão da amostra da $1^{\text {a }}$ população

$\mathrm{s}_{2}=$ desvio padrão da amostra da $2^{\mathrm{a}}$ população

$\mathrm{s}_{\mathrm{x}}=$ erro padrão da amostra

$\mathrm{t}(\mathrm{n} 1+\mathrm{n} 2-2)=$ número de unidades de desvios padrões a partir da média em distribuição $t$ de Student 
TMT = terceirização dos equipamentos motorizados

$\mathrm{VI}$ = número de veículos da idade $\mathrm{i}$

$\mathrm{x}=$ média da amostra

$\mathrm{x}_{1}=$ média da amostra da $1^{\mathrm{a}}$ população

$\mathrm{x}_{2}=$ média da amostra da $2^{\mathrm{a}}$ população

$Z$ = número de unidades de desvios padrões a partir da média 


\title{
INDICADORES DE DESEMPENHO DE FROTA DE EMPRESAS AGROINDUSTRIAIS CANAVIEIRAS BRASILEIRAS
}

\author{
Autor: RICARDO SOARES DE ARRUDA PINTO \\ Orientador: Prof. Dr. TOMAZ CAETANO CANNAVAN RIPOLI
}

\section{RESUMO}

Este trabalho tem como objetivo avaliar um conjunto proposto de indicadores analítico-descritivos e de avaliação de desempenho para frotas de agroindústrias canavieiras brasileiras, já que o Brasil, conforme Lucchesi (1995), é o maior produtor mundial de cana e esta cultura, segundo Paixão (1994), dá trabalho a $3 \%$ do total de pessoas empregadas no meio rural do país. Para a coleta de dados dos testes, um questionário foi aplicado para as 323 usinas de açúcar e álcool brasileiras existentes entre 1998 (safra 1997/1998) e 2000 (safra 1999/2000). Na safra 1997/1998, 67 empresas participaram, enquanto foram 73 na safra 1998/1999 e novamente 73 unidades produtoras na safra 1999/2000. Os resultados obtidos mostraram a efetividade dos indicadores sugeridos como ferramenta de gerenciamento das frotas canavieiras, além de mostrarem a 
tendência das frotas das agroindústrias canavieiras de envelhecimento entre 1997/1998 e 1999/2000 e também de crescimento da sua terceirização. Os resultados também apontam para uma tendência dentre as empresas de crescimento da área com colheita mecanizada e do plantio mecanizado. 


\title{
FLEET PERFORMANCE INDICATORS OF BRAZILIAN SUGARCANE AGRO-INDUSTRIAL ENTERPRISES
}

\author{
Author: RICARDO SOARES DE ARRUDA PINTO \\ Adviser: Prof. Dr. TOMAZ CAETANO CANNAVAN RIPOLI
}

\section{SUMMARY}

The present work is aimed at evaluating a group of proposed analyticaldescriptive and performance indicators in Brazilian agro-industry sugarcane fleets. Brazil is the world's greatest sugarcane producer (Lucchesi, 1995) and this activity employees $3 \%$ of the rural labor in the country (Paixão, 1994). The data for testing the proposed group of indicators were collected by means questionnaires filled in by sugarcane agro-industries between 1998 (1997/1998 crop) and 2000 (1999/2000 crop). The number of companies involved in the research were 67, 73 and 73 during the $1997 / 1998,1998 / 1999$ and 1999/2000 crops, respectively. The results showed that the evaluated indicators can be used as an effective toll for sugarcane fleets management, besides evidencing an aging tendency of the fleets between 1997/1998 and 1999/2000, as well as an increase in outsourcing. The 
results also showed a trend toward mechanized planting and mechanized harvest in sugarcane enterprises. 


\section{INTRODUÇÃO}

\subsection{0 problema e sua importância}

A lavoura canavieira no Brasil expandiu-se significativamente, atingindo mais de 300 milhões de toneladas na safra 1997/1998. O Brasil é o maior produtor de cana-de-açúcar do mundo. Com a cana-de-açúcar há a produção de açúcar, álcoois combustíveis e industriais, aguardente, cera, além de ser consumida in natura. O bagaço da cana-de-açúcar é fonte para a produção de energia e papel. A ponta da cana pode também ser utilizada como alimentação animal e para extração de palmito para alimentação humana. Desta forma, a cana-de-açúcar é uma das mais importantes culturas brasileiras (Lucchesi, 1995).

Paixão (1994) cita que, segundo os empresários do setor, a atividade sucroalcooleira oferece emprego a $3 \%$ do total de pessoas empregadas nas atividades agrícolas em todo o Brasil, somando 800 mil cortadores de cana na safra, 200 mil operários nas agroindústrias e mais 700 mil empregos indiretos correlatos. 
Numa agroindústria canavieira brasileira, grande parte das operações agrícolas necessárias à produção, colheita e transporte da cana-de-açúcar é mecanizada, tornando a frota uma área-chave do negócio. Veiga Filho (1998) afirma que, no sub-setor sucroalcooleiro paulista, o preparo de solo e a fase dos tratos culturais já são totalmente mecanizados, enquanto que o plantio e a colheita ainda utilizam sistemas parcialmente mecanizados.

Banchi \& Machado (1988) afirmam que a frota canavieira representa, aproximadamente, $20 \%$ do custo global de produção de uma empresa sucroalcooleira. Desta forma, é intrínseca a relação entre o desempenho da frota canavieira e o desempenho da empresa como um todo.

A tarefa de melhor administrar recursos, visando a otimização de seu emprego, é a base do desenvolvimento da ciência econômica, conforme cita Filgueiras (1997). Além disso, Sink (1991) salienta que as mudanças tecnológicas, ambientais e de competição demandam que se mude o que se mede, como se mede e como se usa a medida, forçando o reexame dos paradigmas relativos à medição. É, justamente, neste âmbito que o presente trabalho se insere, através da proposição de um conjunto de indicadores de desempenho e analítico-descritivos de frotas que possa ser adotado por empresas agroindustriais canavieiras para medir ítens do gerenciamento de sua frota e poder otimizar-Ihe a operação.

\subsection{Objetivo}


O presente estudo teve como principal objetivo a análise da aplicação de indicadores propostos de desempenho e analítico-descritivos para frotas canavieiras que possibilitem planejá-las, diagnosticar-lhes tanto aspectos positivos como ineficácias e ineficiências, monitorar-lhes a produtividade e controlar suas irregularidades. 


\section{REVISÃO DE LITERATURA}

\subsection{Gestão por indicadores}

Castello Branco (1998) diz que, em termos de planejamento, os indicadores possibilitam a fixação de metas físicas e monetárias, globais e setoriais, que permeiam toda a organização. No caso do acompanhamento, os indicadores fornecem elementos fundamentais para análise crítica e retroanálise do desempenho, comparativamente às metas planejadas. E, com relação ao controle, os indicadores constituem valiosos ferramentais para o replanejamento de atividades e reprogramação de metas.

Takashina \& Flores (1997) falam que a internalização dos indicadores de qualidade e desempenho introduzem o processo de Gestão de Indicadores, cujas principais fases são:

a) preparação,

b) definição das metas e indicadores,

c) implantação de sistema de informação,

d) análise dos dados e resultados, 
e) uso dos dados e resultados,

f) ciclo de avaliação e melhoria.

Indicadores são essenciais ao planejamento e controle dos processos das organizações. No planejamento, possibilitam o estabelecimento de metas quantificadas e o seu desdobramento para a organização. Já no controle, através dos resultados, proporcionam a análise crítica do desempenho da organização, visando tomadas de decisão e replanejamento (Takashina \& Flores, 1997).

Fundação Nacional para o Prêmio Qualidade - FNPQ (1995) afirma que a comparação, via indicadores, com referenciais de excelência pode dar uma grande contribuição para a identificação de possibilidades mais amplas de melhorias numa empresa. Assim, o conceito de desempenho tem como pressuposto a comparação dos resultados obtidos, interna (com metas e padrões) e externamente, com referenciais pertinentes. Uma organização só poderá precisar sua posição competitiva caso possua informações de resultados e de melhores práticas de outras organizações que lhe sirvam como impulsionadoras na busca da excelência. A publicação também mostra que o processo de comparação com as melhores práticas pode incluir a comparação de estratégias, procedimentos, operações, sistemas, processos, produtos, serviços e seus respectivos resultados.

Tavares (2000) explica que "benchmark" é o indicador de um líder reconhecido, usado para comparação, enquanto "benchmarking" é a atividade de comparar um processo com líderes reconhecidos, inclusive de outros ramos, para identificar as oportunidades de melhoria. 
O autor ainda afirma que "benchmarking" pode também ser definido como a busca das melhores práticas na indústria, as quais conduzem ao desempenho superior. Desta forma, o "benchmarking" contribui para a organização fixar uma meta de melhoria, superar as expectativas dos clientes, reprojetar o processo e recuperar o atraso tecnológico. O resultado obtido deve ser comparado com a meta e com resultados de períodos passados, além de referenciais de comparação, tais como a média do setor, o melhor concorrente, um concorrente potencial e/ou o referencial de excelência.

Martins \& Costa Neto (1998) destacam que os indicadores de desempenho são um meio para auxiliar a gestão pela qualidade total, mas não são um fim em si mesmos. Eles são úteis para que o sistema de gestão possa controlar e identificar necessidades e melhorar o desempenho, fatores estes que estão relacionados à satisfação dos clientes, empregados, acionistas, sociedade e fornecedores da empresa. Afirmam, ainda, que a partir do momento que se estabelecem indicadores de desempenho corporativos, o passo seguinte é desdobrá-los para os macro e microprocessos da organização, tendo-se coerência entre os indicadores utilizados em todos os níveis de gerência da empresa, conforme a Figura 1. 


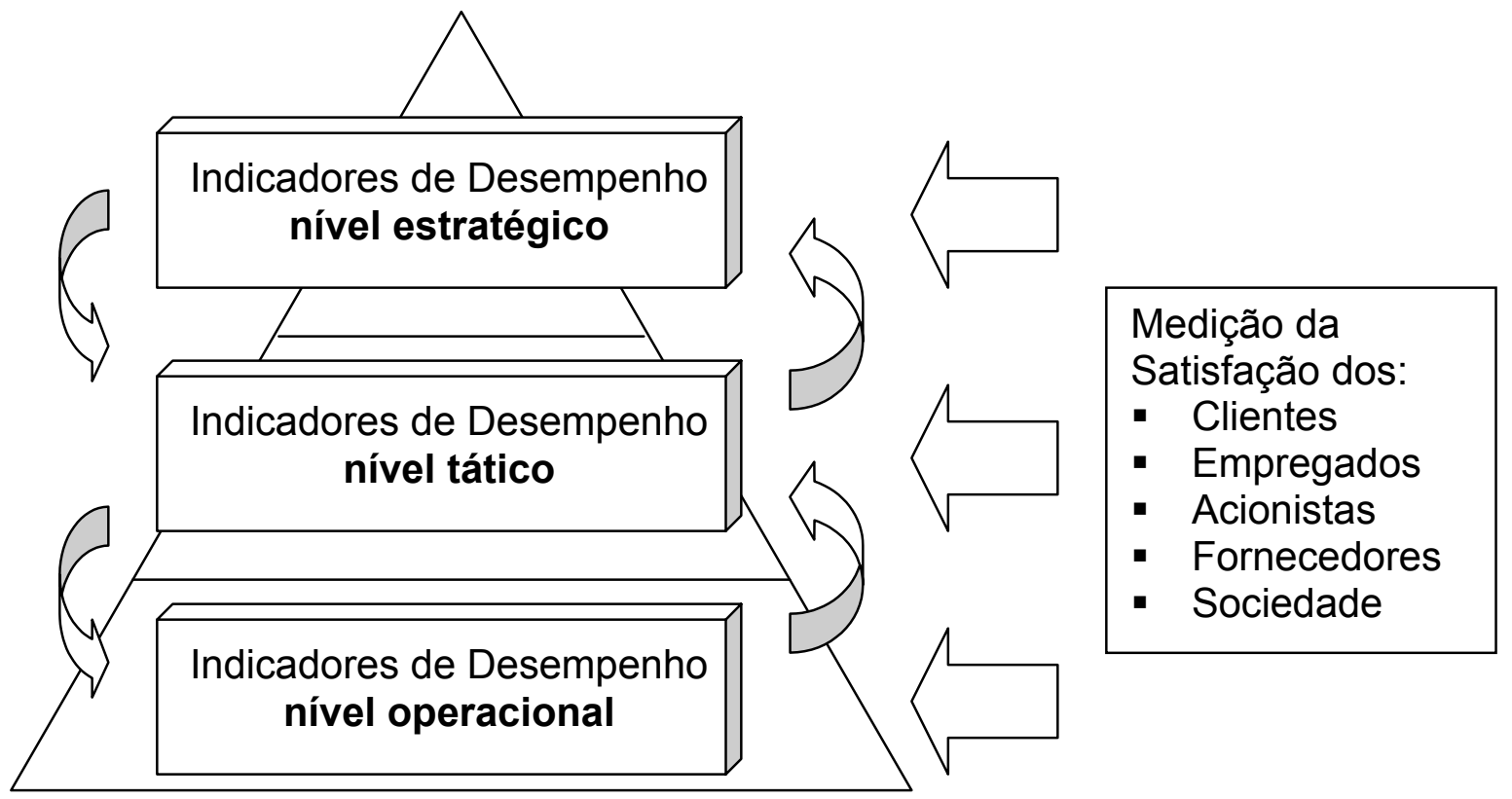

Figura 1 - Proposta de sistematização de indicadores de desempenho para a gestão pela qualidade total, conforme Martins \& Costa Neto (1998).

Francischini (1998) alerta para a importância de índices quantitativos no processo administrativo, pois lembra que o suporte às decisões tomadas deve, na medida do possível, evitar análises qualitativas. Análises qualitativas são geralmente precedidas por um "eu acho que..." como, por exemplo: eu acho que a produção melhorou; eu acho que o estoque está baixo; eu acho que os funcionários estão mais satisfeitos; eu acho que a manutenção está ruim; eu acho que tem um jacaré no telhado... Achar, qualquer um pode achar o que quiser! $\mathrm{E}$ com este artifício, uma reunião de diretoria pode transformar-se em uma reunião de comadres, onde todo mundo acha e ninguém demonstra efetivamente nada.

\subsection{Emprego de indicadores}


Silva (1999) cita que existem vários trabalhos que analisam os indicadores de eficiência e eficácia em sistemas de transportes, principalmente no transporte público urbano. Para o segmento de transporte de cargas, ele selecionou os seguintes seis grupos de indicadores para avaliação de empresas transportadoras: intensidade de utilização, racionalidade do tempo operacional, realização do programado, desempenho da manutenção, desempenho econômico e produtividade nos terminais.

O grupo sobre intensidade de utilização possui os seguintes indicadores:

a) índice de aproveitamento do veículo $(\%)=\left(\right.$ TCT . 100) $\cdot \mathrm{CC}^{-1}$

onde:

TCT $=$ carga transportada pelo veículo $(\mathrm{t})$,

$\mathrm{CC}=$ capacidade de carga do veículo $(\mathrm{t})$.

b) tonelagem média transportada por $\mathrm{km}\left(\mathrm{t} . \mathrm{km}^{-1}\right)=\mathrm{TTM} . \mathrm{Tkm}^{-1}$ onde:

$\mathrm{TTM}=$ carga total de mercadorias transportadas $(\mathrm{t})$,

$\mathrm{Tkm}=$ quilometragem total percorrida $(\mathrm{km})$.

O segundo grupo, que trata da racionalidade do tempo operacional, é composto pelos indicadores:

a) aproveitamento do tempo de operação $\left(\mathrm{km} \cdot \mathrm{h}^{-1}\right)=(\mathrm{N} \cdot \mathrm{Tkm}) \cdot \mathrm{HO}^{-1}$ onde:

$\mathrm{N}$ = número de veículos avaliados,

$\mathrm{Tkm}=$ quilometragem total percorrida $(\mathrm{km})$, 
$\mathrm{HO}=$ tempo útil de operação $(\mathrm{h})$.

Com relação ao grupo de realização do programado, os indicadores são:

a) índice de cumprimento da oferta $(\%)=(\mathrm{N} . \mathrm{Tkm} \cdot 100) \cdot(\mathrm{N} . \mathrm{Pkm})^{-1}$

onde:

$\mathrm{N}$ = número de veículos avaliados,

$\mathrm{Tkm}$ = quilometragem total percorrida $(\mathrm{km})$,

$\mathrm{Pkm}=$ quilometragem programada a percorrer $(\mathrm{km})$.

b) índice de cumprimento de viagens $(\%)=(\mathrm{VR} .100) \cdot V \mathrm{P}^{-1}$

onde:

VR = número de viagens realizadas,

$\mathrm{VP}=$ número de viagens programadas.

O grupo de indicadores de desempenho da manutenção é integrado por:

a) disponibilidade da frota - D

$D(\%)=[(T-T I) \cdot 100] \cdot T^{-1}$

Com:

$\mathrm{TI}=\mathrm{TMP}+\mathrm{TMC}+\mathrm{TMO}$

$\mathrm{T}=\mathrm{NV} . \mathrm{ND} . \mathrm{HO}$

Onde:

TMP = tempo consumido em manutenção preventiva no período $(h)$,

TMC = tempo consumido em manutenção corretiva no período $(\mathrm{h})$,

$\mathrm{TMO}=$ tempo consumido em outras atividades de manutenção $(\mathrm{h})$,

$\mathrm{NV}=$ quantidade de veículos na frota

ND = número de dias de operação (dia), 
$\mathrm{HD}=$ tempo operacional diário $\left(\mathrm{h} \cdot \mathrm{dia}{ }^{-1}\right)$.

b) índice de indisponibilidade da frota $(\%)=\left(T V I\right.$. 100) $\cdot \mathrm{TF}^{-1}$ onde:

$\mathrm{TVI}$ = número de veículos indisponíveis, TF = número total de veículos da frota.

c) quilometragem média entre falhas $\left(\mathrm{km} \cdot \mathrm{falha}^{-1}\right)=\mathrm{KP} \cdot \mathrm{QF}^{-1}$ onde:

$\mathrm{KP}=$ quilometragem percorrida pela frota no período $(\mathrm{km})$, $\mathrm{QF}=$ quantidade total de falhas ocorridas no período.

d) tempo médio parado em conserto por veículo (h).

e) ocorrência mensal de acidentes com veículos da empresa.

O grupo de desempenho econômico possui como indicadores:

a) índice de consumo de combustível $\left(I . \mathrm{km}^{-1}\right)=\left(\mathrm{TL}\right.$. 100). $\mathrm{TKM}^{-1}$ onde:

$\mathrm{TL}=$ volume total de combustível consumido (I), $\mathrm{Tkm}$ = quilometragem total percorrida $(\mathrm{km})$.

b) quilometragem média percorrida por litro transportando carga $\left(\mathrm{km} \cdot \mathrm{l}^{-1}\right)$.

c) quilometragem média percorrida por litro sem carga transportada $\left(\mathrm{km} . \mathrm{I}^{-1}\right)$.

d) quilometragem média percorrida com o mesmo "jogo" de pneus ( $\mathrm{km})$.

e) índice de custos $x$ receita $(\%)=(C T \cdot 100) \cdot R^{-1}$ onde:

$C T$ = custo total da empresa $(R \$)$,

$\mathrm{RT}=$ receita total da empresa $(\mathrm{R} \$)$. 
E, finalmente, o grupo de produtividade nos terminais é formado pelos indicadores:

a) quantidade de carga transferida $\left(\mathrm{t} \cdot \mathrm{dia}^{-1}\right)$.

b) tempo médio parado esperando carregamento e descarregamento (h).

c) tempo médio parado nas operações de carga / descarga (h).

d) distância de transporte entre terminal e destino $(\mathrm{km})$.

No caso de transporte de passageiros, Valente et al. (1997) dizem ser importante que os técnicos da área façam bom uso dos métodos de controle operacional e disponham de indicadores de desempenho atualizados, para melhor avaliar a situação real de cada sistema e atuar com eficiência. Dentre os parâmetros de desempenho operacional que os autores citam, estão: total diário de passageiros transportados, subdividido em passageiros gratuitos (idosos e outros), com desconto (estudantes) e passageiros sem desconto; total diário de quilômetros percorridos, subdividido em quilometragem útil e ociosa, sendo que a quilometragem útil é a soma das quilometragens de todas as viagens realizadas do ponto inicial ao final, ida e volta; total diário de viagens programadas e realizadas; total diário de ônibus utilizados, especificando a frota reserva e a média de veículos em manutenção; e cadastro dos pontos de parada e terminais.

Os autores ainda definem os índices de controle operacional e os de desempenho econômico. O primeiro grupo é composto por: índice de passageiros transportados por quilômetro (IPK), índice de passageiros transportados por viagem, índice de quilômetros percorridos por veículo ao dia, percurso médio mensal, índice de regularidade do sistema - que retrata a porcentagem das 
viagens programadas que foi realizada -, índice de renovação - que reflete o embarque-desembarque nas linhas -, idade média da frota, índice de conforto que espelha a porcentagem de passageiros transportados sentados espaçamento médio entre pontos de parada, número de paradas por linha, tempo no terminal e tempo total de viagem.

O segundo grupo, sobre desempenho econômico, é composto por: tarifa média paga, índice de tarifa social, índice de consumo de combustível e índice de rentabilidade média da empresa.

Castello Branco (1998), em seu compêndio sobre indicadores da qualidade e desempenho de ferrovias, subdivide os indicadores em oito grupos: relação com o cliente, participação no mercado, desempenho da operação, desempenho da manutenção, desempenho financeiro, desempenho de fornecedores e desempenho dos recursos humanos. Especificamente no grupo de indicadores de desempenho da operação, onde o autor lista 33 índices que espelham, sinteticamente: o aproveitamento e utilização da frota, seu consumo de energia, o grau de cumprimento das viagens programadas, a disponibilidade e a indisponibilidade da frota, a lotação dos trens, classificação dos passageiros, a produtividade das locomotivas, trens e vagões, a pontualidade dos trens, a operacionalidade dos vagões, emprego de trens extras, a transferência de passageiros, velocidade de operação, e volume de tráfego dos trens.

\subsection{Mensuração de indicadores}


A frota canavieira, não obstante seja agrícola ou rodoviária, possui um número reduzido de estudos, principalmente no que se refere às informações sobre seu desempenho. Além disso, a mecanização da lavoura canavieira está crescendo significativamente nos últimos anos, principalmente nas operações de colheita e plantio, onde sua participação era, até então, marginal. Desta forma, torna-se imprescindível que sejam definidos indicadores representativos de seu desempenho. Mas, para que sejam obtidos os indicadores, mensurações devem ser feitas.

Mialhe (1996) cita que "medida é o resultado da comparação de uma grandeza de qualquer ordem com outra fixa, da mesma natureza, tomada como padrão de unidade. Ela constitui a mais precisa forma de informação a respeito dos vários fatores, de ordem física, temporal ou econômica, que intervêm numa tomada de decisão sobre mecanização agrícola". Donaldson ${ }^{1}$, citado por Mialhe (1996), classificou as diferentes fontes supridoras de dados requeridos para medidas em três categorias: ensaios, levantamentos e registros. O autor explica que os ensaios refletem uma mensuração mais altamente especializada e específica (em pequenas ou em única amostra), enquanto que os registros atuam com uma coleta de dados mais geral (feitos sobre uma população ou um universo estatístico), ficando os levantamentos numa situação intermediária entre ambos. A Figura 2 ilustra a aquisição de dados de cada uma dessas fontes.

1 DONALDSON, G. F. Farm machinery testing: scope and purpose in the measurement and evaluation of farm machinery. Otawwa: Royal Commission on Farm Machinery, 1970. 91p. 


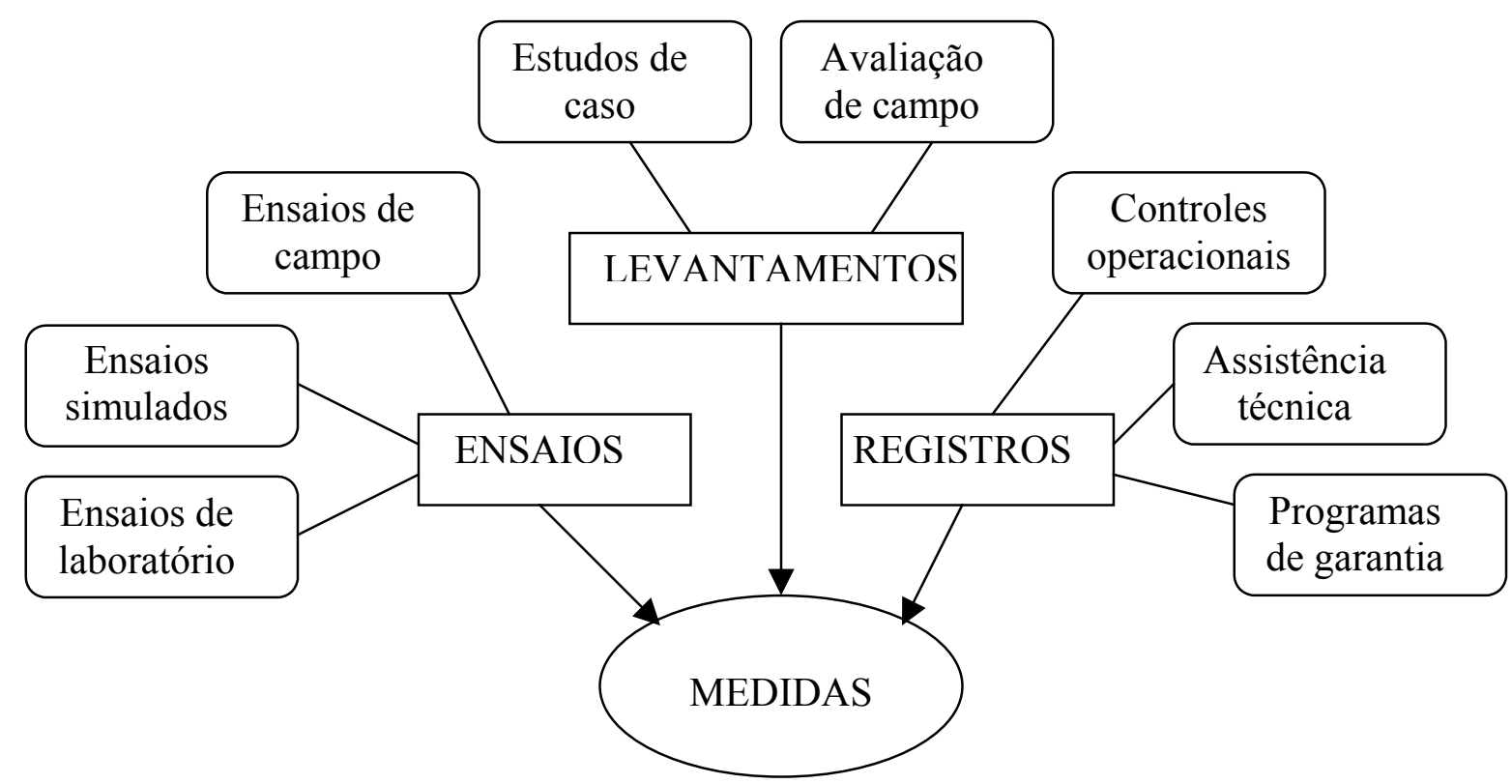

Figura 2 - Categorias de fontes supridoras de medidas sobre maquinaria agrícola e meios utilizados para aquisição de dados, segundo Donaldson ${ }^{2}$, citado por Mialhe (1996).

Sink \& Tuttle (1993) dizem que é difícil gerenciar eficazmente algo que não é medido corretamente, enquanto que Rummler \& Branche (1994) afirmam que a medição é o instrumento central do gerenciamento e aperfeiçoamento do desempenho. Por isso, sugerem, merece um tratamento especial.

Para medir o desempenho de uma frota canavieira, portanto, é necessário que se possua um conjunto bem definido de critérios de mensuração e de indicadores das práticas correntes.

\subsection{Métodos de pesquisa}

2 DONALDSON, G. F. Farm machinery testing: scope and purpose in the measurement and evaluation of farm machinery. Otawwa: Royal Commission on Farm Machinery, 1970. 91p. 
Conforme Richardson et al. (1995), é fundamental a escolha do método apropriado para a pesquisa de dados, aliando os objetivos buscados com os recursos disponíveis para tal. A Figura 3 ilustra esta inter-relação.

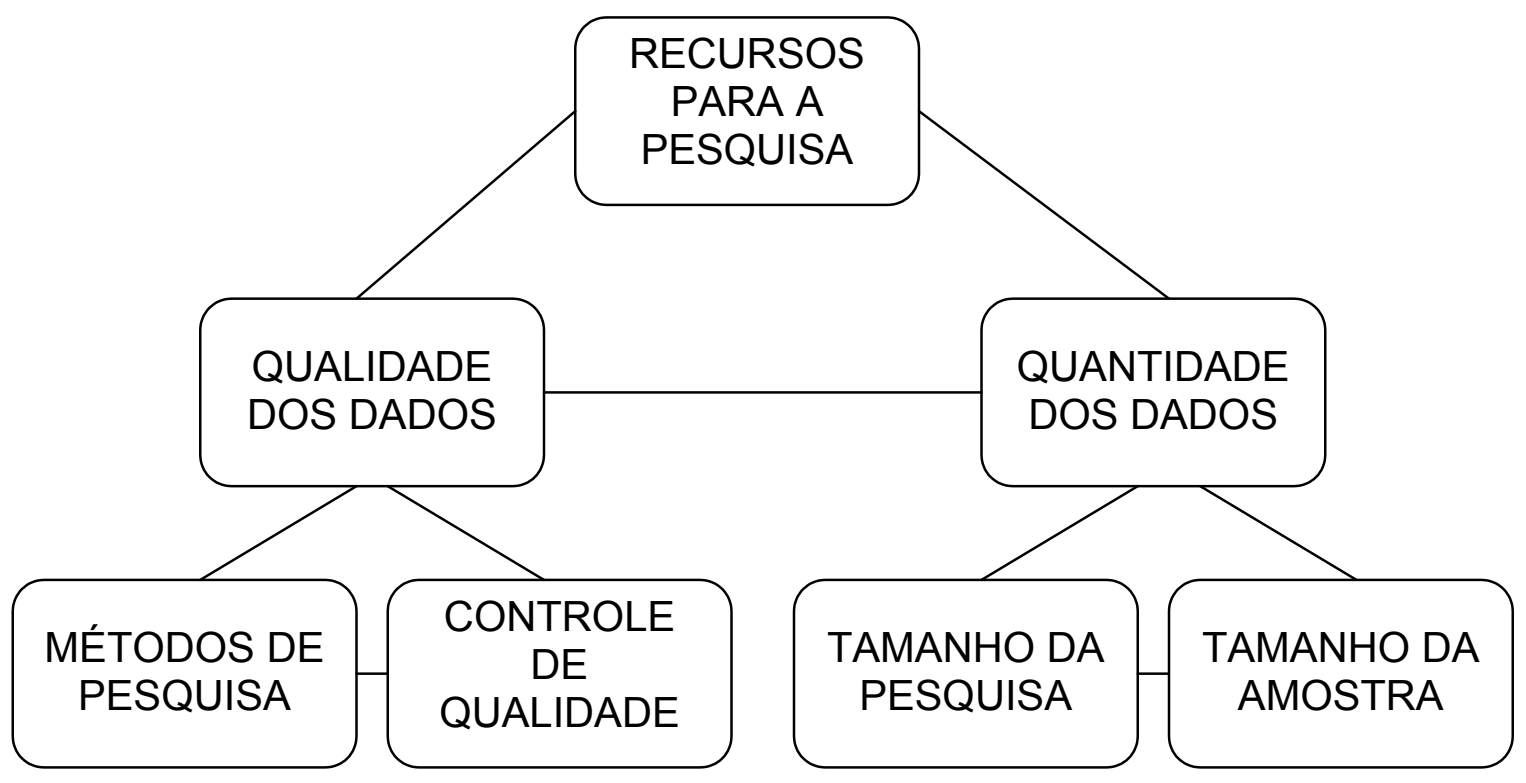

Figura 3 - Inter-relação entre fatores que definem uma pesquisa, adaptado de Richardson et al. (1995).

Ainda, segundo o mesmo autor, existem 8 tipos de diferentes técnicas de coleta de dados:

a) busca documental: quando o objetivo é uma simples busca de documentos publicados e não publicados e banco de dados para descobrir a informação desejada; 
b) pesquisa de observação: voltada à obtenção de dados por verificação in loco e normalmente usada para validar resultados obtidos de entrevistas individuais e/ou de pesquisa de autopreenchimento, são comuns em transportes, principalmente no tocante a tráfego;

c) pesquisa de abordagem: é conduzida fora da residência, enquanto o entrevistado utiliza um modo qualquer de transporte. Por não haver uma regra definida quanto à seleção dos entrevistados, esta forma impossibilita o conhecimento da população da qual a amostra é extraída;

d) pesquisa domiciliar de entrevista: é caracterizada pelo entrevistador, que faz as perguntas e anota as respostas. Pesquisas de abordagem e telefônicas podem ser consideradas dentro desta categoria;

e) pesquisa grupal: ideais para testes pré-piloto de questionários, quando ainda não se tem uma expectativa segura do que será encontrado;

f) pesquisa em profundidade: orientada para penetrar abaixo da superficialidade das pesquisas de formato perguntas e respostas, caracteriza-se por entrevistas longas e que são gravadas. Normalmente é feita com um grupo de pessoas, embora também possa ser realizada apenas com um indivíduo; 
g) pesquisa telefônica: de abordagem barata e com maior abrangência geográfica, tem como desvantagem o entrevistado possuir uma baixa tolerância a entrevistas longas;

h) pesquisa de auto-preenchimento: é uma das formas de pesquisa mais utilizadas em sistemas de transporte, caracterizada por três fases: leitura e entendimento da questão, mentalização da resposta e transcrição desta para o questionário. Costuma ser mais barata do que a pesquisa de entrevista individual, além do entrevistado possuir maior tempo para responder às questões, o que facilita uma consulta mais detalhada. Como desvantagem para o método, temse o baixo índice de respostas dos questionários enviados e a incerteza de quem responderá as enquetes.

Luck \& Rubin (1987) apontam que o questionário é uma forma organizada de se obter e registrar informações específicas e relevantes com exatidão e abrangência necessárias. Já Green et al. (1988) mostram que a comunicação via questionário não está limitada às entrevistas pessoais, pois este instrumento pode ser utilizado também em entrevistas por telefone ou ser enviado pelo correio ou Internet.

De acordo com Kornhauser \& Sheatsley (1990), o procedimento de construção de um questionário deve obedecer seis etapas distintas: decisão sobre que informação deve ser procurada, definição sobre que tipo de questionário deve ser usado, redação de uma primeira versão, re-exame e 
revisão de questões, pré-teste e revisão do questionário e especificações dos processos para seu uso.

Mattar (1992) diz que, na definição do questionário, são importantes a sensibilidade, a experiência e o conhecimento das opções de como se perguntar. Também cita que a construção do questionário é um processo cíclico e interativo, já que o pesquisador deve testá-lo muitas vezes, até que ele esteja apropriadamente refinado para a aplicação.

Segundo Mattar (1996), a pesquisa descritiva é usada quando o propósito for de:

- descrever as características de grupos,

- estimar a proporção de elementos numa população específica, que tenham determinadas características ou comportamentos,

- descobrir ou verificar a existência de relação entre as variáveis.

\subsection{Análise estatística dos dados}

Kazmier (1982) diz que, para se definir o intervalo de confiança (IC) para a média populacional quando se desconhece o desvio padrão da população, o erro padrão da média pode ser estimado usando-se o desvio padrão da amostra como um estimador do desvio padrão da população. Assim, a form. (13) define o erro padrão estimado da média é:

$$
s_{x}=s \cdot n^{-1 / 2}
$$

com: 


$$
\begin{aligned}
& \mathrm{s}_{\mathrm{x}}=\text { erro padrão estimado da média } \\
& \mathrm{s}=\text { desvio padrão da amostra } \\
& \mathrm{n}=\text { número de amostras }
\end{aligned}
$$

Quando se trata de uma população finita, inclui-se na fórmula anterior um fator de correção. Esta correção será insignificante e poderá ser omitida sempre que o número de amostras for menor do que $5 \%$ da população. Logo, a form. (14) define o erro padrão da média quando se inclui o fator de correção finita é:

$$
s_{x}=s \cdot n^{-1 / 2} \cdot\left[(N-n) \cdot(N-1)^{-1}\right]^{1 / 2}
$$

onde:

$$
\mathrm{N} \text { = número total da população, quando finita }
$$

O autor ainda ressalta que, baseando-se no Teorema do Limite Central, a distribuição de amostragem da média se aproxima da forma da distribuição normal e como regra, considera-se tal fato como amostras iguais ou maiores de trinta.

O intervalo de confiança (IC) que contém a média populacional, considerando-se uma distribuição normal, é calculado pela eq. (15):

$$
I C=X \pm z \cdot s_{x}
$$

com:

$$
\begin{aligned}
& X=\text { média da amostra } \\
& Z \text { = número de unidades de desvios padrões a partir da média }
\end{aligned}
$$


Para o cálculo de diferenças entre médias populacionais, o autor instrui para a utilização da eq. (16), para um dado intervalo de confiança, caso as amostras seja iguais ou maiores de trinta:

$$
D_{1-2}=\left(X_{1}-X_{2}\right) \pm z \cdot\left[\left(s_{1} \cdot n_{1}{ }^{-1}\right)^{2}+\left(s_{2} \cdot n_{2}{ }^{-1}\right)^{2}\right]^{1 / 2}
$$

com:

$$
\begin{aligned}
& \mathrm{D}_{1-2}=\text { diferença entre médias populacionais } 1 \text { e } 2 \\
& \mathrm{X}_{1}=\text { média da } 1^{\mathrm{a}} \text { população } \\
& \mathrm{X}_{2}=\text { média da } 2^{\mathrm{a}} \text { população } \\
& \mathrm{s}_{1}=\text { desvio padrão da } 1^{\mathrm{a}} \text { população } \\
& \mathrm{n}_{1}=\text { número de amostras da } 1^{\mathrm{a}} \text { população } \\
& \mathrm{s}_{2}=\text { desvio padrão da } 2^{\mathrm{a}} \text { população } \\
& \mathrm{n}_{2}=\text { número de amostras da } 2^{\mathrm{a}} \text { população }
\end{aligned}
$$

Quando as amostras são menores de trinta, é apropriado que se use a distribuição $t$ de Student, conforme a eq. (17):

$$
\mathrm{D}_{1-2}=\left(\mathrm{X}_{1}-\mathrm{X}_{2}\right) \pm t\left(\mathrm{n}_{1}+\mathrm{n}_{2}-2\right) \cdot\left[\left(\mathrm{s}_{1} \cdot \mathrm{n}_{1}{ }^{-1}\right)^{2}+\left(\mathrm{s}_{2} \cdot \mathrm{n}_{2}{ }^{-1}\right)^{2}\right]^{1 / 2}
$$

com:

$$
\begin{aligned}
t\left(\mathrm{n}_{1}+\mathrm{n}_{2}-2\right)= & \text { número de unidades de desvios padrões a partir da média em } \\
& \text { distribuição } t \text { de Student }
\end{aligned}
$$




\section{MATERIAL E MÉTODOS}

Grande parte da bibliografia disponível e que trata de desempenho operacional de equipamentos motorizados agrícolas, trabalha com capacidades efetivas, capacidades e eficiências operacionais. Contudo, para alicerçar os gestores de frotas canavieiras de indicadores com maior aplicabilidade gerencial e de planejamento, tanto nos níveis operacional, como no tático e no estratégico, fez-se necessário propor a criação de indicadores de desempenho específicos.

\subsection{Proposição dos indicadores}

Esta proposição baseou-se na bibliografia mas, fundamentalmente, na interação com as empresas durante a fase de teste piloto dos questionários, que será detalhada adiante.

Dados os diferentes enfoques em que há interesse em se avaliar comparativamente uma frota canavieira, os indicadores sugeridos foram 
divididos em dois grupos, quais sejam: Indicadores de Avaliação de Desempenho e Indicadores Analítico-descritivos.

O primeiro grupo propõe indicadores que sirvam para, comparativamente com as demais empresas do segmento canavieiro, classificar a gestão da frota nos seus fundamentos. Por exemplo, um indicador de produtividade de determinado tipo de equipamento de uma agroindústria pretende mostrar aos gestores de frota como esta empresa se posiciona competitivamente perante as demais. Este grupo compreende os seguintes indicadores: Indicadores Operacionais, Indicadores de Dimensionamento e Indicadores de Consumo de Insumos.

O segundo grupo de indicadores, os Analítico-descritivos, pretende mostrar aos gestores de frotas canavieiras quais as tendências tecnológicas, econômicas e estratégicas que as agroindústrias canavieiras como um todo estão seguindo no tocante à gestão de suas frotas. Desta forma, não há o intuito, neste grupo, de se classificar qualitativa ou quantitativamente uma empresa em especial. Os indicadores que fazem parte deste rol são: Indicadores de Idade e Indicadores de Estratégia.

\subsubsection{Indicadores de avaliação de desempenho}




\subsubsection{Indicadores operacionais}

Francischini (1998) afirma que, numa visão abrangente, produtividade pode ser definida como uma relação entre um resultado e um esforço. Os indicadores operacionais mostrados neste estudo têm por função relacionar massas transportadas, carregadas ou colhidas (resultados) com equipamentos alocados por período de tempo (esforços).

\subsection{Produtividade média dos caminhões canavieiros - PMC}

Este indicador calcula a produção média de cada caminhão canavieiro por dia efetivo de safra por distância das glebas à indústria. Ele possibilita avaliar globalmente a produtividade do sistema de transporte de cana por caminhões da empresa em questão, independentemente da modalidade, considerando suas especificidades, frente às demais empresas do mercado, posicionando-a competitivamente. É obtido pela eq. (18):

$\mathrm{PMC}=\mathrm{PTT} .(\mathrm{CCA} . \mathrm{DEF} . \mathrm{DMF})^{-1}$

onde:

PTT = Massa total de cana transportada na safra $(t)$

$\mathrm{CCA}=$ Número de caminhões canavieiros próprios e alugados empregados na safra

DEF $=$ Número de dias efetivos da safra

DMF = Distância média das glebas à indústria $(\mathrm{km})$ 


\subsection{Cana carregada por carregadora por dia efetivo de safra - CCD}

Este índice apura a produção média por dia efetivo de safra de cada carregadora própria. É calculado pela eq. (19):

$C C D=C C P \cdot(C R \cdot D E F)^{-1}$

onde:

$\mathrm{CCP}=$ Massa total de cana carregada por carregadoras próprias na safra $(\mathrm{t})$

$\mathrm{CR}$ = Número de carregadoras de cana próprias

\subsection{Cana colhida por colhedora de cana por dia efetivo de safra - CPD}

Indicador que apura a produção média por dia efetivo de safra de cada colhedora de cana própria. É conhecido através da form. (20):

$\mathrm{CPD}=\mathrm{CPI} \cdot(\mathrm{CLP} \cdot \mathrm{DEF})^{-1}$

onde:

$\mathrm{CPI}=$ Massa total de cana colhida por colhedoras próprias na safra $(\mathrm{t})$

CLP $=$ Número de colhedoras próprias de cana picada

\subsection{Cana colhida por cortadora por dia efetivo de safra - CID}

Indicador que apura a produção média por dia efetivo de safra de cada cortadora automotriz de cana inteira própria. É obtido pela eq. (21):

$\mathrm{CID}=\mathrm{CCI} \cdot(\mathrm{CLI} \cdot \mathrm{DEF})^{-1}$ 
onde:

$\mathrm{CCl}=$ Massa total de cana inteira colhida por colhedoras próprias na safra $(\mathrm{t})$

$\mathrm{CLI}=$ Número de colhedoras próprias de cana inteira

\subsubsection{Indicador de dimensionamento}

Este grupo de indicadores tem por função auxiliar e avaliar o dimensionamento da frota das empresas, tanto no contexto global como em relação aos diferentes tipos de equipamentos que a compõem.

\subsection{Equipamentos motorizados por área de cana colhida - EMC}

Este indicador ilustra, globalmente, o número de equipamentos motorizados (próprios e alugados) necessários para atender a $10^{3}$ ha de área colhida e é calculado pela eq. (22).

$\mathrm{EMC}=\left(\mathrm{EMT} \cdot 10^{3}\right) \cdot \mathrm{HCC}^{-1}$

onde:

EMT = Número de equipamentos motorizados próprios e alugados na safra $\mathrm{HCC}=$ Área total de cana colhida na safra ( ha ) 


\subsubsection{Indicadores de consumo de insumos}

Este grupo visa atender ao Planejamento de Gastos e a Provisão Orçamentária das empresas, além de aferir e avaliar as despesas realizadas pela frota. No primeiro caso, auxilia os gestores das empresas a estimarem quanto irão despender de insumos com sua frota no exercício seguinte a partir de determinadas características conhecidas. No segundo caso, definem um valor médio aceitável de consumo dos insumos e, caso o indicador da empresa esteja significativamente discrepante da média, ações devem ser tomadas para preservar o indicador, caso seja positivo, ou para contorná-lo, caso seja negativo.

\subsection{Consumo de combustível ponderado por distância média - CDM}

Este indicador calcula o volume de combustível de motores de ciclo Diesel consumido por unidade de área ocupada com cana na safra conforme a distância média das glebas à indústria $\left(\mathrm{l} . \mathrm{km} \cdot \mathrm{ha}^{-1}\right)$. A área com cana é caracterizada pela soma da área de colheita atendida por frota própria com a área de plantio na safra. O equacionamento é o seguinte, envolvendo as eq. (23) e (24):

$\mathrm{CDM}=\mathrm{OD} \cdot \mathrm{DMF} \cdot\left\{\left[(\mathrm{HCC} \cdot \mathrm{IVT}) \cdot 10^{-2}\right]+\mathrm{HPL}\right\}^{-1}$

com:

IVT $=\left(\mathrm{PTP} \cdot \mathrm{PTT}^{-1}\right) \cdot 10^{2}$

onde:

OD = Volume de combustível de motores de ciclo Diesel consumido no ano (I) 
HCC = Área total de colheita ( ha )

IVT = Índice de Verticalização do Transporte de Cana ( \% )

$\mathrm{HPL}=$ Área de cana plantada ( ha )

DMF = Distância média das glebas à indústria $(\mathrm{km})$

PTP $=$ Massa total de cana transportada na safra por veículos próprios $(\mathrm{t})$

PTT = Massa total de cana transportada na safra $(t)$

\subsection{Motores retificados no ano - MRA}

Demonstra o porcentual de motores retificados no ano em relação à quantidade de equipamentos motorizados próprios, determinado pela eq. (25):

$M R A=(M R \cdot E M) \cdot 10^{2}$

onde:

$\mathrm{MR}=$ Número de motores retificados no ano

$E M=$ Número de equipamentos motorizados próprios

\subsubsection{Indicadores analítico-descritivos}




\subsubsection{Indicadores de idade}

São aqueles indicadores que buscam obter informações que subsidiem políticas e programas de renovação de frotas das empresas.

\subsection{Idade média dos equipamentos automotrizes - IEA}

Este indicador aponta a idade média ponderada (anos) dos equipamentos automotrizes próprios, através da eq. (26):

$I E A=\left[\sum_{i=0}^{n}(i \cdot E A I)\right] \cdot Q^{-1}$

onde:

$\mathrm{i}=$ idade $($ anos $)$

$\mathrm{n}$ = idade máxima existente dentre os equipamentos automotrizes próprios da frota

$\mathrm{EAI}=$ Número de equipamentos automotrizes da idade $\mathrm{i}$

QEA = Número total de equipamentos automotrizes

\subsection{Idade média dos veículos - IVE}

O indicador apresenta a idade média ponderada (anos) dos veículos próprios, obtido pela eq. (27): 
$\operatorname{IVE}=\left[\sum_{i=0}^{n}(\mathrm{i} \cdot \mathrm{VI})\right] \cdot \mathrm{QV}^{-1}$

onde:

$\mathrm{i}=$ idade $($ anos $)$

$\mathrm{n}$ = idade máxima existente dentre os veículos próprios da frota

$\mathrm{VI}=$ Número de veículos da idade $\mathrm{i}$

QV = Número total de veículos

\subsection{Idade média das máquinas - IMA}

O indicador apresenta a idade média ponderada (anos) de máquinas próprias e é obtido pela eq. (28):

IMA $=\left[\sum_{i=0}^{n}(i \cdot E M I)\right] \cdot \mathrm{QMA}^{-1}$

onde:

$\mathrm{i}=$ idade (anos)

$\mathrm{n}=$ idade máxima existente dentre as máquinas próprias da frota

$\mathrm{EMI}$ = Número de máquinas da idade $\mathrm{i}$

QMA = Número total de máquinas

\subsubsection{Indicadores de estratégia}


Este grupo de indicadores tem por função mostrar posicionamentos estratégicos que as agroindústrias canavieiras estão adotando e que interferem na posse, emprego e manutenção de suas frotas.

\subsection{Terceirização dos equipamentos motorizados - TMT}

Este indicador apresenta a participação dos equipamentos motorizados terceirizados (ou alugados) frente a toda a frota que atua na empresa e é obtido pela eq. (29):

$\mathrm{TMT}=\left(\mathrm{QTT} \cdot 10^{2}\right) \cdot \mathrm{QTE}^{-1}$

onde:

QTT = Número de equipamentos motorizados terceirizados

QTE = Número total de equipamentos motorizados presentes

\subsection{Plantio mecanizado de cana - PMN}

O indicador apresenta a representatividade (\%) do plantio mecanizado dentre todo o plantio realizado pela empresa e é obtido pela eq. (30):

$\mathrm{PMN}=\left(\mathrm{APM} \cdot 10^{2}\right) \cdot \mathrm{HPL}^{-1}$

onde:

APM = Área de plantio mecanizado (ha) 


\subsection{Colheita mecanizada de cana - CMC}

O indicador mostra a participação (\%) da colheita mecanizada (via colhedoras automotrizes) frente à área total de colheita da empresa e é obtido pela eq. (31):

$\mathrm{CMC}=(\mathrm{ACM} / \mathrm{HCC}) \cdot 10^{2}$

onde:

$\mathrm{ACM}=$ Área de colheita mecanizada (ha)

\subsection{Sistema de coleta de informações}

As informações empregadas para a elaboração do presente estudo foram obtidas através de pesquisa de auto-preenchimento, utilizando-se de questionários enviados eletronicamente (e-mail) e por correio, para averiguação

dos indicadores sugeridos, bem como para análise das empresas participantes. A opção pelos questionários deveu-se ao elevado número de agroindústrias canavieiras existentes no Brasil e dos recursos disponíveis.

A partir da relação total de usinas e destilarias constantes nos Anuário Centro-sul (1998) e Anuário Norte/nordeste (1998), foram encontradas 226 empresas do Centro-sul e 97 empresas do Norte/Nordeste do país. Logo, o tamanho inicial da população desta pesquisa ficou definido pela soma das agroindústrias canavieiras descritas em ambas as publicações, ou seja, 323 unidades. 


\subsubsection{Instrumento da coleta de dados}

O instrumento da coleta de dados utilizado nesta pesquisa foi 0 questionário. Adotando as posições de Kornhauser \& Sheatsley (1990) e Mattar (1992), o questionário desta pesquisa foi construído com linguagem acessível aos responsáveis pelo fornecimento das informações, demandando a existência de nível básico de controle nas empresas pesquisadas, ou seja, um controle de estoque (ou almoxarifado), um inventário da frota e um controle da produção dos equipamentos ligados à colheita e plantio de cana.

Somente foram solicitadas informações concretas da frota e de sua operação para cada empresa inquirida, já que os indicadores seriam calculados posteriormente pelo pesquisador.

Desta forma, pretendeu-se facilitar o preenchimento do questionário e obter

maior confiabilidade nas respostas dadas, pois cada empresa não saberia o resultado final de cada indicador, impossibilitando-a de conhecer sua classificação.

Para obter maior índice de respostas desta pesquisa, ela teve sua amplitude ampliada com perguntas referentes à área agronômica das empresas. Contudo, este trabalho não se ateve a este segmento do questionário. 


\subsubsection{Teste piloto}

Determinadas as perguntas do questionário e definida a população, foi realizado um teste piloto com a finalidade de verificar a consistência e confiabilidade das questões. Este piloto foi aplicado numa amostra de 36 agroindústrias canavieiras paulistas, escolhidas aleatoriamente, em julho de 1997, com dados referentes à safra 1996/1997.

Findo o teste, as correções necessárias foram realizadas para se obter a versão final do questionário.

\subsubsection{Envio do questionário}

O questionário foi enviado, por três anos seguidos, a partir de 1998, à população de agroindústrias canavieiras desta pesquisa. Foram remetidos tanto pelo correio convencional - em formato papel - como por correio eletrônico - num arquivo de planilha eletrônica Microsoft Excel - e foram dirigidos aos gerentes e/ou diretores agrícolas das empresas cadastradas.

\subsection{Retorno dos resultados às agroindústrias canavieiras}

Os resultados encontrados pelas pesquisas foram tabulados, compilados e editados. As técnicas utilizadas no tratamento estatístico dos dados foram determinadas pelos objetivos e pelas características das variáveis envolvidas. 
A cada compilação anual dos dados, calculavam-se os indicadores, que eram editados e publicados num anuário que, posteriormente, era distribuído dentre todas as agroindústrias cadastradas, independentemente de terem colaborado no envio de questionários ou não. Desta forma, foram publicados: Nunes Júnior et al. (1998), Nunes Júnior et al. (1999) e Nunes Júnior et al. (2000).

O intuito foi o de instigar e motivar as agroindústrias brasileiras a experimentarem e adotarem o emprego dos indicadores sugeridos na sua gestão, o que era um objetivo deste trabalho. Também, com esta divulgação, ficaria mais fácil obter a contribuição dos questionários respondidos no ano seguinte.

A edição dos indicadores de desempenho nas publicações supracitadas obedeceu igualmente o critério de provocar os gestores das frotas canavieiras para melhorarem seus resultados, visando avaliar a contribuição que a ferramenta gerencial de uso dos indicadores traria às próprias empresas optantes.

A Figura 4 ilustra um exemplo de indicador divulgado via publicação às agroindústrias canavieiras brasileiras, oriundo deste trabalho, em 1998.

Resultados de PMC:

\begin{tabular}{cccccc}
\hline Classificação & \multicolumn{2}{c}{ CENTRO-SUL } & \multicolumn{2}{c}{ NORDESTE/LESTE } & \\
Das & Faixa de & Freqüência de & Faixa de & Freqüência de & Esta \\
Empresas & Resultado & Empresas (\%) & Resultado & Empresas (\%) & Empresa \\
\hline ÓTIMA & 12,4 a 30,2 & 20,4 & 9,8 a 13,0 & 23,1 & \\
BOA & 9,0 a 12,3 & 18,5 & 8,0 a 9,7 & 38,5 & \\
REGULAR & 4,8 a 8,9 & 31,5 & 5,4 a 7,9 & 23,1 & \\
RUIM & abaixo de 4,8 & 29,6 & abaixo de 5,4 & 15,4 & \\
\hline
\end{tabular}

Figura 4 - Exemplo de apresentação de resultados da produtividade média de caminhões canavieiros (PMC) em Nunes Júnior et al. (1998). 


\subsection{Tratamento e análise dos dados}

Utilizou-se da análise descritiva no tratamento dos dados. Conforme recomendado por Mattar (1996), para as amostras das populações de cada indicador, foram calculados médias, desvios padrão, valores mínimos e valores máximos. Posteriormente, foram calculadas as estimativas populacionais de cada indicador.

Como este trabalho se ateve numa população finita, adotou-se, para cálculo dos erros padrão das médias, a fórmula com o fator de correção para população finita, conforme sugerido por Kazmier (1982).

Os indicadores de desempenho deste trabalho consideraram um grau de confiança de $95 \%$. Com isso, o valor de $Z$ no cálculo dos intervalos de confiança foi de 1,96 .

Além de calcular as médias populacionais, as amostras de cada indicador foram subdivididas em 2 grupos: o primeiro continha somente os dados das dezesseis agroindústrias que participaram igualmente do trabalho nas suas três safras, enquanto o segundo era composto das demais empresas que não foram assíduas na participação ao longo das três safras. $O$ intuito foi o de apurar se 0 grupo das empresas assíduas - fato que deve demonstrar seu maior interesse no gerenciamento através dos indicadores - teve suas médias de resultados dos indicadores superiores ao grupo das demais, não assíduas.

Para o cálculo de diferenças entre médias populacionais, adotaram-se os procedimentos apresentados por Kazmier (1982) tanto para amostras iguais ou 
maiores de 30 como para as menores deste limite, como ocorreram no caso das sub-amostras compostas pelas dezesseis empresas que foram assíduas na participação nas três safras. Nesta última situação, quando se empregou a distribuição $t$ de Student, também o IC considerado foi de 95\%.

Para alguns indicadores, também foram calculadas diferenças entre médias de safras subseqüentes, visando apurar a evolução temporal dos resultados.

Todo o tratamento estatístico dos dados foi efetuado no sistema Microsoft Excel 7.0. Todos os questionários recebidos ou já se encontravam no formato MS Excel ou eram digitados neste software. Nos APÊNDICES há 2 exemplos de modelos completos de questionário. As informações advindas do estudo da relação da frota, que também foram solicitadas às agroindústrias pelos questionários, geraram novas planilhas. As planilhas primárias, com os dados no formato do questionário, geravam planilhas secundárias, onde a análise estatística foi feita. 


\section{RESULTADOS E DISCUSSÃO}

\subsection{Exposição dos dados}

Quando do envio dos questionários, foi firmado um compromisso entre as agroindústrias que participaram e o autor de não divulgação nominal dos dados referentes a cada uma das empresas. Desta forma, as informações aqui apresentadas o são de forma agregada, sem a identificação individual de cada empresa pesquisada.

\subsection{Representatividade das respostas aos questionários}

Com o objetivo de coletar os dados referentes às safras 1997/1998, 1998/1999 e 1999/2000, foram enviados anualmente, durante os meses de Março de 1998, 1999 e 2000, 323 questionários para cada uma das empresas agroindustriais canavieiras existentes no país.

O retorno dos questionários respondidos obedeceu à distribuição apresentada na Tabela 1, com os nomes da empresas estando descritos em ANEXO A, ANEXO B e ANEXO C: 
Tabela 1. Participação de empresas agroindustriais canavieiras respondendo aos questionários da pesquisa deste estudo.

\begin{tabular}{cccc}
\hline Safras & $\begin{array}{c}\text { Número de usinas } \\
\text { existentes }\end{array}$ & $\begin{array}{c}\text { Número de questionários } \\
\text { respondidos }\end{array}$ & $\begin{array}{c}\text { Participações } \\
(\%)\end{array}$ \\
\hline $1997 / 1998$ & 323 & 67 & 20,74 \\
$1998 / 1999$ & 323 & 73 & 22,60 \\
$1999 / 2000$ & 323 & 73 & 22,60 \\
\hline
\end{tabular}

É importante frisar que somente dezesseis agroindústrias igualmente participaram com seus questionários respondidos nas três safras estudadas, consolidando uma parcela que variou entre 21,92 a $23,88 \%$ das amostras anuais obtidas de empresas.

Para efeito da representatividade, em termos de moagem de cana-deaçúcar, das agroindústrias que contribuíram com os questionários para a safra 1997/1998, obteve-se $32,3 \%$ do total de cana moída no período no Brasil, conforme comparação com montante expresso em União das Agroindústrias Canavieiras do Estado de São Paulo - UNICA (2000). Já a representatividade em 1998/1999 foi de $38,2 \%$ da cana moída no país, enquanto que a de $1999 / 2000$ foi de $28,7 \%$ da cana moída no Brasil, também conforme comparação com UNICA (2000).

Para se obter cada indicador estudado neste trabalho, perguntas específicas do questionário deveriam ser respondidas, implicando que cada indicador necessitou de análise estatística individualizada. $O$ fato de uma 
determinada empresa ter respondido o questionário não implicou que tenha respondido a todas as questões necessárias para compor cada um dos indicadores, visto que alguns questionários vieram incompletos.

\subsection{Indicadores de avaliação de desempenho}

\subsubsection{Indicadores operacionais}

\subsubsection{Produtividade média dos caminhões canavieiros - PMC}

A Tabela 2 apresenta os resultados do PMC para as três safras pesquisadas.

Tabela 2. Produtividade média dos caminhões canavieiros (t.dia.caminhão-1 $\mathrm{km}^{-1}$ ) ao longo de três safras referente a todas as agroindústrias canavieiras amostradas.

\begin{tabular}{cccccc}
\hline Safras & $\begin{array}{c}\text { Tamanho das } \\
\text { Amostras }\end{array}$ & Médias & $\begin{array}{c}\text { Desvios } \\
\text { Padrão }\end{array}$ & Mínimos & Máximos \\
& & & & & \\
\hline $1997 / 1998$ & 67 & 9,06 & 6,42 & 1,18 & 35,28 \\
$1998 / 1999$ & 71 & 9,45 & 6,65 & 2,00 & 41,05 \\
$1999 / 2000$ & 57 & 10,55 & 10,68 & 0,66 & 74,58
\end{tabular}

Nota-se pela representatividade dos desvios padrões frente às médias a grande variabilidade deste indicador, que é esperada em função do enfoque 
generalista que apresenta, relacionando as produções médias diárias dos caminhões canavieiros, independentemente das combinações de veículos de carga empregadas (caminhões "solteiros", "romeu-julieta", "treminhão", "rodotrem" etc), com a duração da safra e a distância média entre os canaviais e a indústria.

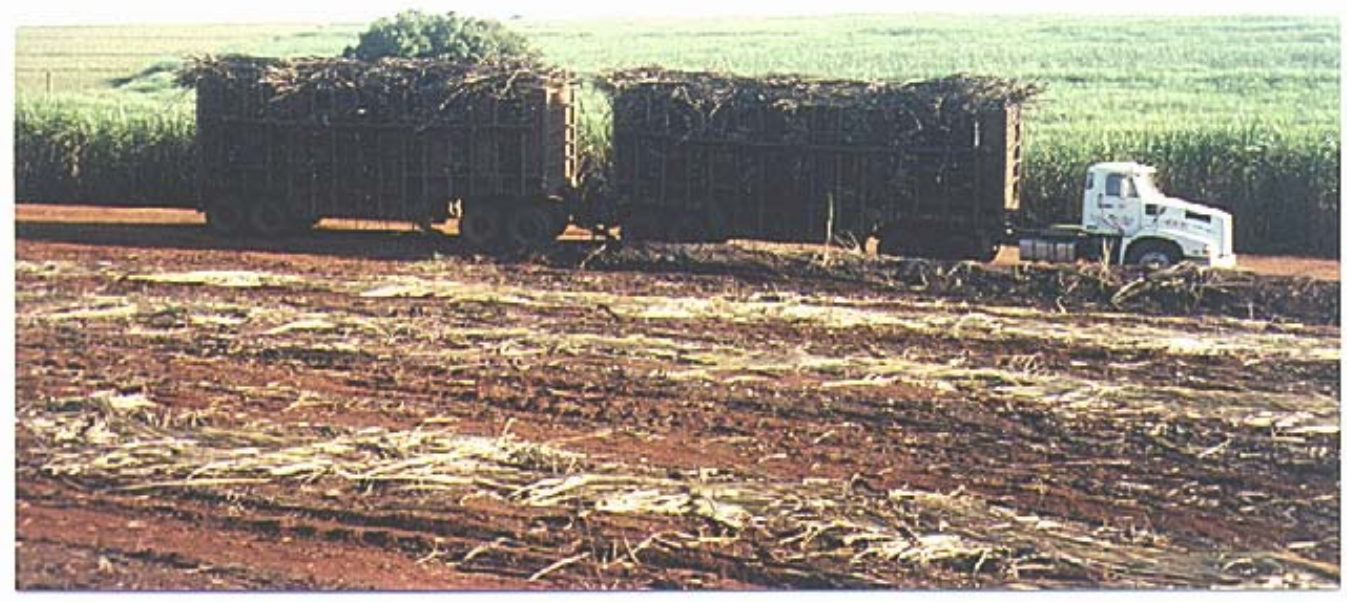

Figura 5 - Combinação "rodotrem" canavieiro para transporte de cana inteira. 


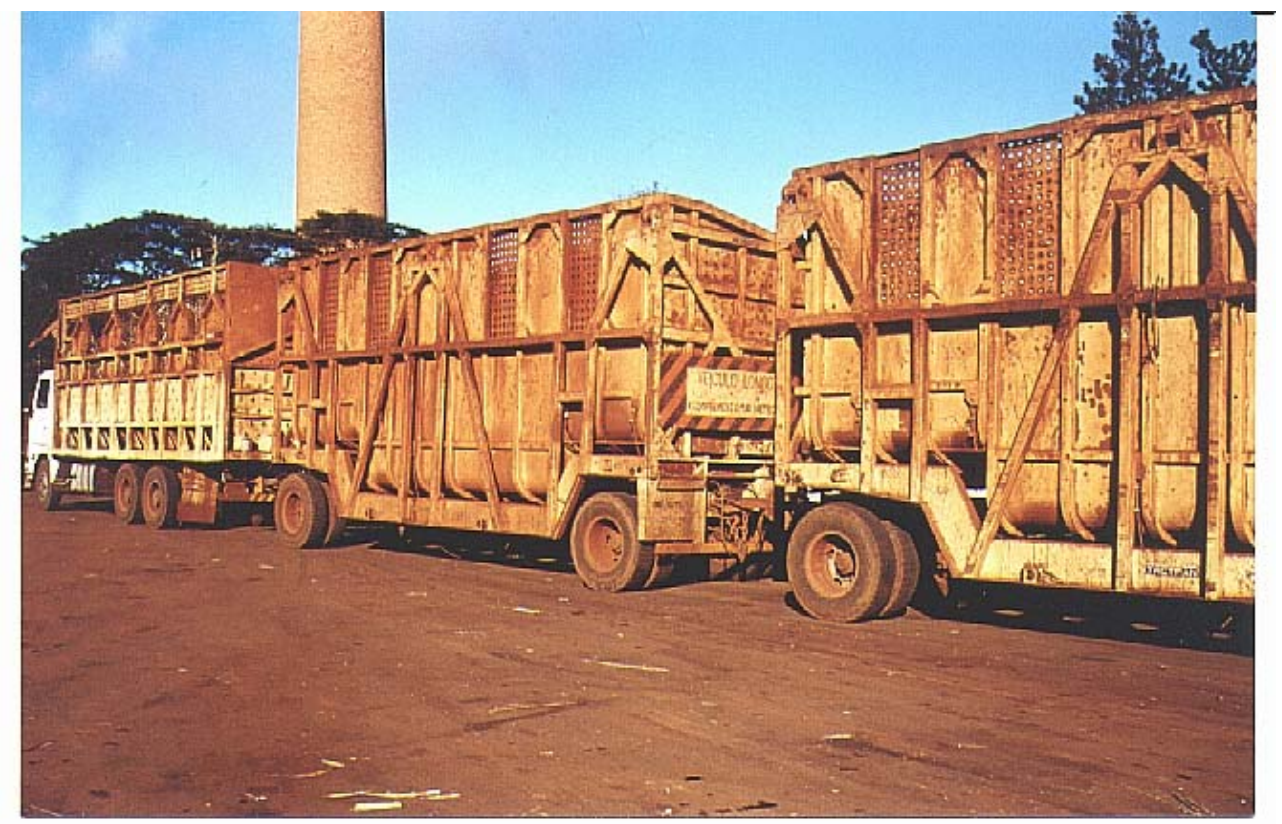

Figura 6 - Combinação "treminhão" para transporte de cana picada.

A faixa de valores definida acima do menor resultado máximo $(35,28$ em 1997/1998) pode ser considerada como uma meta a ser buscada pelas empresas do setor, enquanto que a faixa definida abaixo do maior resultado mínimo $(2,00$ em 1998/1999) pode ser assumida como a ocupada pelas piores empresas no tocante a este indicador.

Considerando-se um intervalo de confiança de 95\%, a Tabela 3 apresenta as estimativas para as populações totais de empresas das três safras. 
Tabela 3. Estimativas populacionais com intervalo de confiança de $95 \%$ para produtividade média dos caminhões canavieiros (t.dia.caminhão-1 $\mathrm{km}^{-1}$ ) ao longo de três safras.

\begin{tabular}{cccc}
\hline Safras & $\begin{array}{c}\text { Tamanho das } \\
\text { Amostras }\end{array}$ & $\begin{array}{c}\text { Erros Padrão } \\
\text { das Médias }\end{array}$ & $\begin{array}{c}\text { Valores Médios } \\
\text { das Populações }\end{array}$ \\
\hline $1997 / 1998$ & 67 & 0,70 & 7,69 a 10,43 \\
$1998 / 1999$ & 71 & 0,70 & 8,08 a 10,82 \\
$1999 / 2000$ & 57 & 1,29 & 8,03 a 13,07 \\
\hline
\end{tabular}

Quando apenas as dezesseis empresas que participaram das pesquisas das três safras consecutivas são consideradas, os resultados passam a ser os da Tabela 4 e os das demais empresas, excluindo-se estas dezesseis, são os da Tabela 5:

Tabela 4. Produtividade média dos caminhões canavieiros (t.dia.caminhão-1 $\mathrm{km}^{-1}$ ) referente somente às agroindústrias canavieiras amostradas que participaram igualmente das três safras pesquisadas.

\begin{tabular}{cccccc}
\hline Safras & $\begin{array}{c}\text { Tamanho das } \\
\text { Amostras }\end{array}$ & Médias & $\begin{array}{c}\text { Desvios } \\
\text { Padrão }\end{array}$ & Mínimos & Máximos \\
\hline $1997 / 1998$ & 16 & 9,43 & 6,18 & 2,85 & 21,29 \\
$1998 / 1999$ & 16 & 10,74 & 9,34 & 2,16 & 41,05 \\
$1999 / 2000$ & 13 & 13,55 & 18,88 & 2,58 & 74,58 \\
\hline
\end{tabular}


Tabela 5. Produtividade média dos caminhões canavieiros (t.dia.caminhão-1 $\mathrm{km}^{-1}$ ) referente somente às agroindústrias canavieiras amostradas que não participaram igualmente das três safras pesquisadas.

\begin{tabular}{cccccc}
\hline Safras & $\begin{array}{c}\text { Tamanho das } \\
\text { Amostras }\end{array}$ & Médias & $\begin{array}{c}\text { Desvios } \\
\text { Padrão }\end{array}$ & Mínimos & Máximos \\
\hline $1997 / 1998$ & 51 & 8,95 & 6,54 & 1,18 & 35,28 \\
$1998 / 1999$ & 55 & 9,08 & 5,70 & 2,00 & 28,75 \\
$1999 / 2000$ & 44 & 9,66 & 6,74 & 0,66 & 26,07 \\
\hline
\end{tabular}

Também nestas tabelas observou-se grande variabilidade do indicador, dadas as características já citadas para justificar a Tabela 2. Quando se testam as médias encontradas dentre as dezesseis empresas que participaram nas três pesquisas em comparação com as amostras das demais empresas em cada safra, têm-se os resultados da Tabela 6 .

Tabela 6. Diferenças com intervalo de confiança de $95 \%$ entre as médias da produtividade média dos caminhões canavieiros (t.dia.caminhão-1 $\mathrm{km}^{-1}$ ) das amostras referentes somente às agroindústrias canavieiras que participaram igualmente das três safras pesquisadas e das amostras das demais agroindústrias canavieiras.

\begin{tabular}{ccccc}
\hline Safras & $\begin{array}{c}\text { Médias das } \\
16 \text { empresas }\end{array}$ & $\begin{array}{c}\text { Médias das } \\
\text { demais empresas }\end{array}$ & Diferenças & $\begin{array}{c}\text { Médias } \\
\text { Maiores }\end{array}$ \\
\hline $1997 / 1998$ & 9,43 & 9,06 & $-3,10$ a 4,06 & indeterminável \\
$1998 / 1999$ & 10,74 & 9,45 & $-2,11$ a 4,69 & Indeterminável \\
$1999 / 2000$ & 13,55 & 10,55 & $-8,70$ a 12,70 & indeterminável \\
\hline
\end{tabular}


Com as diferenças das médias variando entre valores negativos e positivos, fica impossível determinar quais são as médias superiores nestes casos.

\subsubsection{Cana carregada por carregadora de cana por dia efetivo de safra - CCD}

Os resultados desse indicador encontram-se na Tabela 7.

Tabela 7. Massa de cana carregada por carregadora por dia efetivo de safra (t.dia.carregadora $^{-1}$ ) ao longo de três safras referente a todas as agroindústrias canavieiras amostradas.

\begin{tabular}{cccccc}
\hline \multirow{2}{*}{ Safras } & $\begin{array}{c}\text { Tamanhos das } \\
\text { Amostras }\end{array}$ & Médias & Desvios & Mínimos & Máximos \\
& & & Padrão & & \\
\hline $1997 / 1998$ & 65 & 320,20 & 125,56 & 40,88 & 674,54 \\
$1998 / 1999$ & 68 & 319,69 & 125,43 & 41,70 & 574,49 \\
$1999 / 2000$ & 56 & 316,64 & 152,68 & 40,58 & 701,35 \\
\hline
\end{tabular}

Este indicador, por retratar uma realidade mais específica, possui desvios padrões relativamente menores do que os do indicador PMC (produtividade média dos caminhões canavieiros).

A faixa de valores definida acima do menor resultado máximo $(574,49 \mathrm{em}$ 1998/1999) pode ser considerada como uma meta a ser buscada pelas empresas do setor, enquanto que a faixa definida abaixo do maior resultado mínimo $(40,58$ 
em 1999/2000) pode ser assumida como a ocupada pelas piores empresas no tocante a este indicador.

Considerando-se um intervalo de confiança de 95\%, a Tabela 8 apresenta as estimativas para as populações totais de empresas nas três safras.

Tabela 8. Estimativas populacionais com intervalo de confiança de $95 \%$ para cana carregada por carregadora por dia efetivo de safra (t.dia.carregadora ${ }^{-1}$ ) ao longo de três safras.

\begin{tabular}{cccc}
\hline Safras & $\begin{array}{c}\text { Tamanhos das } \\
\text { Amostras }\end{array}$ & $\begin{array}{c}\text { Erros Padrão } \\
\text { das Médias }\end{array}$ & $\begin{array}{c}\text { Valores Médios } \\
\text { das Populações }\end{array}$ \\
\hline $1997 / 1998$ & 65 & 13,94 & 292,88 a 347,52 \\
$1998 / 1999$ & 68 & 13,54 & 293,15 a 346,23 \\
$1999 / 2000$ & 56 & 18,58 & 280,22 a 353,06 \\
\hline
\end{tabular}

Quando apenas as dezesseis empresas que participaram das pesquisas das três safras consecutivas são consideradas, os resultados passam a ser os da Tabela 9, enquanto que os resultados das demais empresas encontram-se na Tabela 10: 
Tabela 9. Massa de cana carregada por carregadora por dia efetivo de safra $\left(\right.$ t.dia.carregadora $\left.^{-1}\right)$ referente somente às agroindústrias canavieiras amostradas que participaram igualmente das três safras pesquisadas.

\begin{tabular}{cccccc}
\hline Safras & $\begin{array}{c}\text { Tamanhos } \\
\text { das Amostras }\end{array}$ & Médias & $\begin{array}{c}\text { Desvios } \\
\text { Padrão }\end{array}$ & Mínimos & Máximos \\
\hline $1997 / 1998$ & 16 & 351,59 & 85,31 & 230,61 & 564,91 \\
$1998 / 1999$ & 16 & 366,21 & 82,16 & 241,44 & 543,57 \\
$1999 / 2000$ & 14 & 386,30 & 117,51 & 273,24 & 689,61 \\
\hline
\end{tabular}

Tabela 10. Massa de cana carregada por carregadora por dia efetivo de safra (t.dia.carregadora $^{-1}$ ) referente às demais agroindústrias canavieiras que não participaram igualmente das três safras pesquisadas.

\begin{tabular}{cccccc}
\hline Safras & $\begin{array}{c}\text { Tamanhos } \\
\text { das Amostras }\end{array}$ & Médias & $\begin{array}{c}\text { Desvios } \\
\text { Padrão }\end{array}$ & Mínimos & Máximos \\
\hline $1997 / 1998$ & 49 & 310,15 & 135,14 & 40,88 & 674,52 \\
$1998 / 1999$ & 52 & 305,37 & 133,40 & 41,70 & 574,49 \\
$1999 / 2000$ & 42 & 293,42 & 157,11 & 40,58 & 701,35 \\
\hline
\end{tabular}

Quando são testadas as médias encontradas dentre as dezesseis empresas que participaram nas três pesquisas em comparação com as demais empresas amostradas em cada safra, têm-se os resultados da Tabela 11. 
Tabela 11. Diferenças com intervalo de confiança de $95 \%$ entre as médias da cana carregada por carregadora por dia efetivo de safra (t.dia.carregadora $^{-1}$ ) das amostras referentes somente às dezesseis agroindústrias canavieiras que participaram igualmente das três safras pesquisadas e das demais agroindústrias participantes.

\begin{tabular}{ccccc}
\hline Safras & $\begin{array}{c}\text { Médias das } \\
16 \text { empresas }\end{array}$ & $\begin{array}{c}\text { Médias das } \\
\text { demais empresas }\end{array}$ & Diferenças & $\begin{array}{c}\text { Médias } \\
\text { Maiores }\end{array}$ \\
\hline $1997 / 1998$ & 351,59 & 310,15 & $-16,19$ a 99,07 & Indeterminável \\
$1998 / 1999$ & 366,21 & 305,37 & 5,38 a 116,30 & 16 empresas \\
$1999 / 2000$ & 386,30 & 293,42 & 13,78 a 171,98 & 16 empresas \\
\hline
\end{tabular}

Portanto, em duas safras foi possível diagnosticar, com 95\% de confiança, que houve superioridade no resultado médio das empresas assíduas em comparação com os das empresas não assíduas.

\subsubsection{Cana colhida por colhedora por dia efetivo de safra - CPD}

Os resultados do CPD encontram-se na Tabela 12. 
Tabela 12. Massa de cana colhida por colhedora por dia efetivo de safra (t.dia.colhedora $^{-1}$ ) ao longo de três safras referente a todas as agroindústrias canavieiras amostradas.

\begin{tabular}{cccccc}
\hline Safras & $\begin{array}{c}\text { Tamanhos das } \\
\text { Amostras }\end{array}$ & Médias & $\begin{array}{c}\text { Desvios } \\
\text { Padrão }\end{array}$ & Mínimos & Máximos \\
\hline $1997 / 1998$ & 19 & 339,98 & 257,64 & 5,29 & 1204,7 \\
$1998 / 1999$ & 26 & 370,64 & 132,09 & 130,86 & 787,40 \\
$1999 / 2000$ & 24 & 473,72 & 215,54 & 197,95 & 1231,11 \\
\hline
\end{tabular}

Este indicador, mesmo retratando uma situação mais específica, possui desvios padrões significativos, provavelmente por considerar uma grande diversidade de fabricantes e gerações de colhedoras, bem como grau de gerenciamento e uso das mesmas pelas empresas.

A faixa de valores definida acima do menor resultado máximo $(787,40 \mathrm{em}$ 1998/1999) pode ser considerada como uma meta a ser buscada pelas empresas do setor, enquanto que a faixa definida abaixo do maior resultado mínimo $(197,95$ em 1999/2000) pode ser assumida como a ocupada pelas piores empresas no tocante a este indicador.

Considerando-se um intervalo de confiança de 95\%, a Tabela 13 apresenta as estimativas para as populações totais de empresas nas três safras. 
Tabela 13. Estimativas populacionais com intervalo de confiança de $95 \%$ para cana colhida por colhedora por dia efetivo de safra (t.dia. colhedora $^{-1}$ ) ao longo de três safras.

\begin{tabular}{cccc}
\hline Safras & $\begin{array}{c}\text { Tamanhos das } \\
\text { Amostras }\end{array}$ & $\begin{array}{c}\text { Erros Padrão } \\
\text { das Médias }\end{array}$ & $\begin{array}{c}\text { Valores Médios } \\
\text { das Populações }\end{array}$ \\
\hline $1997 / 1998$ & 19 & 57,43 & 219,32 a 460,64 \\
$1998 / 1999$ & 26 & 24,88 & 319,39 a 421,89 \\
$1999 / 2000$ & 24 & 42,40 & 385,99 a 561,45 \\
\hline
\end{tabular}

Quando apenas as dezesseis empresas que participaram das pesquisas das três safras consecutivas são consideradas, os resultados passam a ser os da Tabela 14, ao passo que os resultados das demais empresas estão na Tabela 15:

Tabela 14. Massa de cana colhida por colhedora por dia efetivo de safra (t.dia.colhedora $^{-1}$ ) referente somente às dezesseis agroindústrias canavieiras amostradas que participaram igualmente das três safras pesquisadas.

\begin{tabular}{cccccc}
\hline Safras & $\begin{array}{c}\text { Tamanhos } \\
\text { das Amostras }\end{array}$ & Médias & $\begin{array}{c}\text { Desvios } \\
\text { Padrão }\end{array}$ & Mínimos & Máximos \\
\hline $1997 / 1998$ & 9 & 371,67 & 111,33 & 261,99 & 571,96 \\
$1998 / 1999$ & 11 & 413,24 & 76,00 & 297,36 & 523,04 \\
$1999 / 2000$ & 12 & 458,45 & 85,53 & 357,92 & 618,78 \\
\hline
\end{tabular}


Tabela 15. Massa de cana colhida por colhedora por dia efetivo de safra (t.dia.colhedora $^{-1}$ ) referente às demais agroindústrias canavieiras amostradas que não participaram igualmente das três safras pesquisadas.

\begin{tabular}{cccccc}
\hline \multirow{2}{*}{ Safras } & $\begin{array}{c}\text { Tamanhos } \\
\text { das Amostras }\end{array}$ & Médias & $\begin{array}{c}\text { Desvios } \\
\text { Padrão }\end{array}$ & Mínimos & Máximos \\
& & & & & \\
\hline $1997 / 1998$ & 10 & 324,75 & 294,06 & 5,29 & 1204,70 \\
$1998 / 1999$ & 15 & 354,94 & 146,09 & 130,86 & 787,40 \\
$1999 / 2000$ & 12 & 481,35 & 260,07 & 197,95 & 1231,11 \\
\hline
\end{tabular}

Quando são testadas as médias encontradas dentre as dezesseis empresas que participaram nas três pesquisas em comparação com as demais empresas em cada safra, têm-se os resultados da Tabela 16.

Tabela 16. Diferenças com intervalo de confiança de $95 \%$ entre as médias da cana colhida por colhedora por dia efetivo de safra (t.dia. colhedora $^{-1}$ ) das amostras referentes somente às dezesseis agroindústrias canavieiras que participaram igualmente das três safras pesquisadas e das demais agroindústrias que não participaram igualmente das três safras.

\begin{tabular}{ccccc}
\hline \multirow{2}{*}{ Safras } & Médias das & Médias das & & Médias \\
& 16 empresas & demais & Diferenças & Maiores \\
& & empresas & & \\
\hline $1997 / 1998$ & 371,67 & 324,75 & $-164,34$ a 258,18 & indeterminável \\
$1998 / 1999$ & 413,24 & 354,94 & $-32,79$ a 149,39 & Indeterminável \\
$1999 / 2000$ & 458,45 & 481,35 & $-186,81$ a 141,01 & indeterminável \\
\hline
\end{tabular}


Com as diferenças das médias variando entre valores negativos e positivos, fica impossível determinar quais são as médias superiores nestes casos.

\subsubsection{Cana colhida por cortadora de cana por dia efetivo de safra - CID}

Os resultados do CID estão ilustrados na Tabela 17.

Tabela 17. Massa de cana colhida por cortadora de cana por dia efetivo de safra (t.dia.colhedora $^{-1}$ ) ao longo de três safras referente a todas as agroindústrias canavieiras amostradas.

\begin{tabular}{lccccc}
\hline \multirow{2}{*}{ Safras } & $\begin{array}{c}\text { Tamanhos das } \\
\text { Amostras }\end{array}$ & Médias & $\begin{array}{c}\text { Desvios } \\
\text { Padrão }\end{array}$ & Mínimos & Máximos \\
\hline $1997 / 1998$ & 4 & 399,06 & 420,68 & 128,57 & 1026,5 \\
$1998 / 1999$ & 4 & 76,54 & 81,29 & 0,19 & 184,2 \\
$1999 / 2000$ & 1 & $*$ & $*$ & $*$ & $*$ \\
& \\
& & & & & \\
(1.935,82 t.dia.colhedora ${ }^{-1}$ )
\end{tabular}

Em função do pouco número de empresas com cortadoras de cana, chegando-se ao ponto de somente uma empresa em 73 amostradas em 1999/2000 ter este tipo de máquina em sua frota, não se fizeram as análises junto às dezesseis empresas que participaram das três safras consecutivas e nem tampouco junto às demais em separado. 
Mesmo assim, nota-se a forte tendência, dentre as agroindústrias pesquisadas, de abortar o emprego deste tipo de máquina. $E$ tal fato ocorre independentemente das vantagens que Magalhães \& Braunbeck (1998) apresentam para este processo de mecanização da colheita, ou seja, a cana inteira permite maior tempo de estocagem, menor infestação de fungos e independência entre o sistema de colheita e o de transporte, reduzindo os custos operacional e de capital.

A significativa diferença entre as médias de CPD e CID parece desencorajar as empresas de optarem por cortadoras, como confirma a pequena participação de empresas que as possuem, a partir da comparação entre as empresas amostradas que possuem cortadoras de cana (4 em 1997/1998, 4 em 1998/1999 e 1 em 1999/2000) contra as que possuem colhedoras de cana (19 em 1997/1998, 26 em 1998/1999 e 24 em 1999/2000).

Considerando-se um intervalo de confiança de 95\%, a Tabela 18 apresenta as estimativas para as populações totais de empresas nas três safras.

Tabela 18. Estimativas populacionais com intervalo de confiança de $95 \%$ para cana colhida por cortadora de cana por dia efetivo de safra (t.dia.colhedora ${ }^{-1}$ ) ao longo de três safras.

\begin{tabular}{cccc}
\hline Safras & $\begin{array}{c}\text { Tamanhos } \\
\text { das Amostras }\end{array}$ & $\begin{array}{c}\text { Erros Padrão } \\
\text { das Médias }\end{array}$ & $\begin{array}{c}\text { Valores Médios } \\
\text { das Populações }\end{array}$ \\
\hline $1997 / 1998$ & 4 & 57,43 & 219,32 a 460,64 \\
$1998 / 1999$ & 4 & 24,88 & 319,39 a 421,89 \\
$1999 / 2000$ & 1 & $*$ & $*$ \\
\hline
\end{tabular}




\subsubsection{Indicador de dimensionamento}

\subsubsection{Equipamentos motorizados por $10^{3}$ ha de cana cortada - EMC}

Pode-se acompanhar o perfil relativo ao dimensionamento das frotas amostradas através da Tabela 19.

Tabela 19. Número de equipamentos motorizados por $10^{3}$ ha de cana cortada (equipamento. $10^{-3}$ ha) ao longo de três safras referente a todas as agroindústrias canavieiras amostradas.

\begin{tabular}{cccccc}
\hline Safras & $\begin{array}{c}\text { Tamanhos das } \\
\text { Amostras }\end{array}$ & Médias & $\begin{array}{c}\text { Desvios } \\
\text { Padrão }\end{array}$ & Mínimos & Máximos \\
\hline $1997 / 1998$ & 66 & 16,29 & 8,55 & 4,04 & 52,10 \\
$1998 / 1999$ & 72 & 18,88 & 16,93 & 1,29 & 107,40 \\
$1999 / 2000$ & 69 & 20,54 & 26,69 & 1,40 & 189,98 \\
\hline
\end{tabular}

Este é mais um indicador generalista, o que explica os altos valores de desvios padrão obtidos. Ele engloba todos os equipamentos motorizados das frotas das empresas, desde moto-bombas e motores estacionários até veículos e máquinas.

A faixa de valores definida abaixo do maior resultado mínimo (4,04 em 1997/1998) pode ser considerada como uma meta a ser buscada pelas empresas do setor, enquanto que a faixa definida acima do menor resultado máximo $(52,10$ 
em 1997/1998) pode ser assumida como a ocupada pelas piores empresas no tocante a este indicador.

Considerando-se um intervalo de confiança de 95\%, a Tabela 20 apresenta as estimativas para as populações totais de empresas nas três safras.

Tabela 20. Estimativas populacionais com intervalo de confiança de $95 \%$ para equipamentos motorizados por $10^{3}$ ha de cana cortada (equipamento. $10^{-3}$ ha) ao longo de três safras.

\begin{tabular}{cccc}
\hline Safras & $\begin{array}{c}\text { Tamanhos } \\
\text { das Amostras }\end{array}$ & $\begin{array}{c}\text { Erros Padrão } \\
\text { das Médias }\end{array}$ & $\begin{array}{c}\text { Valores Médios } \\
\text { das Populações }\end{array}$ \\
\hline $1997 / 1998$ & 66 & 0,94 & 14,45 a 18,13 \\
$1998 / 1999$ & 72 & 1,76 & 15,43 a 22,33 \\
$1999 / 2000$ & 69 & 2,85 & 14,95 a 26,13 \\
\hline
\end{tabular}

Quando apenas as dezesseis empresas que participaram das pesquisas das três safras consecutivas são consideradas, os resultados passam a ser os da Tabela 21, ao passo que os resultados das demais empresas estão na Tabela 22: 
Tabela 21. Número de equipamentos motorizados por $10^{3}$ ha de cana cortada (equipamento. $10^{-3} \mathrm{ha}$ ) referente somente às dezesseis agroindústrias canavieiras amostradas que participaram igualmente das três safras pesquisadas.

\begin{tabular}{cccccc}
\hline Safras & $\begin{array}{c}\text { Tamanhos } \\
\text { das Amostras }\end{array}$ & Médias & $\begin{array}{c}\text { Desvios } \\
\text { Padrão }\end{array}$ & Mínimos & Máximos \\
& & & & & \\
\hline $1997 / 1998$ & 16 & 14,45 & 5,48 & 5,93 & 29,42 \\
$1998 / 1999$ & 16 & 16,57 & 10,01 & 3,22 & 42,66 \\
$1999 / 2000$ & 16 & 14,51 & 8,50 & 1,40 & 33,04 \\
\hline
\end{tabular}

Tabela 22. Número de equipamentos motorizados por $10^{3}$ ha de cana cortada (equipamento. $10^{-3}$ ha) referente às demais agroindústrias canavieiras amostradas que não participaram igualmente das três safras pesquisadas.

\begin{tabular}{cccccc}
\hline Safras & $\begin{array}{c}\text { Tamanhos } \\
\text { das Amostras }\end{array}$ & Médias & $\begin{array}{c}\text { Desvios } \\
\text { Padrão }\end{array}$ & Mínimos & Máximos \\
\hline $1997 / 1998$ & 50 & 16,49 & 8,21 & 4,04 & 52,10 \\
$1998 / 1999$ & 56 & 19,53 & 18,46 & 1,29 & 107,40 \\
$1999 / 2000$ & 53 & 22,35 & 29,93 & 3,85 & 189,98 \\
\hline
\end{tabular}

Quando são testadas as médias encontradas dentre as dezesseis empresas que participaram nas três pesquisas em comparação com as demais empresas em cada safra, têm-se os resultados da Tabela 23. 
Tabela 23. Diferenças com intervalo de confiança de 95\% entre as médias de equipamentos motorizados por $10^{3}$ ha de cana cortada (equipamento. $10^{-3}$ ha) das amostras referentes somente às dezesseis agroindústrias canavieiras que participaram igualmente das três safras pesquisadas e das demais agroindústrias que não participaram igualmente das três safras.

\begin{tabular}{ccccc}
\hline Safras & $\begin{array}{c}\text { Médias das } \\
16 \text { empresas }\end{array}$ & $\begin{array}{c}\text { Médias das } \\
\text { demais } \\
\text { empresas }\end{array}$ & Diferenças & $\begin{array}{c}\text { Médias } \\
\text { Menores }\end{array}$ \\
\hline $1997 / 1998$ & 14,45 & 16,49 & $-5,62$ a 1,54 & indeterminável \\
$1998 / 1999$ & 16,57 & 19,53 & $-9,95$ a 4,03 & Indeterminável \\
$1999 / 2000$ & 14,51 & 22,35 & $-17,06$ a 1,38 & indeterminável \\
\hline
\end{tabular}

Com as diferenças das médias variando entre valores negativos e positivos, fica impossível determinar quais são as médias superiores nestes casos.

\subsubsection{Indicadores de consumo de insumos}

\subsubsection{Consumo de combustível ponderado por distância média - CDM}

Os resultados do consumo de combustível ponderado por distância média estão apresentados na Tabela 24. 
Tabela 24. Consumo de combustível ponderado por distância média (I.km.ha $\left.{ }^{-1}\right)$ ao longo de três safras referente a todas as agroindústrias canavieiras amostradas.

\begin{tabular}{cccccc}
\hline Safras & Amostras & Médias & Desvios Padrão & Mínimos & Máximos \\
\hline $1997 / 1998$ & 67 & 14,14 & 11,28 & 3,05 & 57,05 \\
$1998 / 1999$ & 66 & 13,82 & 7,62 & 0,84 & 31,98 \\
$1999 / 2000$ & 55 & 18,24 & 15,45 & 2,19 & 74,58 \\
\hline
\end{tabular}

Novamente, depara-se com um indicador generalista, o que explica os altos valores de desvio padrão obtidos.

A faixa de valores definida abaixo do maior resultado mínimo $(3,05 \mathrm{em}$ 1997/1998) pode ser considerada como uma meta a ser buscada pelas empresas do setor, enquanto que a faixa definida acima do menor resultado máximo $(31,98$ em 1998/1999) pode ser assumida como a ocupada pelas piores empresas no tocante a este indicador.

Considerando-se um intervalo de confiança de 95\%, a Tabela 25 apresenta as estimativas para as populações totais de empresas nas três safras. 
Tabela 25. Estimativas populacionais com intervalo de confiança de 95\% para consumo de combustível ponderado por distância média $\left(\mathrm{I} . \mathrm{km} . \mathrm{ha} \mathrm{H}^{-1}\right)$ ao longo de três safras.

\begin{tabular}{cccc}
\hline Safras & $\begin{array}{c}\text { Tamanhos } \\
\text { das } \\
\text { Amostras }\end{array}$ & $\begin{array}{c}\text { Erros Padrão } \\
\text { das Médias }\end{array}$ & $\begin{array}{c}\text { Valores Médios } \\
\text { das Populações }\end{array}$ \\
\hline $1997 / 1998$ & 67 & 1,23 & 11,73 a 16,55 \\
$1998 / 1999$ & 66 & 0,84 & 12,18 a 15,46 \\
$1999 / 2000$ & 55 & 1,90 & 14,51 a 21,97 \\
\hline
\end{tabular}

Quando apenas as dezesseis empresas que participaram das pesquisas das três safras consecutivas são consideradas, os resultados passam a ser os da Tabela 26, ao passo que os resultados das demais empresas estão na Tabela 27:

Tabela 26. Consumo de combustível ponderado por distância média (I.km.ha- $\left.{ }^{-1}\right)$ referente somente às dezesseis agroindústrias canavieiras amostradas que participaram igualmente das três safras pesquisadas.

\begin{tabular}{cccccc}
\hline Safras & $\begin{array}{c}\text { Tamanhos das } \\
\text { Amostras }\end{array}$ & Médias & $\begin{array}{c}\text { Desvios } \\
\text { Padrão }\end{array}$ & Mínimos & Máximos \\
\hline $1997 / 1998$ & 16 & 12,78 & 8,02 & 5,98 & 32,31 \\
$1998 / 1999$ & 14 & 14,50 & 6,17 & 6,04 & 27,38 \\
$1999 / 2000$ & 13 & 17,58 & 11,91 & 9,18 & 50,86 \\
\hline
\end{tabular}


Tabela 27. Consumo de combustível ponderado por distância média (I.km.ha-1 $)$ referente às demais agroindústrias canavieiras amostradas que não participaram igualmente das três safras pesquisadas.

\begin{tabular}{cccccc}
\hline Safras & $\begin{array}{c}\text { Tamanhos } \\
\text { das Amostras }\end{array}$ & Médias & $\begin{array}{c}\text { Desvios } \\
\text { Padrão }\end{array}$ & Mínimos & Máximos \\
\hline $1997 / 1998$ & 51 & 13,66 & 11,70 & 3,05 & 57,06 \\
$1998 / 1999$ & 52 & 13,42 & 8,01 & 0,84 & 31,98 \\
$1999 / 2000$ & 42 & 17,78 & 16,33 & 2,19 & 74,58 \\
\hline
\end{tabular}

Quando são testadas as médias encontradas dentre as dezesseis empresas que participaram nas três pesquisas em comparação com as demais empresas em cada safra, têm-se os resultados da Tabela 28.

Tabela 28. Diferenças com intervalo de confiança de $95 \%$ entre as médias de consumo de combustível ponderado por distância média (I.km.ha-1) das amostras referentes somente às dezesseis agroindústrias canavieiras que participaram igualmente das três safras pesquisadas e das demais agroindústrias que não participaram igualmente das três safras.

\begin{tabular}{ccccc}
\hline Safras & $\begin{array}{c}\text { Médias das } \\
16 \text { empresas }\end{array}$ & $\begin{array}{c}\text { Médias das } \\
\text { demais } \\
\text { empresas }\end{array}$ & Diferenças & $\begin{array}{c}\text { Médias } \\
\text { Menores }\end{array}$ \\
\hline $1997 / 1998$ & 12,78 & 13,66 & $-6,04$ a 4,28 & indeterminável \\
$1998 / 1999$ & 14,50 & 13,42 & $-2,89$ a 5,05 & Indeterminável \\
$1999 / 2000$ & 17,58 & 17,78 & $-8,54$ a 8,14 & indeterminável \\
\hline
\end{tabular}


As diferenças das médias variando entre valores negativos e positivos tornam impossível determinar quais são as médias superiores nestes casos.

\subsubsection{Motores retificados no ano - MRA}

Este índice tanto pode sinalizar o estado de manutenção da frota, principalmente das manutenções básicas ou primárias (trocas de óleo do motor, trocas, limpezas e rodízios de filtros de ar) como também reflete o seu envelhecimento. Seus resultados encontram-se na Tabela 29.

Tabela 29. Motores retificados no ano (\%) ao longo de três safras contendo todas as agroindústrias canavieiras amostradas.

\begin{tabular}{cccccc}
\hline Safras & Amostras & Médias & Desvios Padrão & Mínimos & Máximos \\
\hline $1997 / 1998$ & 65 & 16,86 & 13,58 & 0 & 80,00 \\
$1998 / 1999$ & 73 & 11,64 & 8,49 & 0 & 41,86 \\
$1999 / 2000$ & 64 & 14,33 & 11,78 & 0 & 54,55 \\
\hline
\end{tabular}

Trata-se de mais um indicador com desvios padrões altos em comparação com as médias, fato este que se deve a ele englobar todos os tipos de motores, nas suas diferentes idades, formas de manutenção e situações de pós-retífica anterior.

Como o maior resultado mínimo para as três safras analisadas foi zero, este pode ser considerado como uma meta a ser buscada pelas empresas do 
setor, enquanto que a faixa definida acima do menor resultado máximo $(41,86 \mathrm{em}$ 1998/1999) pode ser assumida como a ocupada pelas piores empresas no tocante a este indicador.

Considerando-se um intervalo de confiança de 95\%, a Tabela 30 apresenta as estimativas para as populações totais de empresas nas três safras.

Tabela 30. Estimativas populacionais com intervalo de confiança de $95 \%$ para motores retificados no ano (\%) ao longo de três safras.

\begin{tabular}{cccc}
\hline Safras & $\begin{array}{c}\text { Tamanhos } \\
\text { das Amostras }\end{array}$ & $\begin{array}{c}\text { Erros Padrão } \\
\text { das Médias }\end{array}$ & $\begin{array}{c}\text { Valores Médios } \\
\text { das Populações }\end{array}$ \\
\hline $1997 / 1998$ & 67 & 1,51 & 13,90 a 19,82 \\
$1998 / 1999$ & 66 & 0,88 & 9,92 a 13,36 \\
$1999 / 2000$ & 55 & 1,32 & 11,74 a 16,92 \\
\hline
\end{tabular}

Pode-se, num primeiro momento, atentar para o curto prazo de um ano para se analisar a participação dos motores da frota que são retificados. Contudo, o acompanhamento rotineiro anual passa a ser um indicativo importante, já que os valores médios oscilaram aproximadamente entre 10 e $20 \%$ da frota e uma retífica de motor configura-se numa das mais dispendiosas manutenções de um equipamento motorizado.

A Tabela 31 apresenta os resultados das dezesseis empresas colaboradoras nas três safras, enquanto a Tabela 32 mostra os das demais empresas. 
Tabela 31. Motores retificados no ano (\%) ao longo de três safras referente somente às agroindústrias canavieiras amostradas que participaram igualmente das três safras pesquisadas.

\begin{tabular}{cccccc}
\hline \multirow{2}{*}{ Safras } & Amostras & Médias & Desvios Padrão & Mínimos & Máximos \\
& & & & & \\
\hline $1997 / 1998$ & 15 & 13,95 & 11,27 & 0 & 46,70 \\
$1998 / 1999$ & 16 & 15,98 & 9,65 & 0 & 41,86 \\
$1999 / 2000$ & 15 & 13,87 & 7,63 & 7,19 & 31,78 \\
\hline
\end{tabular}

Tabela 32. Motores retificados no ano (\%) ao longo de três safras referente às demais agroindústrias canavieiras amostradas que não participaram igualmente das três safras pesquisadas.

\begin{tabular}{cccccc}
\hline Safra & Amostras & Média & Desvio Padrão & Mínimo & Máximo \\
& & & & & \\
\hline $1997 / 1998$ & 50 & 17,54 & 13,58 & 1,26 & 80,00 \\
$1998 / 1999$ & 57 & 10,42 & 7,79 & 0 & 36,48 \\
$1999 / 2000$ & 49 & 14,48 & 12,84 & 0 & 54,55 \\
\hline
\end{tabular}

Quando são testadas as médias encontradas dentre as dezesseis empresas que participaram nas três pesquisas em comparação com as demais empresas em cada safra, têm-se os resultados da Tabela 33. 
Tabela 33. Diferenças com intervalo de confiança de 95\% entre as médias de motores retificados no ano (\%) das amostras referentes somente às dezesseis agroindústrias canavieiras que participaram igualmente das três safras pesquisadas e das demais agroindústrias que não participaram igualmente das três safras.

\begin{tabular}{ccccc}
\hline Safras & $\begin{array}{c}\text { Médias das } \\
16 \text { empresas }\end{array}$ & $\begin{array}{c}\text { Médias das } \\
\text { demais } \\
\text { empresas }\end{array}$ & Diferenças & Médias Menores \\
\hline $1997 / 1998$ & 13,95 & 17,54 & $-10,59$ a 3,41 & indeterminável \\
$1998 / 1999$ & 15,98 & 10,42 & 0,34 a 10,78 & demais empresas \\
$1999 / 2000$ & 13,87 & 14,48 & $-5,99$ a 4,77 & indeterminável \\
\hline
\end{tabular}

As diferenças das médias variando entre valores negativos e positivos tornam impossível determinar quais são as médias inferiores, a não ser na safra 1998/1999, que apontou o grupo das demais empresas que não foram assíduas como o de melhor resultado médio.

\subsection{Indicadores analítico-descritivos}

\subsubsection{Indicadores de idade}

\subsubsection{Idade média dos equipamentos automotrizes - IEA}


Os resultados da avaliação da idade média dos equipamentos automotrizes de todas as empresas amostradas nas três safras encontram-se na Tabela 34 .

Tabela 34. Idade média dos equipamentos automotrizes (anos) nas empresas amostradas nas três safras estudadas (1997/1998, 1998/1999 e 1999/2000).

\begin{tabular}{cccccc}
\hline Safras & Amostras & Médias & Desvios Padrão & Mínimos & Máximos \\
& & & & & \\
\hline $1997 / 1998$ & 64 & 9,17 & 2,39 & 3,14 & 17,67 \\
$1998 / 1999$ & 69 & 9,43 & 2,86 & 3,50 & 18,10 \\
$1999 / 2000$ & 61 & 10,49 & 2,77 & 3,55 & 16,22 \\
\hline
\end{tabular}

Mesmo sendo um indicador generalista, já que considera todos os equipamentos motorizados que se auto-locomovem das empresas (de automóveis a tratores de esteira, passando por caminhões, mas desconsiderando moto-bombas e motores estacionários), os desvios padrão mantiveram-se em patamares relativamente baixos em comparação com os indicadores anteriormente apresentados.

A faixa de resultados definida abaixo do maior resultado mínimo (3,55 para 1999/2000) pode ser considerada como uma meta a ser buscada pelas empresas do setor, enquanto que a faixa definida acima do menor resultado máximo $(16,22$ em 1999/2000) pode ser assumida como a ocupada pelas piores empresas no tocante a este indicador. 
Considerando-se um intervalo de confiança de 95\%, a Tabela 35 apresenta as estimativas para as populações totais de empresas nas três safras.

Tabela 35. Estimativas populacionais com intervalo de confiança de $95 \%$ para idade média dos equipamentos automotrizes (anos) ao longo de três safras.

\begin{tabular}{cccc}
\hline Safras & $\begin{array}{c}\text { Tamanhos } \\
\text { das Amostras }\end{array}$ & $\begin{array}{c}\text { Erros Padrão } \\
\text { das Médias }\end{array}$ & $\begin{array}{c}\text { Valores Médios } \\
\text { das Populações }\end{array}$ \\
\hline $1997 / 1998$ & 64 & 0,27 & 8,64 a 9,70 \\
$1998 / 1999$ & 69 & 0,31 & 8,82 a 10,04 \\
$1999 / 2000$ & 61 & 0,32 & 9,86 a 11,12 \\
\hline
\end{tabular}

Quando são testadas as médias encontradas nas amostragens das três safras da Tabela 34, safra a safra, têm-se os resultados da Tabela 36.

Tabela 36. Diferenças com intervalo de confiança de 95\% entre as médias de idade média dos equipamentos automotrizes (anos) das amostragens das três safras, safra a safra.

\begin{tabular}{ccc}
\hline Safras em teste & Diferenças & $\begin{array}{c}\text { Safras com Médias } \\
\text { Maiores }\end{array}$ \\
\hline $1998 / 1999$ e $1997 / 1998$ & $-0,63$ a 1,15 & indeterminável \\
$1999 / 2000$ e 1998/1999 & 0,09 a 2,03 & $1999 / 2000$ \\
$1999 / 2000$ e 1997/1998 & 0,41 a 2,23 & $1999 / 2000$ \\
\hline
\end{tabular}


A diferença das médias entre as safras 1999/2000 e 1997/1998 e entre as safras 1999/2000 e 1998/1999 sendo positivas em seus dois extremos confirma que a média de 1999/2000 é superior à de 1997/1998 e à de 1998/1999, enquanto que o outro teste não possibilitou identificar a média superior.

Desta forma, denota-se a tendência de envelhecimento das frotas automotrizes amostradas em 1999/2000, fato que pode ser explicado, conforme Pinazza et al. (2001), pelo setor sucroalcooleiro ter enfrentado, entre 1997 e 1999, um período de três anos de crise, sendo que 1999 foi o pior momento, com fracas cotações de açúcar e álcool.

\subsubsection{Idade média dos veículos - IVE}

As apurações de idades médias dos veículos de todas as empresas amostradas nas três safras encontram-se na Tabela 37.

Tabela 37. Idade média dos veículos (anos) nas empresas amostradas nas três safras estudadas (1997/1998, 1998/1999 e 1999/2000).

\begin{tabular}{cccccc}
\hline \multirow{2}{*}{ Safras } & Amostras & Médias & Desvios Padrão & Mínimos & Máximos \\
& & & & & \\
\hline $1997 / 1998$ & 64 & 9,23 & 2,67 & 2,62 & 16,96 \\
$1998 / 1999$ & 70 & 9,79 & 3,30 & 3,80 & 18,70 \\
$1999 / 2000$ & 67 & 10,47 & 3,32 & 3,68 & 19,67 \\
\hline
\end{tabular}


Como em IEA, porém menos generalista, o IVE teve seus desvios padrão mantidos em patamares relativamente baixos, ao contrário da maioria dos indicadores anteriormente apresentados.

A faixa de resultados definida abaixo do maior resultado mínimo (3,80 para 1998/1999) pode ser considerada como uma meta a ser buscada pelas empresas do setor, enquanto que a faixa definida acima do menor resultado máximo $(16,96$ em 1997/1998) pode ser assumida como a ocupada pelas piores empresas no tocante a este indicador.

Considerando-se um intervalo de confiança de 95\%, a Tabela 38 apresenta as estimativas para as populações totais de empresas nas três safras.

Tabela 38. Estimativas populacionais com intervalo de confiança de $95 \%$ para idade média dos veículos (anos) ao longo de três safras.

\begin{tabular}{cccc}
\hline Safras & $\begin{array}{c}\text { Tamanhos } \\
\text { das Amostras }\end{array}$ & $\begin{array}{c}\text { Erros Padrão } \\
\text { das Médias }\end{array}$ & $\begin{array}{c}\text { Valores Médios } \\
\text { das Populações }\end{array}$ \\
\hline $1997 / 1998$ & 64 & 0,30 & 8,64 a 9,82 \\
$1998 / 1999$ & 70 & 0,35 & 9,10 a 10,48 \\
$1999 / 2000$ & 67 & 0,36 & 9,76 a 11,18 \\
\hline
\end{tabular}

A idade média dos veículos das agroindústrias canavieiras, mesmo sendo relativamente avançada, já que se encontra entre 8,64 e 11,18 anos, ainda é menor do que a idade média da frota brasileira de caminhões, conforme cita Transporte Moderno (1997), com a idade de 13,85 anos. 
Quando são testadas as médias encontradas nas amostragens das três safras da Tabela 37, safra a safra, têm-se os resultados da Tabela 39.

Tabela 39. Diferenças com intervalo de confiança de 95\% entre as médias de idade média dos veículos (anos) das amostragens das três safras, safra a safra.

\begin{tabular}{ccc}
\hline Safras em teste & Diferenças & $\begin{array}{c}\text { Safras com Médias } \\
\text { Maiores }\end{array}$ \\
\hline $1998 / 1999$ e $1997 / 1998$ & $-0,45$ a 1,57 & indeterminável \\
$1999 / 2000$ e 1998/1999 & $-0,43$ a 1,79 & Indeterminável \\
$1999 / 2000$ e 1997/1998 & 0,21 a 2,27 & $1999 / 2000$ \\
\hline
\end{tabular}

Os testes possibilitaram somente identificar que a idade média dos veículos em 1999/2000 é superior a dos veículos de 1997/1998, já que as outras duas diferenças se encontram entre valores positivos e negativos. Este envelhecimento dos veículos em 1999/2000 explica parcialmente os resultados do IEA, já que o IEA engloba também os veículos das agroindústrias canavieiras

\subsubsection{Idade média das máquinas - IMA}

Finalizando os indicadores de idade, a Tabela 40 apresenta os resultados de idade média das máquinas de todas as empresas amostradas nas três safras. 
Tabela 40. Idade média das máquinas (anos) nas empresas amostradas nas três safras estudadas (1997/1998, 1998/1999 e 1999/2000).

\begin{tabular}{cccccc}
\hline \multirow{2}{*}{ Safras } & Amostras & Médias & Desvios Padrão & Mínimos & Máximos \\
& & & & & \\
\hline $1997 / 1998$ & 64 & 9,06 & 2,89 & 3,55 & 20,59 \\
$1998 / 1999$ & 69 & 9,22 & 3,43 & 3,20 & 19,70 \\
$1999 / 2000$ & 62 & 10,36 & 3,02 & 3,40 & 17,19 \\
\hline
\end{tabular}

Como em IVE, o IMA teve seus desvios padrões mantidos em patamares relativamente baixos, ao contrário da maioria dos indicadores anteriormente apresentados.

A faixa de resultados definida abaixo do maior resultado mínimo (3,55 para 1997/1998) pode ser considerada como uma meta a ser buscada pelas empresas do setor, enquanto que a faixa definida acima do menor resultado máximo $(17,19$ em 1999/2000) pode ser assumida como a ocupada pelas piores empresas no tocante a este indicador.

Considerando-se um intervalo de confiança de 95\%, a Tabela 41 apresenta as estimativas para as populações totais de empresas nas três safras. 
Tabela 41. Estimativas populacionais com intervalo de confiança de $95 \%$ para idade média das máquinas (anos) ao longo de três safras.

\begin{tabular}{cccc}
\hline Safras & $\begin{array}{c}\text { Tamanhos } \\
\text { das Amostras }\end{array}$ & $\begin{array}{c}\text { Erros Padrão } \\
\text { das Médias }\end{array}$ & $\begin{array}{c}\text { Valores Médios } \\
\text { das Populações }\end{array}$ \\
\hline $1997 / 1998$ & 64 & 0,32 & 8,43 a 9,69 \\
$1998 / 1999$ & 69 & 0,35 & 8,49 a 9,95 \\
$1999 / 2000$ & 62 & 0,36 & 9,67 a 11,05 \\
\hline
\end{tabular}

A idade média das máquinas das agroindústrias canavieiras, que encontrase entre 8,43 e 11,05 anos, está relativamente avançada, comparando-se, por exemplo, com o estudo de Klinger \& Mattos (1987), que apontou que tratores de 108 CV na região de Marília (SP) tinham a durabilidade média de 7 anos.

Já Silva \& Kageyama ${ }^{3}$, citados por Moreira \& Menezes (1973), afirmaram que a vida média esperada de máquinas agrícolas que trabalhem acima de 1.800 horas por ano é de 4 a 5 anos.

Quando são testadas as médias encontradas nas amostragens das três safras da Tabela 40, safra a safra, têm-se os resultados da Tabela 42.

${ }^{3}$ SILVA, J. F. G.; KAGEYAMA, A. A. O preço de produção na agricultura: uma introdução à economia rural. Campinas, Instituto de Filosofia e Ciências Humanas, UNICAMP, 1979. Texto não publicado 
Tabela 42. Diferenças com intervalo de confiança de 95\% entre as médias de idade média das máquinas (anos) das amostragens das três safras, safra a safra.

\begin{tabular}{ccc}
\hline Safras em teste & Diferenças & $\begin{array}{c}\text { Safras com Médias } \\
\text { Maiores }\end{array}$ \\
\hline $1998 / 1999$ e 1997/1998 & $-0,92$ a 1,24 & indeterminável \\
$1999 / 2000$ e 1998/1999 & 0,04 a 2,24 & $1999 / 2000$ \\
$1999 / 2000$ e 1997/1998 & 0,27 a 2,33 & $1999 / 2000$ \\
\hline
\end{tabular}

A diferença das médias entre as safras 1999/2000 e 1997/1998 e entre as safras 1999/2000 e 1998/1999 sendo positivas em seus dois extremos confirma que a média de 1999/2000 é superior à de 1997/1998 e à de 1998/1999, enquanto que o outro teste não possibilitou identificar a média superior.

Desta forma, o IMA, respondendo por parte dos equipamentos automotrizes contidos no IEA, confirma-o e mostra ser o maior responsável pelo comportamento do IEA, apresentando o mesmo resultado do teste das médias entre as safras.

\subsubsection{Indicadores de estratégia}

Diferentemente dos indicadores anteriores, os indicadores de estratégia não são necessariamente empregados para avaliar o desempenho da frota, mas servem para conhecer as opções e alternativas que os administradores das frotas canavieiras estão adotando. 


\subsubsection{Terceirização dos equipamentos motorizados - TMT}

Os resultados deste indicador nas empresas amostradas estão na Tabela 43.

Tabela 43. Terceirização (\%) dos equipamentos motorizados nas empresas amostradas entre 1997/1998 e 1999/2000.

\begin{tabular}{cccccc}
\hline \multirow{2}{*}{ Safras } & Amostras & Médias & Desvios Padrão & Mínimos & Máximos \\
& & & & & \\
\hline $1997 / 1998$ & 66 & 13,78 & 17,02 & 0 & 81,60 \\
$1998 / 1999$ & 73 & 15,82 & 17,52 & 0 & 71,20 \\
$1999 / 2000$ & 70 & 21,36 & 23,88 & 0 & 100,00 \\
\hline
\end{tabular}

Este indicador apresenta desvios padrão maiores do que as médias, em parte explicados pela grande amplitude entre mínimos e máximos, como na safra 1999/2000, que alcançou 100\%. Ainda está longe de se estabelecer um consenso no tocante à participação ideal da terceirização de frotas nas agroindústrias canavieiras.

Considerando-se um intervalo de confiança de 95\%, a Tabela 44 apresenta as estimativas para as populações totais de empresas nas três safras. 
Tabela 44. Estimativas populacionais com intervalo de confiança de $95 \%$ para a terceirização (\%) dos equipamentos motorizados ao longo de três safras.

\begin{tabular}{cccc}
\hline Safras & $\begin{array}{c}\text { Tamanhos das } \\
\text { Amostras }\end{array}$ & $\begin{array}{c}\text { Erros Padrão } \\
\text { das Médias }\end{array}$ & $\begin{array}{c}\text { Valores Médios } \\
\text { das Populações }\end{array}$ \\
\hline $1997 / 1998$ & 66 & 1,87 & 10,11 a 17,45 \\
$1998 / 1999$ & 73 & 1,81 & 12,27 a 19,37 \\
$1999 / 2000$ & 70 & 2,53 & 16,40 a 26,32 \\
\hline
\end{tabular}

Quando são testadas as médias encontradas nas amostragens das três safras da Tabela 43, safra a safra, têm-se os resultados da Tabela 45.

Tabela 45. Diferenças com intervalo de confiança de 95\% entre as médias de terceirização (\%) dos equipamentos motorizados das amostragens das três safras, safra a safra.

\begin{tabular}{ccc}
\hline Safras em teste & Diferenças & $\begin{array}{c}\text { Safras com Médias } \\
\text { Maiores }\end{array}$ \\
\hline $1998 / 1999$ e $1997 / 1998$ & $-3,71$ a 7,79 & indeterminável \\
$1999 / 2000$ e 1998/1999 & $-1,35$ a 12,43 & Indeterminável \\
$1999 / 2000$ e 1997/1998 & 0,64 a 14,52 & $1999 / 2000$ \\
\hline
\end{tabular}

Os testes possibilitaram somente identificar que a média de terceirização dos equipamentos motorizados foi superior em 1999/2000 do que em 1997/1998, já que as outras duas diferenças se encontram entre valores positivos e 
negativos. Este crescimento da terceirização em 1999/2000 se opõe ao envelhecimento dos equipamentos motorizados, configurando-se como outra alternativa que as agroindústrias canavieiras adotaram para enfrentar a crise de preços de seus produtos por que passaram no período estudado.

\subsubsection{Plantio mecanizado de cana - PMN}

Os valores encontrados para PMN encontram-se na Tabela 46.

Tabela 46. Plantio mecanizado de cana (\%) nas empresas amostradas entre 1997/1998 e 1999/2000.

\begin{tabular}{cccccc}
\hline Safras & Amostras & Médias & Desvios Padrão & Mínimos & Máximos \\
& & & & & \\
\hline $1997 / 1998$ & 67 & 1,39 & 8,11 & 0 & 52,25 \\
$1998 / 1999$ & 72 & 10,70 & 27,99 & 0 & 100,00 \\
$1999 / 2000$ & 69 & 16,78 & 31,65 & 0 & 100,00 \\
\hline
\end{tabular}

Este indicador apresenta desvios padrões significativamente superiores do que as médias, também em parte explicados pela grande amplitude entre mínimos e máximos, como nas safras 1998/1999 e 1999/2000, que alcançaram $100 \%$.

Considerando-se um intervalo de confiança de 95\%, a Tabela 47 apresenta as estimativas para as populações totais de empresas nas três safras. 
Tabela 47. Estimativas populacionais com intervalo de confiança de $95 \%$ para o plantio mecanizado de cana (\%) ao longo de três safras.

\begin{tabular}{cccc}
\hline Safras & $\begin{array}{c}\text { Tamanhos } \\
\text { das Amostras }\end{array}$ & $\begin{array}{c}\text { Erros Padrão } \\
\text { das Médias }\end{array}$ & $\begin{array}{c}\text { Valores Médios } \\
\text { das Populações }\end{array}$ \\
\hline $1997 / 1998$ & 67 & 1,88 & 0,00 a 5,07 \\
$1998 / 1999$ & 72 & 2,91 & 5,00 a 16,40 \\
$1999 / 2000$ & 69 & 3,38 & 10,16 a 23,40 \\
\hline
\end{tabular}

O plantio mecanizado de cana configura-se em mais uma atividade que, até há pouco tempo, era quase que completamente manual, como indica o intervalo entre 0 e 5,07\% das áreas das empresas com plantio mecanizado, e que vem se tornando mecanizada, como mostram os testes das médias encontradas nas amostragens das três safras da Tabela 46, safra a safra, e que têm os resultados apresentados na Tabela 48.

Tabela 48. Diferenças com intervalo de confiança de 95\% entre as médias de plantio mecanizado de cana (\%) das amostragens das três safras, safra a safra.

\begin{tabular}{ccc}
\hline Safras em teste & Diferenças & $\begin{array}{c}\text { Safras com Médias } \\
\text { Maiores }\end{array}$ \\
\hline $1998 / 1999$ e 1997/1998 & 2,56 a 16,06 & $1998 / 1999$ \\
$1999 / 2000$ e 1998/1999 & $-3,80$ a 15,96 & Indeterminável \\
$1999 / 2000$ e 1997/1998 & 7,67 a 23,11 & $1999 / 2000$ \\
\hline
\end{tabular}


Os testes possibilitaram identificar que as médias das safras 1998/1999 e 1999/2000 são superiores a de 1997/1998, ou seja, definindo que houve uma expansão do plantio mecanizado de cana nas empresas entre 1997/1998 e as duas safras seguintes, provavelmente pela evolução da viabilidade tecnológicoeconômica desta prática. A mecanização crescente do plantio vai eliminando mais uma atividade manual que abrigava diversos postos de trabalho para rurícolas no setor sucroalcooleiro nacional.

\subsubsection{Colheita mecanizada de cana - CMC}

Seus resultados apurados encontram-se na Tabela 49:

Tabela 49. Colheita mecanizada de cana (\%) nas unidades produtoras amostradas entre 1997/1998 e 1999/2000.

\begin{tabular}{cccccc}
\hline \multirow{2}{*}{ Safras } & Amostras & Médias & Desvios Padrão & Mínimos & Máximos \\
& & & & & \\
\hline $1997 / 1998$ & 67 & 8,52 & 15,06 & 0 & 52,00 \\
$1998 / 1999$ & 63 & 13,77 & 19,59 & 0 & 71,26 \\
$1999 / 2000$ & 64 & 16,41 & 21,68 & 0 & 78,93 \\
\hline
\end{tabular}

Como ocorreu nos demais indicadores de estratégia, este também apresenta desvios padrão superiores às médias, explicados parcialmente pela grande amplitude entre mínimos e máximos, como na safra 1999/2000, que alcançou $78,93 \%$. 
Considerando-se um intervalo de confiança de 95\%, a Tabela 50 apresenta as estimativas para as populações totais de empresas nas três safras.

Tabela 50. Estimativas populacionais com intervalo de confiança de $95 \%$ para colheita mecanizada de cana (\%) ao longo de três safras.

\begin{tabular}{cccc}
\hline Safras & $\begin{array}{c}\text { Tamanhos } \\
\text { das Amostras }\end{array}$ & $\begin{array}{c}\text { Erros Padrão } \\
\text { das Médias }\end{array}$ & $\begin{array}{c}\text { Valores Médios } \\
\text { das Populações }\end{array}$ \\
\hline $1997 / 1998$ & 67 & 1,64 & 5,31 a 11,73 \\
$1998 / 1999$ & 63 & 2,22 & 9,42 a 18,12 \\
$1999 / 2000$ & 64 & 2,43 & 11,65 a 21,17 \\
\hline
\end{tabular}

Quando são testadas as médias encontradas nas amostragens das três safras da Tabela 49, safra a safra, têm-se os resultados da Tabela 51.

Tabela 51. Diferenças com intervalo de confiança de 95\% entre as médias de colheita mecanizada de cana (\%) das amostragens das três safras, safra a safra.

\begin{tabular}{ccc}
\hline Safras em teste & Diferenças & $\begin{array}{c}\text { Safras com Médias } \\
\text { Maiores }\end{array}$ \\
\hline $1998 / 1999$ e 1997/1998 & $-0,78$ a 11,28 & Indeterminável \\
$1999 / 2000$ e 1998/1999 & $-4,54$ a 9,82 & Indeterminável \\
$1999 / 2000$ e 1997/1998 & 1,47 a 14,31 & $1999 / 2000$ \\
\hline
\end{tabular}


Houve crescimento das áreas com colheita mecanizada de cana nas agroindústrias em 1999/2000 em comparação com 1997/1998. Trata-se da atividade do processo de produção de cana-de-açúcar que mais demanda mãode-obra braçal e que, como o plantio mecanizado, expande-se nas agroindústrias canavieiras, atingindo entre 11,65 e $21,17 \%$ das suas áreas de colheita em 1999/2000, diminuindo postos de trabalho e, conforme Romanach \& Caron (1999), também seus custos, já que os autores citam em seu estudo de caso que o custo da colheita mecanizada foi $55,44 \%$ menor do que a manual.

\subsection{Resultados das empresas assíduas}

Dentre os seis indicadores de avaliação de desempenho das frotas cujos resultados médios das empresas que participaram assiduamente das três safras de estudo foram comparados com os das empresas que não participaram assiduamente nas três safras, num total de dezoito comparações (três por indicador), em duas comparações (do indicador CCD) o grupo das empresas assíduas apresentou melhor resultado médio, enquanto que, em uma comparação (do indicador MRA), este foi pior e, nas demais quinze comparações não se pode definir superioridade dentre as comparações. 


\section{CONCLUSÕES}

Os resultados obtidos e as discussões realizadas permitiram concluir o que se segue.

Os treze indicadores propostos de avaliação de desempenho e analíticodescritivos mostraram-se válidos para serem adotados pelas agroindústrias canavieiras como referenciais de comparação (por meio dos intervalos médios de resultados) e de metas de excelência (por meio das faixas acima dos valores máximos), configurando-se em ferramentas de auxílio ao gerenciamento de suas frotas e como forma de representação das características que dizem respeito.

Houve tênue superioridade entre os resultados médios das empresas que participaram assiduamente das três safras do estudo junto aos indicadores de avaliação operacional se comparados com os das empresas que não participaram assiduamente nas três safras, fato este que, aliado aos desvios padrão relativamente altos e às significativas amplitudes entre os valores mínimos e máximos das amostras, sugerem que o acompanhamento rotineiro dos indicadores pode influir na melhoria dos resultados das frotas das agroindústrias canavieiras e há espaço nas empresas para tais melhorias. 
A frota de equipamentos automotrizes das agroindústrias canavieiras envelheceu entre 1997/1998 e 1999/2000, tanto na sua componente de veículos como, principalmente, na sua componente de máquinas.

A terceirização dos equipamentos automotrizes nas agroindústrias canavieiras cresceu entre 1997/1998 e 1999/2000.

O plantio mecanizado nas áreas das agroindústrias canavieiras cresceu entre 1997/1998 e 1999/2000, bem como a parcela das áreas de colheita de cana-de-açúcar colhida mecanicamente. 
ANEXOS 
Anexo A Relação de agroindústrias canavieiras que responderam aos questionários sobre a safra 1997/1998, enviados em Março de 1998 (em azul estão as que participaram nas três safras estudadas):

\section{Agroindústrias}

Estados

Benálcool Açúcar e Álcool S/A

SP

Companhia Açucareira de Penápolis - Usina Campestre

SP

Clealco Açúcar e Álcool S/A

SP

Diana Destilaria de Álcool Nova Avanhandava Ltda.

SP

Equipav S/A Açúcar e Álcool

SP

Destilaria Pioneiros S/A

SP

Univalem S/A Açúcar e Álcool

SP

Destilaria Água Bonita Ltda.

SP

Cocal Com. Ind. Canaã Álcool e Açúcar Ltda.

SP

Ipaussu Indústria e Comércio Ltda.

SP

Companhia Agrícola Nova América

SP

Companhia Agrícola Santa Amélia

SP

Usina Da Barra S/A Açúcar e Álcool

SP

Destilaria Della Coletta Ltda.

SP

Destilaria Paraíso

SP

Santa Cândida Açúcar e Álcool Ltda.

SP

Usina Costa Pinto S/A Açúcar e Álcool

SP

Dedini Açúcar e Álcool Ltda.

SP

Dedini S/A Agro-Indústria

SP

Usina Açucareira Ester S/A

SP 
Anexo A Relação de agroindústrias canavieiras que responderam aos questionários sobre a safra 1997/1998, enviados em Março de 1998 (em azul estão as que participaram nas três safras estudadas):

Agroindústrias Estados

Indústria Açucareira São Francisco S/A SP

Usina Santa Helena S/A Açúcar e Álcool SP

Agropecuária Nossa Senhora do Carmo SP

Agro Industrial Vista Alegre Ltda. $\quad$ SP

Companhia Albertina Mercantil e Industrial SP

Usina Alta Mogiana S/A Açúcar e Álcool SP

Companhia Agrícola Colombo SP

Açucareira Corona S/A SP

Fundação Sinhá Junqueira $\quad$ SP

Usina Mandu S/A SP

Usina Nardini S/A SP

Usina Açucareira Santa Luiza $\quad$ SP

Nova Aliança Ltda. - Usina Vale do Rosário SP

Destilaria Virálcool Ltda. $\quad$ SP

Usina Cerradinho Açúcar e Álcool S/A SP

Açúcar Guarani S/A SP

Usina Moema Açúcar e Álcool Ltda. $\quad$ SP

Usina São José da Estiva $\quad$ SP

Virgolino de Oliveira S/A - unidade Catanduva SP

Destilaria Vale do Rio Turvo SP 
Anexo A Relação de agroindústrias canavieiras que responderam aos questionários sobre a safra 1997/1998, enviados em Março de 1998 (em azul estão as que participaram nas três safras estudadas):

Agroindústrias Estados

Anicuns S/A Álcool e Derivados

GO

Jalles Machado S/A Açúcar e Álcool

GO

Usina Alvorada Ltda. Açúcar e Álcool MG

Usina Delta S/A Açúcar e Álcool MG

Companhia Agrícola Pontenovense MG

Usina Maracaju S/A $\quad$ MS

Agro Industrial Passa Tempo S/A MS

Rio Corrente Agrícola S/A MS

Usina Alto Alegre S/A Açúcar e Álcool $\quad$ PR

Cocamar - Cooperativa de cafeicultores e Agropec. de Maringá Ltda. PR

Destilaria Cocari - Cooperativa dos cafeicultores de Mandaguari Ltda. $\quad$ PR

Destilaria Copagra - Cooperativa Agrícola dos Cafeic. de Nova Londrina PR

Companhia Melhoramentos Norte do Paraná PR

Wilson Baggio e Filhos $\quad$ PR

Caeté S/A - filial Cachoeira $\quad$ AL

S/A Usina Coruripe Açúcar e Álcool $\quad$ AL

Usina Laginha Agro-industrial S/A - matriz $\quad$ AL

Laginha Agro-industrial S/A - filial Uruba $\quad A L$

Usina Serra Grande S/A $\quad$ AL

Gramame Industrial e Agrícola S/A PB 
Anexo A Relação de agroindústrias canavieiras que responderam aos questionários sobre a safra 1997/1998, enviados em Março de 1998 (em azul estão as que participaram nas três safras estudadas):

Agroindústrias

Estados

Japungu Agroindustrial S/A

PB

Usina Monte Alegre S/A

PE

Usina Central Olho D'Água

PE

Usina Estivas S/A

RN

Usina Sapucaia S/A

RJ

Usina Santa Cruz S/A

RJ

Usina Paineiras S/A

ES 
Anexo B Relação de agroindústrias canavieiras que responderam aos questionários sobre a safra 1998/1999, enviados em Março de 1999 (em azul estão as que participaram nas três safras estudadas):

Agroindústrias

Estados

Araçatuba Álcool S/A

Companhia Açucareira de Penápolis - Usina Campestre

SP

Destilaria Alcídia S/A

SP

Usina Alta Floresta S/A Açúcar e Álcool

SP

Equipav S/A Açúcar e Álcool

SP

Destilaria Pioneiros S/A

SP

Destilaria de Álcool Califórnia Ltda.

SP

Central Paulista Açúcar e Álcool Ltda.

SP

Cocal Com. Ind. Canaã Álcool e Açúcar Ltda.

SP

Indústria Açucareira São Francisco S/A - filial Ipaussu

SP

Companhia Agrícola Nova América

SP

Companhia Agrícola Santa Amélia

SP

Irmãos Franceschi S/A - Usina Diamante

SP

Destilaria Della Coletta Ltda.

SP

Usina Açucareira São Manoel S/A

SP

Santa Cândida Açúcar e Álcool Ltda.

SP

Usina Da Barra S/A Açúcar e Álcool

SP

Usina Costa Pinto S/A Açúcar e Álcool

SP

Dedini S/A Agro-Indústria - São João

SP 
Anexo B Relação de agroindústrias canavieiras que responderam aos questionários sobre a safra 1998/1999, enviados em Março de 1999 (em azul estão as que participaram nas três safras estudadas):

Agroindústrias

Estados

Dedini S/A Agro-Indústria - São Luiz

Usina Açucareira Ester S/A

SP

Indústria Açucareira São Francisco S/A

$\mathrm{SP}$

Usina Santa Helena S/A Açúcar e Álcool

SP

Companhia Industrial e Agrícola São João

SP

Agro Industrial Vista Alegre Ltda.

SP

Companhia Albertina Mercantil e Industrial

SP

Usina Alta Mogiana S/A Açúcar e Álcool

SP

Companhia Agrícola Colombo

SP

Usina Açucareira Bela Vista S/A

SP

Fundação Sinhá Junqueira

SP

Usina Mandu S/A

SP

Central Energética Moreno Açúcar e Álcool Ltda.

SP

Destilaria Andrade

SP

Nova Aliança Ltda. - Usina Vale do Rosário

SP

Destilaria Pitangueiras Ltda.

SP

Agropecuária Santa Catarina S/A

SP

Nova União S/A Açúcar e Álcool

SP

Usina São Domingos Açúcar e Álcool S/A

SP 
Anexo B Relação de agroindústrias canavieiras que responderam aos questionários sobre a safra 1998/1999, enviados em Março de 1999 (em azul estão as que participaram nas três safras estudadas):

Agroindústrias

Estados

Açúcar Guarani S/A SP

Usina São José da Estiva SP

Virgolino de Oliveira S/A - unidade Catanduva

SP

Usina Santa Helena de Açúcar e Álcool S/A

GO

Goiatuba Álcool Ltda.

GO

Jalles Machado S/A Açúcar e Álcool

GO

Usina Alvorada Ltda. Açúcar e Álcool

MG

Usina Delta S/A Açúcar e Álcool

MG

Iturama Agro-industrial Ltda.

MG

Destilaria Serra dos Aimorés S/A

MG

Usina Monte Alegre Ltda.

MG

Usina Caeté S/A - filial Volta Grande

MG

Usina Maracaju S/A

MS

Agro Industrial Santa Helena Ltda.

MS

Rio Corrente Agrícola S/A

MS

Usina Jaciara S/A

MT

Usinas Itamarati S/A

MT

Usina Alto Alegre S/A Açúcar e Álcool

PR

Cocamar - Cooperativa de cafeicultores e Agropec. de Maringá Ltda.

PR 
Anexo B Relação de agroindústrias canavieiras que responderam aos questionários sobre a safra 1998/1999, enviados em Março de 1999 (em azul estão as que participaram nas três safras estudadas):

Agroindústrias

Estados

Cooperativa Agrícola de Cafeicultores de Porecatu Ltda.

PR

Cooperativa Agrícola da Região Produtora de Cana Ltda. - Coopcana

PR

Vale do Ivaí Açúcar e Álcool Ltda.

PR

Sabarálcool S/A Açúcar e Álcool

PR

Triunfo Agro-industrial S/A

AL

Laginha Agro-industrial S/A - filial Guaxuma

AL

Agro-indústrias do Vale do São Francisco S/A

BA

Gramame Industrial e Agrícola S/A

PB

Companhia Industrial do Nordeste Brasileiro

PE

Companhia Geral de Melhoramentos em Pernambuco

PE

Usina Salgado S/A

PE

Usina Estivas S/A

RN

Usina São José S/A

RJ

Usina Santa Cruz S/A

RJ

Destilaria Itaúnas S/A Açúcar e Álcool

ES

Cristal Destilaria Autônoma de Álcool S/A

ES 
Anexo C Relação de agroindústrias canavieiras que responderam aos questionários sobre a safra 1999/2000, enviados em Março de 2000 (em azul estão as que participaram nas três safras estudadas):

Agroindústrias

Estados

Benálcool Açúcar e Álcool S/A

Companhia Açucareira de Penápolis - Usina Campestre

SP

Clealco S/A

SP

Destilaria de Álcool Califórnia Ltda.

SP

Guanabara Agro-industrial S/A

SP

Destilaria Pioneiros S/A

SP

Unialco S/A Açúcar e Álcool

SP

Sobar Álcool e Derivados Ltda.

SP

Central Paulista Açúcar e Álcool Ltda.

SP

Usina Açucareira Ester S/A

SP

Companhia Industria e Agrícola Ometto

SP

Companhia Agrícola Santa Amélia

SP

Indústrias de Bebidas Müller Ltda.

SP

Usina São João Açúcar e Álcool S/A

SP

Agro Industrial Vista Alegre Ltda.

SP

Santa Cândida Açúcar e Álcool Ltda.

SP

Destilaria Andrade S/A

SP

Fundação Sinhá Junqueira

SP

Dedini S/A Agro-Indústria - São João

SP 
Anexo C Relação de agroindústrias canavieiras que responderam aos questionários sobre a safra 1999/2000, enviados em Março de 2000 (em azul estão as que participaram nas três safras estudadas):

Agroindústrias

Estados

Dedini S/A Agro-Indústria - São Luiz

Usina Mandu S/A

SP

Usina Maringá S/A Indústria e Comércio

SP

Central Energética Moreno Açúcar e Álcool Ltda.

SP

Usina Santa Rita S/A Açúcar e Álcool

SP

Usina Zanin Açúcar e Álcool Ltda.

SP

Companhia Albertina Mercantil e Industrial

SP

Usina Alta Mogiana S/A Açúcar e Álcool

SP

Destilaria Itajobi S/A

SP

Usina Moema Açúcar e Álcool Ltda.

SP

Usina São Domingos Açúcar e Álcool S/A

SP

Açúcar Guarani S/A

SP

Usina São José da Estiva

SP

Virgolino de Oliveira S/A - unidade Catanduva

SP

Usina Santa Helena de Açúcar e Álcool S/A

GO

Centroálcool S/A

GO

Destilaria Vale do Palmas S/A

TO

Usina Alvorada Ltda. Açúcar e Álcool

MG

Usina Delta S/A Açúcar e Álcool

MG 
Anexo C Relação de agroindústrias canavieiras que responderam aos questionários sobre a safra 1999/2000, enviados em Março de 2000 (em azul estão as que participaram nas três safras estudadas):

Agroindústrias

Estados

S/A Usina Coruripe Açúcar e Álcool - unidade Iturama MG

Destilaria Alvorada do Bebedouro Ltda.

MG

Usina Monte Alegre Ltda.

MG

Companhia Industrial e Agrícola Oeste de Minas

MG

Usina Santo Ângelo Ltda.

MG

Usina Caeté S/A - filial Volta Grande

MG

Usina Maracaju S/A

MS

Usina Brasilândia Açúcar e Álcool Ltda.

MS

Agro Industrial Passa Tempo S/A

MS

Agro Industrial Santa Helena Ltda.

MS

Rio Corrente Agrícola S/A

MS

Usina Jaciara S/A

MT

Usina Pantanal de Açúcar e Álcool Ltda.

MT

Usinas Itamarati S/A

MT

Usina Alto Alegre S/A Açúcar e Álcool

PR

Cooperativa Agrícola de Cafeicultores de Porecatu Ltda.

PR

Vale do Ivaí Açúcar e Álcool Ltda.

PR

Cooperativa Agropecuária de Rolândia Ltda.

PR

Destilaria Americana S/A

PR 
Anexo C Relação de agroindústrias canavieiras que responderam aos questionários sobre a safra 1999/2000, enviados em Março de 2000 (em azul estão as que participaram nas três safras estudadas):

\section{Agroindústrias}

Estados

Destilaria Melhoramentos S/A PR

Usina Caeté S/A AL

Laginha Agro-industrial S/A - filial Uruba AL

Laginha Agro-industrial S/A - filial Guaxuma

AL

Cooperativa de Colonização Agropecuária Industrial Pindorama Ltda.

$\mathrm{AL}$

Usina Serra Grande S/A

$\mathrm{AL}$

Nova Aliança S/A

BA

Companhia Industrial do Nordeste Brasileiro

PE

Companhia Geral de Melhoramentos em Pernambuco

PE

Usina Salgado S/A

PE

Usina Estivas S/A

RN

Usina São José S/A

RJ

Usina Carapebus S/A

RJ

Companhia Açucareira Usina Cupim

RJ

Destilaria Itaúnas S/A Açúcar e Álcool

ES

Cristal Destilaria Autônoma de Álcool S/A

ES 


\section{REFERÊNCIAS BIBLIOGRÁFICAS}

ANUÁRIO CENTRO-SUL Anuário Jornalcana - Centro-Sul - Safra 1997/1998.

Ribeirão Preto: Apoio \& Vendas, 1998. 255p.

ANUÁRIO NORTE/NORDESTE Anuário Jornalcana - Norte/Nordeste - Safra

1997/1998. Ribeirão Preto: Apoio \& Vendas, 1998. 138p.

BANCHI, A. D.; MACHADO, M. C. Controle computacional de frota. In: SEMINÁRIO DE TECNOLOGIA AGRONÔMICA, 4., Piracicaba, 1988. Anais. Piracicaba: COPERSUCAR, 1988. p431-492.

CASTELLO BRANCO, J. E. S. Indicadores da Qualidade e Desempenho de Ferrovias (Carga e Passageiro). Rio de Janeiro: Associação Nacional dos Transportadores Ferroviários - ANTF, 1998. 128p.

FILGUEIRAS, J. F. Um modelo de substituição de equipamentos para minimizar custos operacionais em uma empresa florestal. Viçosa, 1997. 54p. Dissertação (Mestrado) - Universidade Federal de Viçosa.

FPNQ* Critérios de excelência - o estado da arte da gestão da qualidade total. São Paulo: FNPQ, 1995. 37p. 
FRANCISCHINI, P. G. Indicadores de produtividade. AOTS/SP Magazine, v.1, n.1, p. 22-24, abr./maio 1998.

GREEN, P. E.; TULL, D. S.; ALBAUM, G. Research for marketing decisions, 5. ed. New Delhi: Prentice Hall of India, 1993. 796p.

KAZMIER, L. J. Estatística aplicada à economia e administração. Trad. de C. A. Crusius. São Paulo: McGraw-Hill do Brasil, 1982. 376p.

KLINGER, M.; MATTOS, Z. P. B. Custo-hora de tratores: um estudo preliminar. Economia rural, v.2, n.25, p.75-89, abr./jun. 1987.

KORNHAUSER, A.; SHEATSLEY, P. B. Questionnaire construction and interview procedure. In: SELLTIZ, C.; WRIGHTSMAN, L. S.; COOK, S. W. Research Methods in Social Relations. 3. ed. New York: Holt, Rinehart and Winston, 1976. cap. 9, p.312-356.

LUCCHESI, A. A. Processos fisiológicos da cultura da cana-de-açúcar (Saccharum spp). Piracicaba: ESALQ/USP, 1995. 50p.

LUCK, D. J.; RUBIN, S. Marketing research. 7. ed. New Delhi: Prentice Hall of India, 1987. 702p.

MAGALHÃES, P. S. G.; BRAUNBECK, O. A. Colheita de cana-de-açúcar verde: energia renovável para uma agricultura sustentável. http://server1.hypermart.net/agrobusiness/agroartigos/artigo9/index.html, out. 1998.

MARTINS, R. A.; COSTA NETO, P. L. O. Indicadores de desempenho para a gestão pela qualidade total: uma proposta de sistematização. Gestão \& Produção, v.5, n.3, p. 298-311, dez. 1998. 
MATTAR, F. N. Pesquisa de marketing II, São Paulo: Atlas, 1993. 224p.

MATTAR, F. N. Pesquisa de marketing I. 3. ed. São Paulo: Atlas, 1996. 344p.

MIALHE, L. G. Máquinas Agrícolas: ensaios \& certificação. Piracicaba: FEALQ, 1996. $722 p$.

MOREIRA, C. A.; MENEZES, J. F. O custo operacional da maquinaria agrícola. Atualidades agronômicas, v.1, n.1, p.38-48, fev./mar, 1973.

NUNES JÚNIOR., D.; PINTO, R. S. A.; KIL, R. A. Indicadores de desempenho da agroindústria canavieira - safra 97/98. Ribeirão Preto: IDEA, 1998. 119p.

NUNES JÚNIOR., D.; PINTO, R. S. A.; KIL, R. A. Indicadores de desempenho da agroindústria canavieira - safra 98/99. Ribeirão Preto: IDEA, 1999. 117p. NUNES JÚNIOR., D.; PINTO, R. S. A.; KIL, R. A. Indicadores de desempenho da agroindústria canavieira - safra 99/2000. Ribeirão Preto: IDEA, 2000. $118 p$.

PAIXÃO, M. No coração do canavial: estudo crítico do complexo agroindustrial sucroalcooleiro e das relações de trabalho na lavoura canavieira (estudo comparativo em doze Estados do Brasil). Rio de Janeiro, 1994. 176p. Dissertação (Mestrado) - Universidade Federal do Rio de Janeiro.

PINAZZA, L. A.; ALIMANDRO, R.; WEDEKIN, I. (Coord.) Agenda para a competitividade do agribusiness brasileiro. Rio de Janeiro: FGV; São Paulo: ABAG, 2001. 288p.

ROMANACH, L. M.; CARON, D. Emprego, trabalho, custo e mecanização da colheita da cana-de-açúcar. STAB. Açúcar, Álcool e Subprodutos. v17, n.5, p.25. maio/jun. 1999. 
SILVA, A. L. M. Indicadores de desempenho do transporte rodoviário de cargas. São Carlos, 1999. 121p. Dissertação (Mestrado) - Escola de Engenharia de São Carlos, Universidade de São Paulo.

SINK, D. S. The role of measurement in achieving world class quality and productivity management. Industrial Engineering, n.6, p.23-28, June 1991.

SINK, D. S.; TUTTLE, T. C. Planejamento e medição para a performance. Rio de Janeiro: Qualitymark, 1993. 212p.

TAKASHINA, N. T.; FLORES, M. C. X. Indicadores da qualidade e do desempenho - como estabelecer metas para medir resultados. São Paulo: Qualitymark, 1996. 100p.

TAKASHINA, N. T.; FLORES, M. C. Indicadores da Qualidade e Desempenho. Rio de Janeiro: Qualitymark Editora, 1997. 100p.

TAVARES, N. S. A. Gerenciamento do desempenho - um estudo de caso. Campinas, 2000. 158 p. Dissertação (Mestrado) - Faculdade de Engenharia Mecânica, Universidade Estadual de Campinas.

TRANSPORTE MODERNO. A frota brasileira e as mudanças. Transporte moderno. v.35, n.383, p.13, ago. 1997.

UNICA Informação UNICA. São Paulo: União das Agroindústrias Canavieiras de São Paulo, 2000. 8p.

RICHARDSON, A. J.; AMPT, E. S.; MEYBURG, A. H. Survey methods for transport planning. Melbourne: Eucalyptus Press. 1995. 291p.

RUMLER, G. A.; BRACHE, A. P. Melhores desempenhos das empresas. 2.ed., São Paulo: Makron Books, 1994. 313p. 
VALENTE, A. M.; PASSAGLIA, E.; NOVAES, A. G. Gerenciamento de Transporte e Frotas. São Paulo: Pioneira, 1997. 215 p. 


\section{APÊNDICES}




\section{APÊNDICE 1}

\section{PESQUISA SOBRE PRODUTIVIDADE AGRÍCOLA DO SETOR SUCROALCOOLEIRO - SAFRA $97 / 98$}

\section{NOME DA EMPRESA:}

\section{NOME DO COLABORADOR:}

Fone para contato: $\left[\begin{array}{ll}1 & \text { e-mail: }\end{array}\right.$

Preencha no interior dos quadrículos:

PRODUÇÃO AGROINDUSTRIAL:

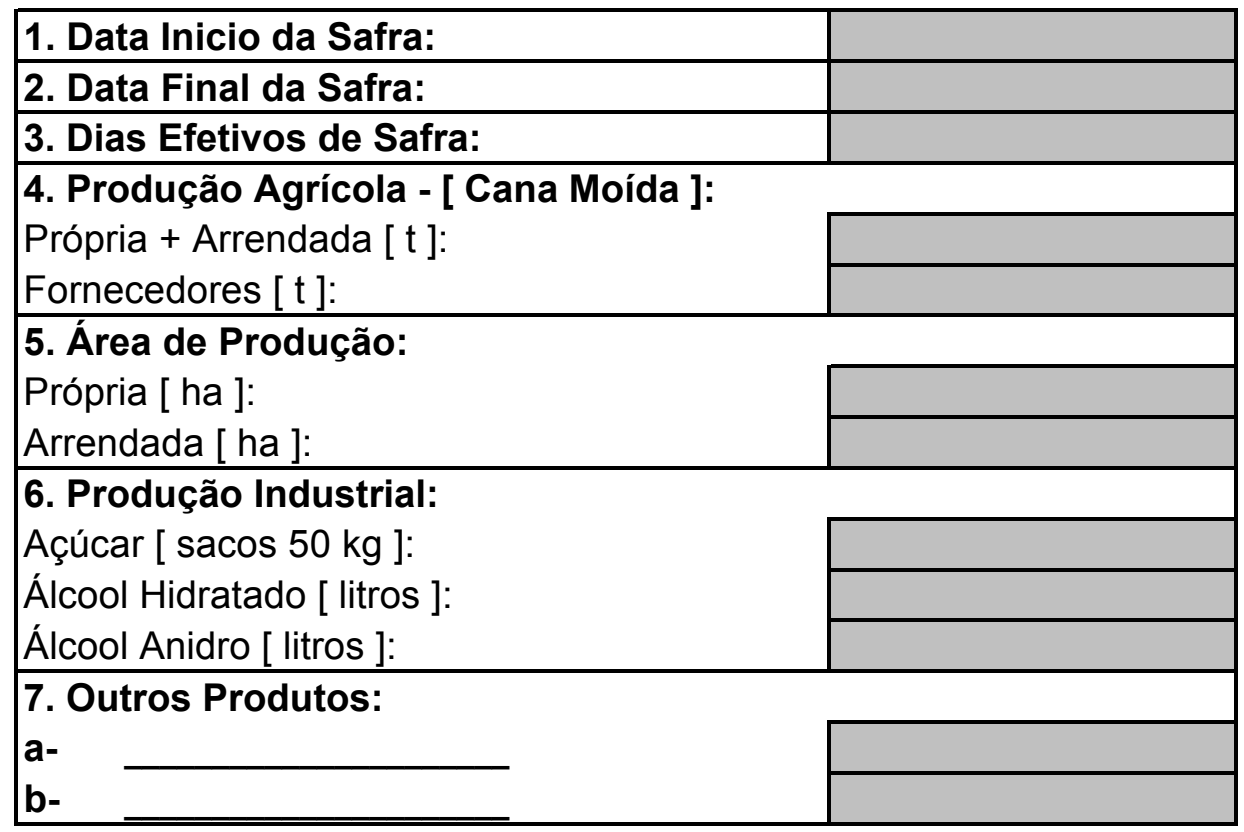

8. Área Plantada em 1997:

\begin{tabular}{|l|l|}
\hline \multicolumn{1}{|c|}{ Tipo } & Área [ ha ] \\
\hline Manual & \\
\hline Mecanizado & \\
\hline Total & \\
\hline Meiosi & \\
\hline
\end{tabular}

9. Projeção da Área de Plantio

Própria + Arrendada:

\begin{tabular}{|c|c|}
\hline Ano & Área [ ha ] \\
\hline 96 & \\
\hline 97 & \\
\hline 98 & \\
\hline
\end{tabular}

Obs: Cana comercial + viveiro.

QUALIDADE DA MATÉRIA-PRIMA:

\begin{tabular}{|l|l|}
\hline 10. Fibra \% Cana: & 11. PC \% Cana [ Média da Safra ]: \\
\hline 12. Tempo Médio de Queima [ horas ]: & 13. ATR Médio da Safra [ kg/t cana ]: \\
\hline
\end{tabular}

14. Precipitação Pluviométrica Mensal [ $\mathrm{mm}$ ]: 


\begin{tabular}{|l|l|l|l|l|l|l|l|}
\hline Mai/96 & Out/96 & Mar/97 & & Ago/97 & \\
\hline Jun/96 & & Nov/96 & & Abr/97 & & Set/97 & \\
\hline Jul/96 & & Dez/96 & & Mai/97 & & Out/97 & \\
\hline Ago/96 & Jan/97 & & Jun/97 & & Nov/97 & \\
\hline Set/96 & & Fev/97 & & Jul/97 & & Dez/97 & \\
\hline
\end{tabular}

15. PC \% Cana [ Médias Mensais ]:

\begin{tabular}{|c|c|c|c|c|c|c|c|c|}
\hline Abril & Maio & Junho & Julho & Agosto & Setembro & Outubro & Novembro & Dezembro \\
\hline & & & & & & & & \\
\hline
\end{tabular}

16.Variedades de cana PLANTADAS em 97:

17. Variedades de cana COLHIDAS em 97:

\begin{tabular}{|l|l|l|l|}
\hline Variedade & Área [ ha ] & Variedade & Área [ ha ] \\
\hline & & & \\
\hline & & & \\
\hline & & & \\
\hline & & & \\
\hline & & & \\
\hline & & & \\
\hline & & & \\
\hline & & & \\
\hline & & & \\
\hline & & & \\
\hline & & & \\
\hline & & & \\
\hline & & & \\
\hline & & Outras & \\
\hline Outras & & Total & \\
\hline
\end{tabular}

18. CORTE DE CANA:

\section{MANUAL}




\begin{tabular}{|l|l|l|l|l|l|l|}
\hline \multicolumn{1}{|c|}{ Tipo } & Área [ ha ] & \multirow{2}{*}{ Toneladas } & \multicolumn{2}{c|}{ Impurezas [ \% ] } & \multicolumn{2}{c|}{ Perdas na Colheita [ \% ] } \\
\cline { 5 - 7 } & & & Minerais & Vegetais & Cana Planta & Cana Soca \\
\hline Crua & & & & & & \\
\hline Queimada & & & & & & \\
\hline
\end{tabular}

\section{MECÂNICO}

\begin{tabular}{|l|l|l|l|l|l|l|}
\hline \multicolumn{1}{|c|}{ Tipo } & Área [ ha ] & \multirow{2}{*}{ Toneladas } & \multicolumn{2}{c|}{ Impurezas [ \% ] } & \multicolumn{2}{c|}{ Perdas na Colheita [ \% ] } \\
\cline { 5 - 7 } & & & Minerais & Vegetais & Cana Planta & Cana Soca \\
\hline Picada Queimada & & & & & & \\
\hline Picada Crua & & & & & & \\
\hline Inteira Queimada & & & & & & \\
\hline Inteira Crua & & & & & \\
\hline
\end{tabular}

OBS: Caso a empresa não possua os índices de impurezas em separado por tipo de cana, preencha apenas o quadro abaixo:

\begin{tabular}{|l|l|l|}
\hline Tipo de Corte & Impurezas Minerais [ \% ] & Impurezas Vegetais [ \% ] \\
\hline Manual & & \\
\hline Mecanizado & & \\
\hline
\end{tabular}

19. Área de Colheita [ Própria + Arrendada ] e Produtividades por Corte:

\begin{tabular}{|l|l|l|l|}
\hline \multicolumn{1}{|c|}{ Estágios } & Área [ ha ] & Produção [ t ] & TCH $^{* *}$ \\
\hline Cana Planta Ano & & & \\
\hline Cana Planta Ano e Meio & & & \\
\hline $2^{\circ}$ Corte & & & \\
\hline $3^{\circ}$ Corte & & & \\
\hline $4^{\circ}$ Corte & & & \\
\hline $5^{\circ}$ Corte & & & \\
\hline $6^{\circ}$ Corte & & & \\
\hline $7^{\circ}$ Corte & & & \\
\hline acima do $7^{\circ}$ Corte & & & \\
\hline Total & & & \\
\hline
\end{tabular}

** TCH - Média Ponderada de Tonelada de Cana por Hectare.

\section{Média TCH na Safra 98/99:}

20. Utilização de Maturadores em 1997:

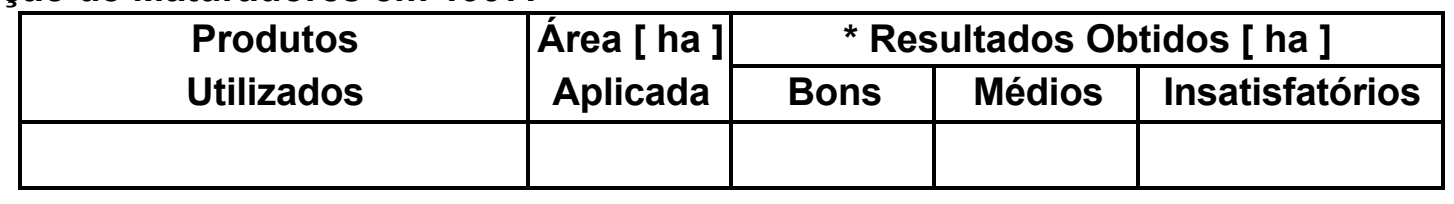




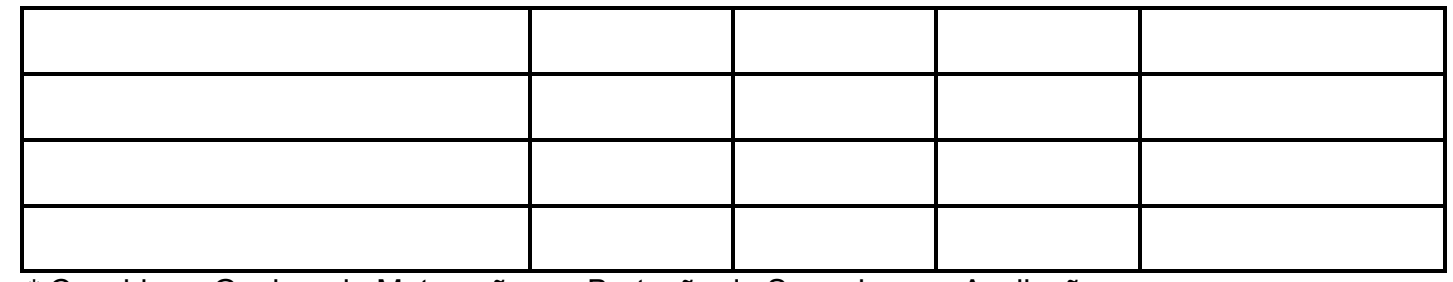

* Considerar Ganhos de Maturação e a Brotação de Soqueiras na Avaliação.

21. Corretivos e Adubação aplicados em 1997:

\begin{tabular}{|l|l|l|l|l|}
\hline \multirow{2}{*}{ Insumos } & \multicolumn{2}{c|}{ Plantio } & \multicolumn{2}{c|}{ Soqueira } \\
\cline { 2 - 5 } & Dose & Área [ ha ] & Dose & Área [ ha ] \\
\hline Calcário [ t/ha ] & & & & \\
\hline Gesso [ t/ha ] & & & & \\
\hline Torta Filtro [ t/ha ] & & & & \\
\hline Composto [ t/ha ] & & & & \\
\hline Vinhaça [ m $^{3} / \mathrm{ha}$ ] & & & & \\
\hline & & & & \\
\hline
\end{tabular}

\begin{tabular}{|c|c|c|}
\hline Adubo Químico [ Gasto Médio ] & Plantio & Soqueira \\
\hline $\mathrm{N}$ [ kg/ha ] & & \\
\hline $\mathrm{P}$ [ kg/ha ] & & \\
\hline $\mathrm{K}$ [ kg/ha ] & & \\
\hline Área sem adubo químico [ ha ] & & \\
\hline
\end{tabular}

22. Herbicidas utilizados em 1997:

\begin{tabular}{|l|cc|}
\hline Produtos ou Misturas de Produtos & Dosagens Médias [ litros ou kg/ha ] \\
\hline & \multicolumn{1}{|c|}{$+{ }^{-}$} & + \\
\hline & + & + \\
\hline & + & + \\
\hline & + & + \\
\hline & + & + \\
\hline & + & + \\
\hline
\end{tabular}

Quantidades de herbicidas utilizados em 1997:

\begin{tabular}{|c|c|}
\hline Produtos & Quantidades [ litros ou kg ] \\
\hline & \\
\hline & \\
\hline & \\
\hline
\end{tabular}




\begin{tabular}{|l|l|}
\hline & \\
\hline & \\
\hline & \\
\hline & \\
\hline
\end{tabular}

23. Inseticidas e Nematicidas utilizados em 1997:

\begin{tabular}{|c|cc|}
\hline Produtos ou Misturas de Produtos & \multicolumn{2}{|c|}{ Dosagens Médias [ litros ou kg/ha ] } \\
\hline & + & + \\
\hline & + & + \\
\hline & + & + \\
\hline
\end{tabular}

Quantidades utilizadas em 1997:

\begin{tabular}{|l|l|}
\hline Produtos & Quantidades [ litros ou kg ] \\
\hline & \\
\hline & \\
\hline & \\
\hline & \\
\hline
\end{tabular}

\section{DESEMPENHO DA MÃO-DE-OBRA RURAL:}

24. Corte de Cana [ $t$ / homem / dia ]:

26. N $^{\circ}$ Diárias Adicionais Gastas na Safra com Atividades de Apoio ${ }^{(1)}$ ao Corte de Cana:

28. N Diárias Gastas por Hectare no Plantio de 1997(incluindo o corte de mudas):
25. Índice de Absenteísmo no Corte Cana [ \% ]:

27. $N^{\circ}$ Diárias Gastas por Hectare com Serviços Gerais(2) em 1997:

29. N$^{\circ}$ Diárias Gastas por Hectare na Carpa 97: Carpa Manual:

Catação Química:

(1) Atividades de Apoio ao Corte de Cana referem-se à Catação de Bituca, Acerto/Amarrio de Cargas, Engate/Desengate de julietas, Fiscais etc.

(2) Serviços Gerais referem-se a Roguing, Cerca, Carregar Insumos, Jardinagem, Tratamento Térmico, Catação de Mato/Pedra etc.

30. Custo da Mão-de-Obra Rural:

Valor Médio pago por Diária com encargos sociais

Valor Médio pago no Corte de Cana com encargos sociais

( R\$ / Diária )

( $\mathrm{R} \$$ / tonelada )

31. Gasto com Transporte de Pessoal da Área Agrícola (rurículas,motoristas/operadores, fiscais e encarregados) no ano de 1997: 
32. Informações Gerais Sobre Custo* de Produção da Cana [ R\$ de Dez/97 ]:

\begin{tabular}{|l|l|l|l|l|l|}
\hline \multicolumn{2}{|c|}{ Custos } & Insumos & $\begin{array}{c}\text { Mecani- } \\
\text { zação }\end{array}$ & $\begin{array}{c}\text { Trans- } \\
\text { porte }\end{array}$ & $\begin{array}{c}\text { Mão-de- } \\
\text { Obra Rural }\end{array}$ \\
\hline Preparo de Solo & {$[R \$ / \mathrm{ha}]$} & & & & \\
\hline Plantio** & {$[\mathrm{R} \$ / \mathrm{ha}]$} & & & & \\
\hline Tratos Culturais Cana Planta & {$[\mathrm{R} \$ / \mathrm{ha}]$} & & & & \\
\hline Tratos Culturais Cana Soca & {$[\mathrm{R} \$ / \mathrm{ha}]$} & & & & \\
\hline Corte de Cana & {$[\mathrm{R} \$ / \mathrm{t}]$} & & & & \\
\hline Carregamento & {$[\mathrm{R} \$ / \mathrm{t}]$} & & & & \\
\hline Transporte & {$[\mathrm{R} \$ / \mathrm{t}]$} & & & & \\
\hline
\end{tabular}

** Na parcela de Insumos do Plantio, incluir o custo com mudas.

* Considerar depreciação dos equipamentos e encargos sociais e não considerar despesas financeiras. 


\section{APÊNDICE 2}

\section{PESQUISA SOBRE MECANIZAÇÃO, TRANSPORTE E MANUTENÇÃO DE FROTA DO SETOR SUCROALCOOLEIRO - SAFRA $97 / 98$}

\section{NOME DA EMPRESA:}

NOME DO COLABORADOR:

Fone para contato: e-mail:

Preencha no interior dos quadrículos:

\begin{tabular}{|l|l|}
\hline 1. Distância Média das Fazendas [ $\mathrm{km}]:$ & 2. $\mathrm{N}^{\circ}$ Médio de Frentes de Colheita: \\
\hline 3. Volume
\end{tabular}

3. Volume Total de Diesel Gasto em 1997 com Frota Própria [ litros ]:

4. Volume Total de Óleo Motor Gasto em 1997 com Frota Própria a Diesel [ litros ]:

5. Volume de Diesel Gasto em 1997 com Carregadoras de Cana [ litros ]:

6. Volume de Óleo Hidráulico Gasto em 1997 com Carregadoras de Cana [ litros ]:

\section{Volume de Diesel Gasto em 1997 com Colhe-} doras de Cana [ litros ]:

8. Volume de Óleo Hidráulico Gasto em 1997 com Colhedoras de Cana [ litros ]:

9. Total de Retíficas de Motores em 1997:

10. Total de Pneus Novos Comprados 1997:

11. Total de Pneus Reformados em 1997:

12. Gasto Total com RM da frota - 1997 [R\$]:

Obs: Item 12 - Gasto com RM (Reparos e Manutenção) da Frota Motorizada abrange os gastos totais com Compra de Peças e Serviços de Terceiros (incluem-se compras de pneus e suas reformas externas), Peças Próprias ( do almoxarifado) e Mão-de-Obra Própria da Manutenção ( incluindo seus encargos sociais ). Nota: Dados referentes ao ano 1997 no período de Janeiro a Dezembro.

\section{APLICAÇÃO DE VINHAÇA:}

\begin{tabular}{|l|c|c|c|}
\hline \multirow{2}{*}{ Tipo } & \multicolumn{2}{|c|}{ Equipamentos } & $\begin{array}{c}\text { Área } \\
\text { Aplicada [ ha ] }\end{array}$ \\
\hline & Próprios [ $\left.\mathrm{m}^{3}\right]$ & Terceiros [ $\left.\mathrm{m}^{3}\right]$ & \\
\hline Aspersão de Canais & & & \\
\hline Rolão de canais & & & \\
\hline Caminhão Solteiro & & & \\
\hline Cam. Romeu e Julieta & & & \\
\hline Cam. Solteiro + Rolão & & & \\
\hline Cam. Romeu/Julieta + Rolão & & & \\
\hline Misto ( ) & & & \\
\hline
\end{tabular}

14. CARREGAMENTO DE CANA: 


\begin{tabular}{|c|c|c|c|}
\hline Capacidade da Carregadora & Propriedade & $\mathbf{N}^{\mathbf{0}}$ de Equipamentos & Toneladas \\
\hline \multirow{2}{*}{$(400 \mathrm{~kg})$} & Próprio & & \\
\hline & Terceiros & & \\
\hline \multirow{2}{*}{$\mathrm{kg})$} & Próprio & & \\
\hline & Terceiros & & \\
\hline \multirow{2}{*}{$(\mathrm{kg})$} & Próprio & & \\
\hline & Terceiros & & \\
\hline Veículos de Transbordo & Próprio & & \\
\hline
\end{tabular}

\section{TRANSPORTE DE CANA:}

\begin{tabular}{|c|c|c|c|c|c|c|}
\hline $\begin{array}{l}\text { Classe de } \\
\text { Caminhão }\end{array}$ & Propriedade & $\begin{array}{c}\mathbf{N}^{\circ} \\
\text { Caminhões }\end{array}$ & $\begin{array}{c}\text { Toneladas } \\
\text { Transportadas }\end{array}$ & $\begin{array}{c}\mathbf{N}^{\circ} \\
\text { Julietas }\end{array}$ & $\begin{array}{c}\text { N}^{\circ} \text { Semi- } \\
\text { Reboques }\end{array}$ & $\begin{array}{c}\mathbf{N}^{\circ} \\
\text { Dolly }\end{array}$ \\
\hline \multirow[t]{2}{*}{ Solteiro } & Próprio & & & & & \\
\hline & Terceiros & & & & & \\
\hline \multirow[t]{2}{*}{ Romeu e Julieta } & Próprio & & & & & \\
\hline & Terceiros & & & & & \\
\hline \multirow[t]{2}{*}{ Treminhão } & Próprio & & & & & \\
\hline & Terceiros & & & & & \\
\hline \multirow{4}{*}{$\begin{array}{c}\text { Rodotrem } \\
\text { (cavalo mecân.) }\end{array}$} & Próprio & & & & & \\
\hline & Terceiros & & & & & \\
\hline & Próprio & & & & & \\
\hline & Terceiros & & & & & \\
\hline
\end{tabular}

16. VALOR PAGO A TERCEIROS NO CARREGAMENTO DE CANA E REBOQUE (Puxe) DE JULIETAS:

\begin{tabular}{|l|l|}
\hline Carregamento $-[R \$ / t]$ & Reboque ( puxe ) $-[R$ / t ] \\
\hline & \\
\hline
\end{tabular}

17. VALOR DO FRETE PAGO A TERCEIROS* :

\begin{tabular}{|l|l|l|}
\hline Distância Campo-Indústria & $\begin{array}{c}\text { Valor pago por tonelada } \\
{[\mathrm{R} \$ / \mathrm{t}]-}\end{array}$ & $\begin{array}{c}\text { Valor pago por tonelada } \\
{[\mathrm{R} \$ / \mathrm{t}]-}\end{array}$ \\
\hline
\end{tabular}




\begin{tabular}{|l|l|l|}
\hline de 0 a $4,9 \mathrm{~km}$ & & \\
\hline de 5 a $9,9 \mathrm{~km}$ & & \\
\hline de 10 a $14,9 \mathrm{~km}$ & & \\
\hline de 15 a $19,9 \mathrm{~km}$ & & \\
\hline de 20 a $24,9 \mathrm{~km}$ & & \\
\hline de 25 a $29,9 \mathrm{~km}$ & & \\
\hline de 30 a $34,9 \mathrm{~km}$ & & \\
\hline de 35 a $39,9 \mathrm{~km}$ & & \\
\hline de 40 a $44,9 \mathrm{~km}$ & & \\
\hline de 50 a $54,9 \mathrm{~km}$ & & \\
\hline de 55 a $59,9 \mathrm{~km}$ & & \\
\hline de 60 a $64,9 \mathrm{~km}$ & & \\
\hline de 65 a $70 \mathrm{~km}$ & & \\
\hline acima de $70 \mathrm{~km}$ & & \\
\hline
\end{tabular}

${ }^{*}$ A segunda coluna de valores de frete atende às empresas que possuem 2 tabelas de frete, uma para cada modalidade de transporte (por exemplo, caminhão solteiro e biminhão). Neste caso, especifique as modalidades de transporte nos cabeçalhos sublinhados das colunas. A empresa que possuir tabela única só deve preencher a primeira coluna.

\section{MÃO-DE-OBRA DIRETA DA MANUTENÇÃO DA FROTA:}

\begin{tabular}{|l|l|l|l|l|}
\hline \multirow{2}{*}{ Função } & \multicolumn{2}{|c|}{$\mathbf{N}^{\circ}$ Funcion. Efetivos } & \multicolumn{2}{l|}{$\mathbf{N}^{0}$ Médio Funcionários Terceirizados" } \\
\hline & Safra & Entressafra & Safra & Entressafra \\
\hline Mecânico-Líder & & & & \\
\hline Mecânico & & & & \\
\hline Bombista & & & & \\
\hline Auxiliar & & & & \\
\hline Torneiro & & & & \\
\hline Eletricista & & & & \\
\hline Soldador & & & & \\
\hline Lubrificador & & & & \\
\hline Ferramenteiro & & & & \\
\hline Lavador & & & & \\
\hline Frentista & & & & \\
\hline Comboísta & & & & \\
\hline Borracheiro & & & & \\
\hline Funileiro & & & & \\
\hline Pintor & & & & \\
\hline Faxineiro & & & & \\
\hline \hline
\end{tabular}

\section{MÃO-DE-OBRA INDIRETA DA MANUTENÇÃO DA FROTA:}

\begin{tabular}{|l|l|l|}
\hline Função & $\mathbf{N}^{\circ}$ Funcionários na Safra & $\mathbf{N}^{\circ}$ Funcionários na Entressafra \\
\hline Gerente & & \\
\hline Chefe & & \\
\hline Encarregado & & \\
\hline
\end{tabular}




\begin{tabular}{|l|l|l|}
\hline Supervisor & & \\
\hline Controlador & & \\
\hline Almoxarife & & \\
\hline Auxiliar de Escritório & & \\
\hline Secretária & & \\
\hline Digitador & & \\
\hline Apontador & & \\
\hline & & \\
\hline
\end{tabular}

\section{DISPONILIDADE MECÂNICA DOS EQUIPAMENTOS MOTORIZADOS PRÓPRIOS:}

Aponte o total de horas de permanência na oficina mecânica dos equipamentos motorizados relacionados com o Transporte, Corte Mecanizado e Carregamento de Cana no período de safra de 1997, independente da jornada de trabalho da oficina.

\begin{tabular}{|l|l|l|}
\hline Tipo & Qtde Equiptos & Total de Horas de Permanência na Oficina \\
\hline Caminhões Canavieiros & & \\
\hline Colhedoras de Cana & & \\
\hline Tratores de Reboque & & \\
\hline Carregadoras de Cana & & \\
\hline
\end{tabular}

Obs: Considerar também como tempo de permanência as intervenções de Lavagem/Lubrificação, Borracharia, Socorro no Campo, Manutenção Externa etc. O período de safra se encontra no questionário de PRODUTIVIDADE AGRICOLA.

\section{RELAÇÃO DE EQUIPAMENTOS MOTORIZADOS PERTENCENTES À EMPRESA:}

Neste item, solicitamos que a frota pertencente à empresa seja relacionada, distribuída por: Tipo, Modelo, Ano de Fabricação, Quantidade e Total, conforme o exemplo abaixo:

\begin{tabular}{llccc|}
\hline TIPO & MODELO & ANO DE & QTDE & TOTAL \\
& & FABRICAÇÃo & & \\
\hline Caminhão Canavieiro & MB 2219 & 1983 & 15 & \\
& MB 2213 & 1975 & 5 & \\
& VOLVO 360 & 1996 & 3 & $\mathbf{2 3}$ \\
\hline Caminhão de Vinhaça & CHEVROLET D60 & 1982 & 3 & $\mathbf{3}$ \\
\hline Trator de Pneus & MF 296 4x4 & 1984 & 2 & \\
& MF 275 & 1987 & 1 & $\mathbf{3}$ \\
\hline Trator de Esteiras & CATERPILLAR D6 SA & 1991 & 2 & $\mathbf{2}$ \\
\hline TOTAL GERAL & & & & $\mathbf{3 1}$ \\
\hline
\end{tabular}

Obs.: Os TIPOS de equipamentos motorizados comumente existentes nas empresas são:

- Caminhão Canavieiro

- Caminhão de Vinhaça

- Caminhão Pipa (de água)

- Caminhão Oficina

- Caminhão Comboio (abastec./lubr.)

- Caminhão Carga Seca

- Caminhão Distribuidor de Calcário
- Caminhão Prancha

- Caminhão Munck

- Caminhão Bombeiro

- Caminhão de Turma

- Camioneta

- Ônibus

- Motocicleta
- Pá-carregadora

- Colhedora de Cana

- Colhedora de Cereais

- Motoniveladora

- Rolo Compactador

- Retroescavadora

- Trator Amostrador Cana 
- Caminhão Distribuidor Torta de Filtro

- Caminhão Basculante

- Utilitário (inclusive veíc. passeio)
- Trator de Pneus

- Trator de Esteiras

- Carregadora de Cana
- Trator Trâmpulo

- Motobomba

- Motor Estacionário

22. RELAÇĀO DE EQUIPAMENTOS MOTORIZADOS ALUGADOS:

Neste item, solicitamos que a frota alugada pela empresa seja relacionada, distribuída por Tipo, Quantidade Alugada na Safra e Quantidade Alugada na Entressafra, conforme o exemplo abaixo:

\begin{tabular}{|c|c|c|c|}
\hline \multirow[t]{2}{*}{ Tipo } & \multirow[t]{2}{*}{ MODELO } & \multicolumn{2}{|c|}{ Quantidade Alugada } \\
\hline & & Safra & Entressafra \\
\hline \multirow[t]{3}{*}{ Caminhão Canavieiro } & FORD 22000 & 0 & 4 \\
\hline & MB 2213 & 1 & 0 \\
\hline & VOLVO 340 & 2 & 0 \\
\hline Caminhão de Vinhaça & MB 2213 & 6 & 0 \\
\hline \multirow[t]{2}{*}{ Trator de Pneus } & VALMET 148-4 & 4 & 7 \\
\hline & FORD 8830 & 2 & 6 \\
\hline \multicolumn{2}{|c|}{ TOTAL GERAL } & 15 & 17 \\
\hline
\end{tabular}

Resposta do item - 22:

\begin{tabular}{|c|c|c|c|}
\hline \multirow[t]{2}{*}{ Tipo } & \multirow[t]{2}{*}{ MODELO } & \multicolumn{2}{|c|}{ Quantidade Alugada } \\
\hline & & Safra & Entressafra \\
\hline & & & \\
\hline & & & \\
\hline & & & \\
\hline & & & \\
\hline & & & \\
\hline & & & \\
\hline & & & \\
\hline & & & \\
\hline & & & \\
\hline & & & \\
\hline & & & \\
\hline & & & \\
\hline & & & \\
\hline & & & \\
\hline & & & \\
\hline & & & \\
\hline & TO & & \\
\hline
\end{tabular}

